Historic, Archive Document

Do not assume content reflects current scientific knowledge, policies, or practices. 



\section{HEDGE LAWN NURSERY}

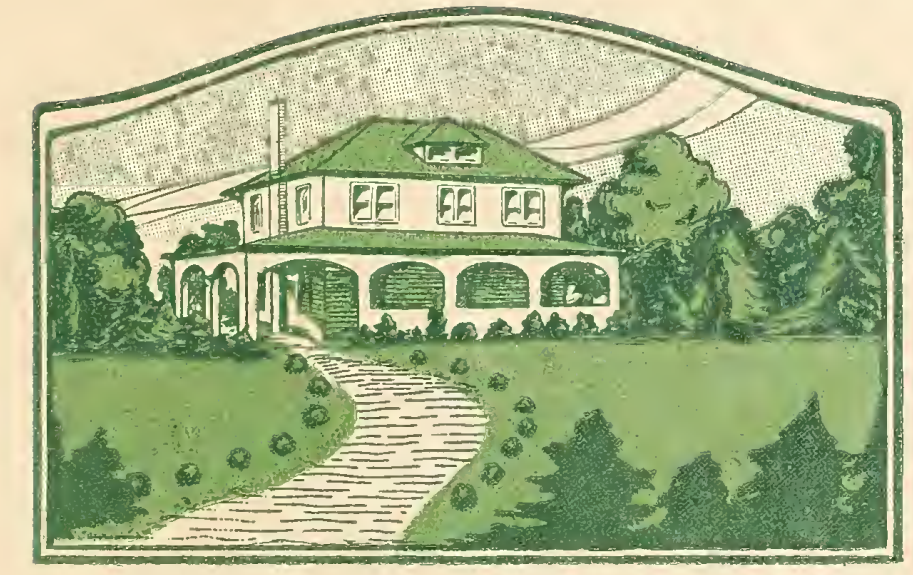

ROANOKE - - VIRGINIA 


\section{TO OUR FRIENDS}

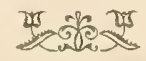

\section{We hope that this little edition fulfills its mission-and that is to make your place more beautiful and more fruitful}

We have tried to make it more than a mere catalogue. In it you will find described many treasures of the orchard and garden. In our extensive assortment of trees, shrubs and flowers and with so many varieties from which to choose, there are plants available for any place and for any purpose for which you may need them. Their commercial value is undisputed. Of their beauty can it truly be said-in their manner is grace, in their color is rest and their power of beauty gives happiness. When you know them intimately their presence is inspiring and their influence perpetual.

For your convenience we have made this book into Ornamental and Fruit Departments. These are properly divided into several groups and under each group heading we first describe, then suggest, planting and after care. Further information may be had by referring to index, and reading general topics, like Landscaping, How to Plan an Orchard, Spraying, Planting Instructions, etc. This may save you the trouble of writing, but if you fail to find what you want, remember we are obligated to every customer as well as the community for their friendship and patronage and we will gladly help you if we can.

We cherish a hope that this book will prove interesting and that somewhere in it you may find a helpful suggestion or new idea. It has been planned to assist you in making your place more bountiful, your house a home and your lot a beauty spot.

We cordially invite you to inspect our nursery.

Sincerely yours,

\section{HEDGE LAWN NURSERY}

WILLIAMSON ROAD

ROANOKE, VIRGINIA 


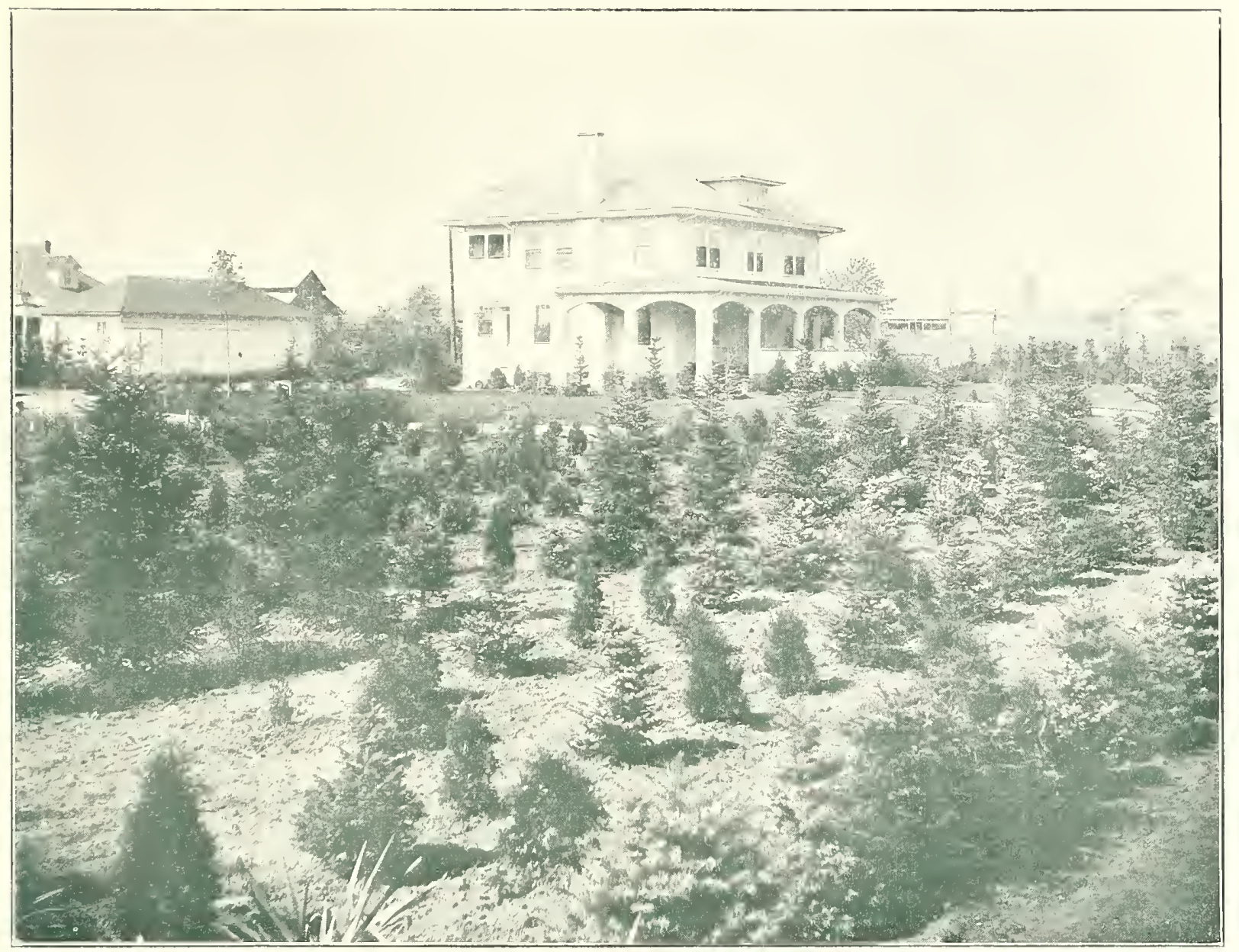

IEDGE LAWN NLRSERI--SHOWING A SAILL SECTION OF EVERGREENS

\section{HEDGE LAWN NURSERY \\ ROANOKE, VIRGINIA}

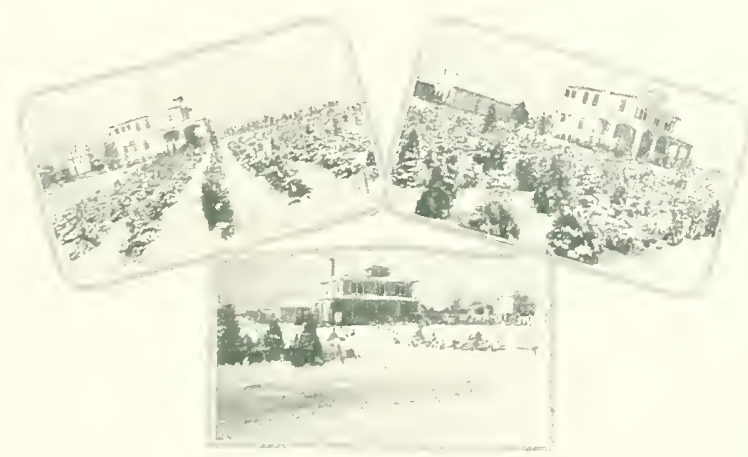




\section{OUR POLICIES AND SERVICE}

\section{READ BEFORE ORDERING}

Adjustments-Our chief aim is delivering to our customers-to you-a full measure of satisfaction, and any errors made in filling orders will be promptly and cheerfully corrected.

It is on this foundation that we have built our business and solicit your patronage. The cooperation we ask of you in establishing satisfaction is that you advise us immediately should an examination of your shipment disclose an error. Delays often make satisfactory adjustments impossible.

We have but few misunderstandings and believe that any differences which might arise in your dealings with us can be amicably straightened out.

In selling direct, without the expense of agents' commissions, we are enabled to give our customers a better value of goods and greater satisfaction.

Replacements-Everything that is humanly possible is done to insure the receipt by our customers of live, healthy stock that will thrive and give fine results if properly cared for.

The digging of stock, that is cutting roots and moving the plants from one place to another, has in it a certain amount of risk as does a surgical operation. Nursery stock is perishable in nature, for the plants we sell are living things. In the transplanting of them a few may die.

Ninety per cent. of failures are due to causes which you will readily recognize are beyond our control, such as delay in transit, improper care after receiving, undue exposture during planting, improper setting, failure to prune, impoverished or unadapted soil, disease and injury with lack of subsequent care and attention. Not only do we carefully pack and ship healthy live stock, but we instruct our customers as to the correct handling, planting and carme for the nursery stock they receive. Regardless of our many precautions a combination of the above circumstances may cause a tree to die although it possessed vigor and vitality when shipped.

Every bit of thought and knowledge we possess goes into the growing of our plants for a period sometime's from two to fifteen years. It has cost us just as much to raise those that fail as it does those that grow. In view of our nominal prices and the fact that only live healthy stock, properly prepared

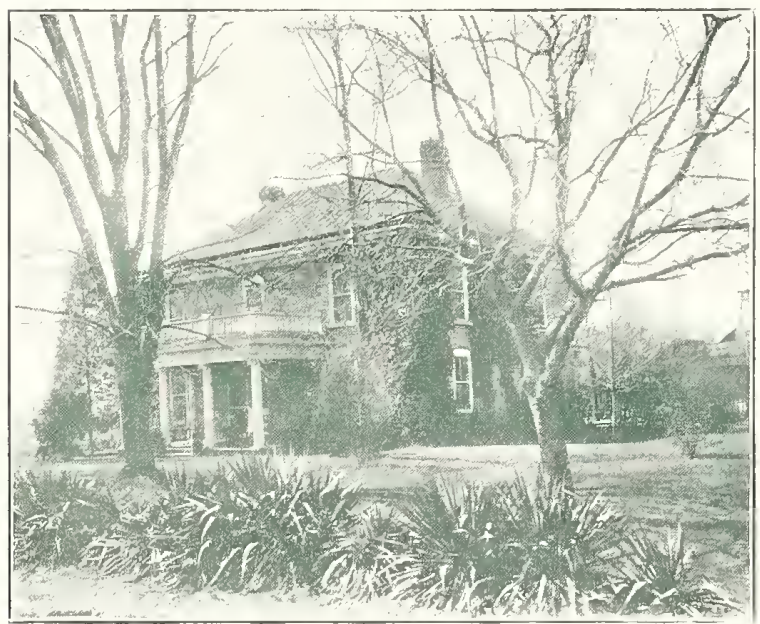

OUR OLD IHOME-NOTE YUCCA FILIMENTOSA IN FOREGROUND, ENGLISII IVY ON IIOUSE, RESULTS OF LANDSCAPING AND PLANTING FOURTEEN YEARS AGO for shipment, leave our nursery, replacements without charge are not possible.

Guarantee-All stock sent out by us must not only be healthy but true to labelled name and as described in this catalogue.

Errors, of course, sometimes occur. We pride ourselves on conducting our business on the highest ethical lines. We deplore misrepresentation and carelessness alike, and the fact that our business is singularly free of adjustments speaks for the consistently satisfying service we render our customers.

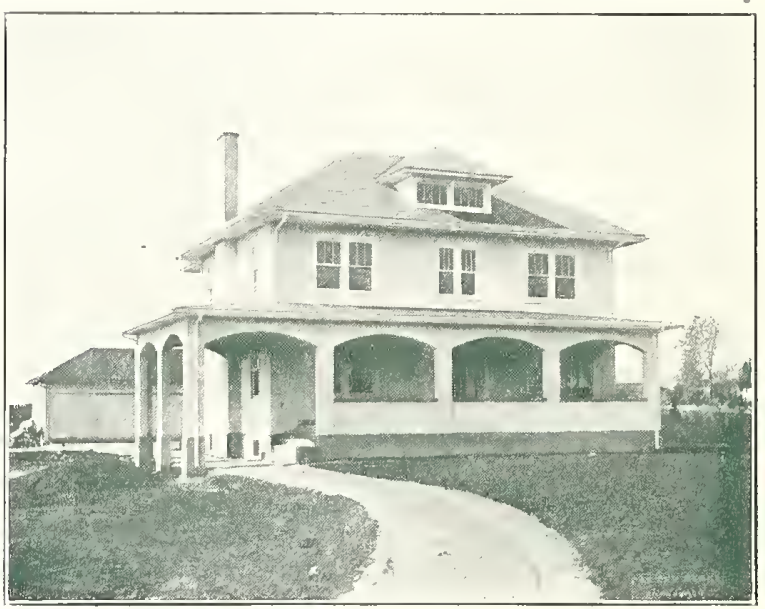

BEFORE PLANTING

Should, by any chance, a plant be found untrue to name we will gladly replace with the genuine or refund the purchase price. Beyond this we can assume no responsibility.

Substitution-Occasionally we find ourselves out of a certain variety. In such cases we always send the nearest match in color and season unless you instruct us, when placing the order, to make no substitution.

On many orders for fruits or ornamentals our intimate knowledge of varieties, soils and climate enable us to make changes which are profitable to our customers. We make no effort, however, to better a selection of varieties unless our customer gives us specific permission to do so

Terms-Unlike most types of business, the average turnover of our stock is four and a half years. In other words, we are that length of time in getting our money back even when the goods are sold on a cash basis. For this reason our terms are cash with order.

\section{When To Plant}

When is the best time to plant? This question is asked more than any other. There is no best time. Several conditions make it impossible to name either spring or fall. The best time to plant hardy things is when your soil is in the best condition to receive the plants. This preparation is the most necessary. The temperature of the ground changes little, fall or spring, after you get under the surface a few inches. All things being equal, fall has advantages over spring. The cut roots heal over during the winter, the rams usually 
firm the soil about the plant and with the first breath of spring air, your tree is on your grounds ready to start. But the spring planter doesn't have to risk winter injury on the tender plants; he has the long winter evenings to plan his requirements and the soil is usually a little easier to dig and prepare.

A State certificate of inspection accompanies each shipment, assuring its freedom from insect pests and disease. We are members of the American Association of Nurserymen.

\section{Brief Planting Instructions}

We send out planting instructions with each order. Some cultural hints are given under each

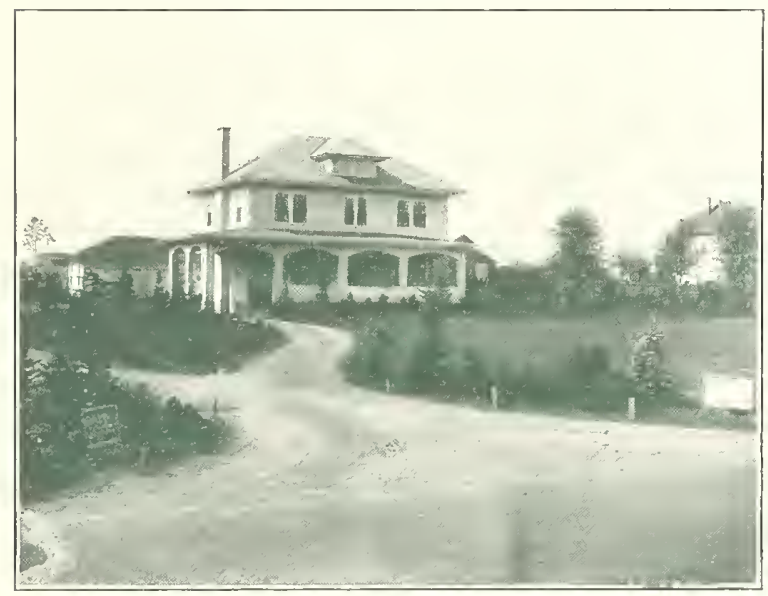

AFTER PLANTING

heading throughout the catalogue. Briefly, this is what you should do:

On arrival of trees, place in a protected place, keeping moist if held for a day only, else bury roots in ground at once.

Fruning is necessary. General rule is to cut off one-half to two-thirds the length of the lateral branches. This balances loss of root system necessary in digging the tree. Remove all label wires.

Plant carefully. Dig ample holes to take roots without crowding. Plant not more than an inch or two deeper than they formerly stood. Work fine soil into the roots, be sure there are no air pockets and tamp earth solid to insure contact with every root. Water, if possible, before applying the top three inches.

Mulching or cultivation is necessary if good growth is expected. Both conserve the moisture, which is very essential.

Watering, sprinkling and spraying are of little value during times of drought. Remember the roots of most plants are buried eight to eighteen inches in the soil and it takes a good soaking to reach them. Let the hose run slowly for an hour or so-it pays.

\section{Let Us Solve Your Landscape Problems}

Have you hesitated about beautifying your lawn because you hardly knew how to go about it? The proper selection and arrangement of plants in some cases does take more time and study than some busy folks can find to give to the subject. Just what plants to use to screen your (or your neighbor's) clothes yard from the house; to give your lawn seclusion; to relieve the bare look of the house foundation-these are among the problems that, perhaps, confront you. We have endeavored to make this book as helpful as possible and we feel confident the lists, descriptive matter and illustrations will point the way to the solution of many problems. Some, however, cannot be dealt with in generalities.

For the solution of individual problems we maintain men well trained in plant adaptabilities and arrangements. They will gladly give you our ideas on plant selections and arrangements, together with estimate of cost. This is done in either of two ways:

Personal calls to go over the problem right on the lawn or Letter Aid Service is offered to patron at more distant points. Through it we are able to give you much the same service as is rendered through a personal call, for with a detailed description of your problem, a sketch showing dimensions and existing features and a photo or two, if available, we can readily visualize it, and give you our ideas and estimate.

\section{The Secrets of Successful Landscape Gardening}

Start out with a definite object in view and plan accordingly.

Locate your walks and roadways, arranging them for service and beauty.

Avoid straight lines and sharp angles if possible. Graceful curves are more pleasing to the eye.

Plan to leave the center of lawn unobstructed. planting the borders with masses of shrubs and trees.

Remember, in arranging your shade trees on the lawn, your idea should not be to play checkers with them but to "frame" the house and not hide it. Always leave the center open as it makes the approach more inviting.

Background, or sky line, is a feature not half appreciated. Given a proper setting a cottage will

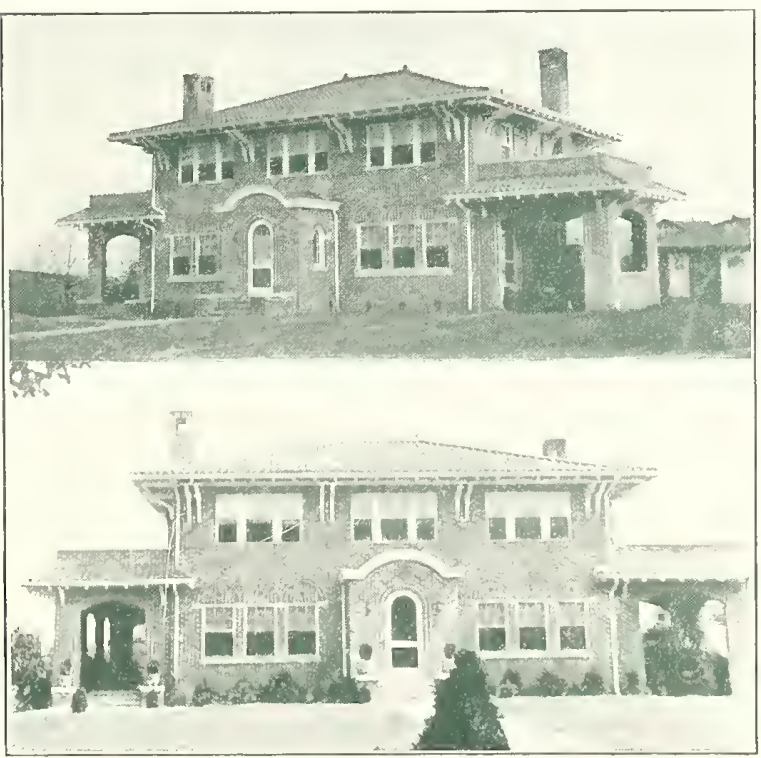

RESIDENCE OF M. F, RING, 502 GRANDIN ROAD, RALEIGH COURT, BEFORE AND AFTER PL.ANTING BY IIEDGE LAWN NURSERY. 
often be more attractive than a poorly planted mansion. Plant heavily behind and to the rear sides of your lome if on a big lawn.

Avoid too much rariety in mass planting. Alternating or "salt and pepper" arrangement is not nearly so effective as grouping plants of each kind. Where -pace permits at least five plants of a single kind is sliggested.

For front line or border planting especially, choose few varieties and plant more of them. The result will be more pleasing. Plant the taller things in the back of the border with the lower growing niles alternating and the horder plants in curves or groups.

For the foundation renember always-height in the corners, immediately 111 front of pillars and at the bare wall spaces. Under the windlows low or medium plants only.

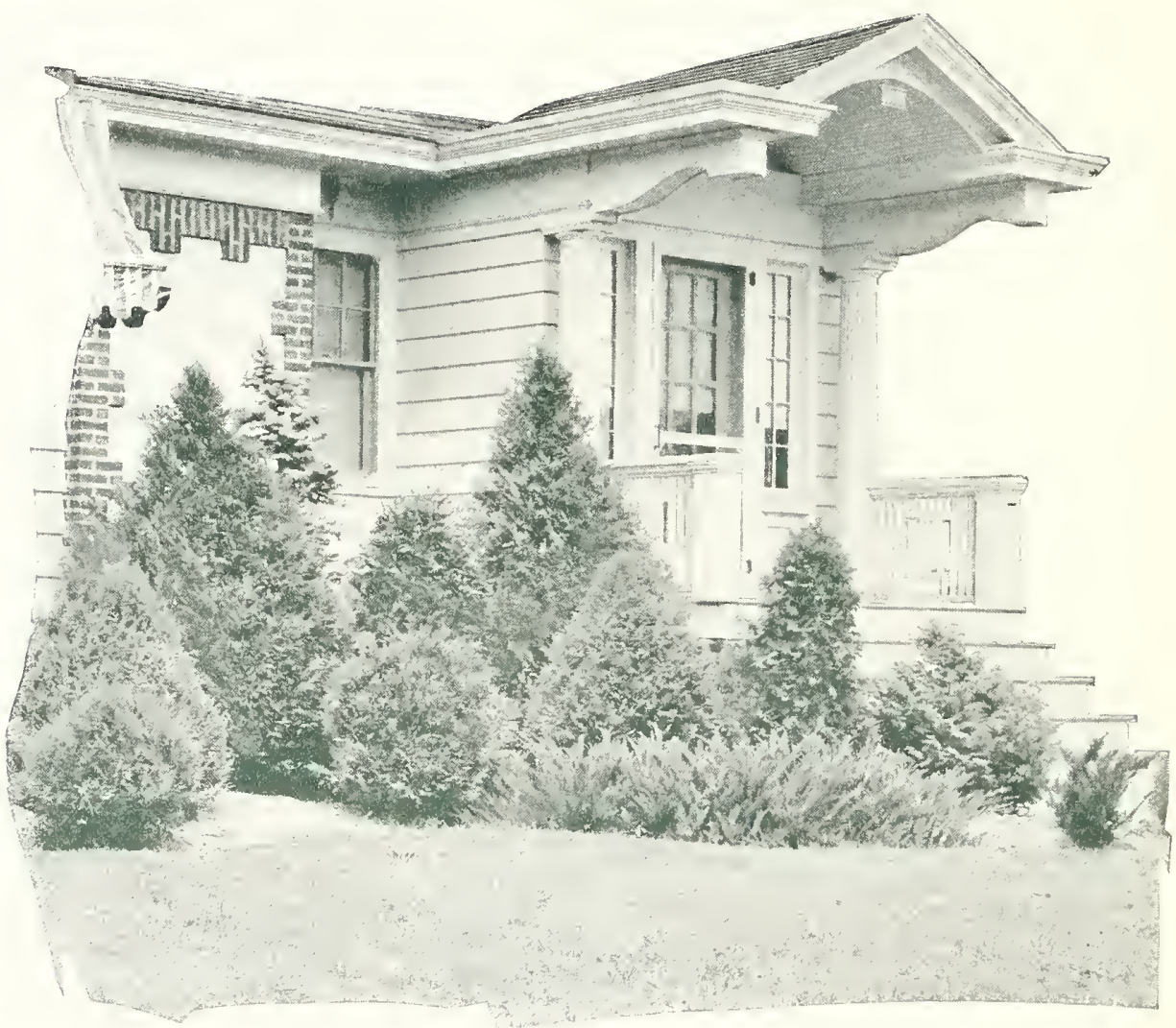

AN ITTRACTIVE FOLNDITION PLINTING OF EVERGREENS

\section{ROANOKE CITY MILLS}

MILLERS OF

\section{HIGH GRADE FLOUR, MEAL AND FEED}

Roanoke, Va., January 8, 1925

Hedge Lawn Nursery,

Roanoke, Virginia

Gentlemen:

I am writing to thank you for the very efficient and satisfactory work you did at my residence in dressing up my lawn and furnishing and planting mv evergreens. I have gotten a great many compliments on the nice appearance of the evergreens and an glad to say that I have not lost any of them. They are growing nicely and the arrangement is entirely satisfactory in every way.

It is possible that I will need a few more plants a little later on, and if so I assure you I will give you this business, as I am confident that the work I will get from you will please me.

Again thanking you for this work, I am

$$
\text { Yours very truly, }
$$

M. F. Ring, Vice President.

Roanoke City Mills. 


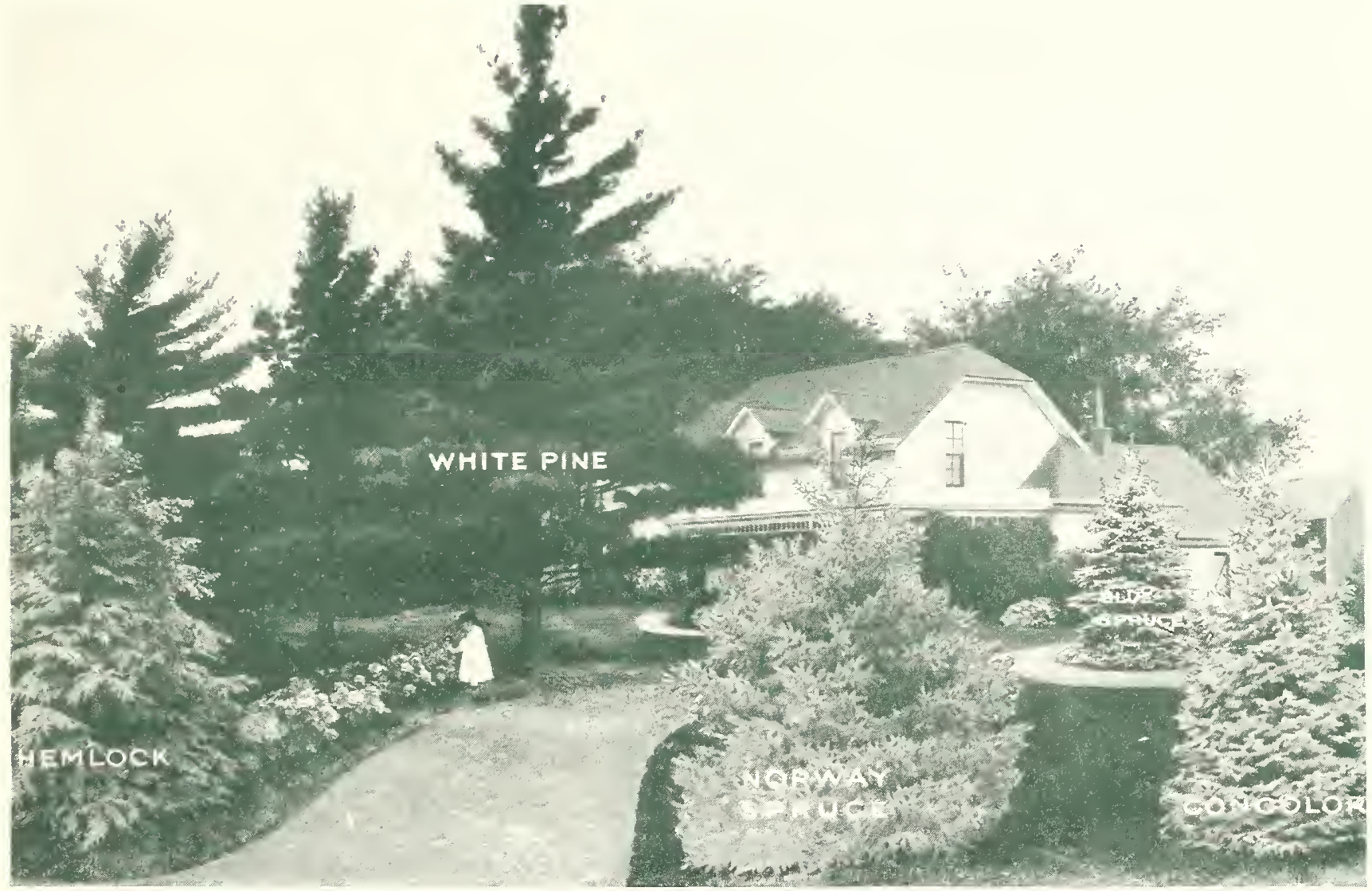

\section{EVERGREENS}

\section{ARE IMPORTANT IN ANY PLANTING}

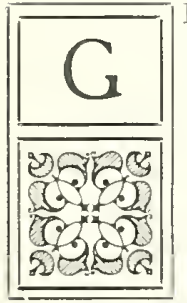

REEN of every shade and hue, charmingly contrasted with blue, gold and gray, their foliage is always pleasing. Pyramidal or erect, globular or spread. ing, you can find forms for every fancy. For groups or screening, in shelter planting or hedges you have nothing quite to equal them. In summer they are attractive, in winter they offer a conforting note to the bleak landscape and under the weight of ice and snow their great drooping branches of green seem to cheer.

Out in the lawn, the larger growing Pines, Spruces and Hemlocks suggest a permanency and a grandeur that cannot be duplicated with other planting materials. For small premises there are appropriate varieties. As backgrounds, hedges and specimens you will find plants suitable for every use. In landscape work they simply have no rivals. They are so wonderful because of their beauty throughout the four seasons of the year.

Their most popular use, of course, is for doorstep or foundation planting. No home is now complete without something to break the bare walls or soften the harsh lines. The day of cannas is past, persons demand something more permanent and more lasting than a few weeks of summer blossom and foliage. Evergreens fill every requirement. They are hardy, they are enduring and their beauty permanent. Their habits of growth, their various forms and interesting foliage enable any one to choose, no matter how fastidious, varieties that will be pleasing in effect and congenial of location.

\section{Planting Suggestions}

Before you dig your holes or loosen the burlap as all evergreens should be handled with balls of soil intact) set them up in arrangement as planned and move them about, view them from different angles so as to get the very best effect. When planting, the burlap should be loosened and laid down in the hole or removed or if the ball of soi is broken then the hole should be partially filled with earth and then the top portion of the burlap cut away with a sharp knife. By all means tread the soil firmly about the roots. The general planting directions also apply here. Watering is very necessary during periods of drought and especially the first year. Remember the caution to water copiously these deeply set plants-and one good soaking is worth a dozen light sprinklings.

\section{Pruning}

At planting time evergreens seldom need pruning. If well grown like ours they are shapely and when 
handled with balls of soil they should grow off without trouble. However, in a year or so some varieties are inclined to grow "open." Then shearing may be done with hedge tools, clipping the young growth, preferably not further than that made the previous season. This causes the inner branches to advance, making a very close and compact plant. thus hiding the unsightly interior of open trees.

\section{Important}

Prune evergreens when they are growing-better just as the spring growth comes on and at least before it be comes hard in July.

The principal trouble is the dog. Tie up the pup, as canines and connter don't mix, or else plant something on the front row in protection.

\section{The Arbor Vitae}

ARBOR VITAE A M E R I C A N, Thuja occidentalis. One of the most popular evergreens because of it easiness to transplant. growing kindly under adverse conditions, and as a specimen or hedge plant it is very attractive. It is inclined to be conical in habit of growth and while it is not as green in color during the winter as some of the other varieties it is one of the most popular because of its many good qualities.

ARBOR VITAE, $B$ E R K M A N GOLDEN, T. orientalis aurea nana. This is without doubt the showiest of all the Arbor Vitae family. The color is an unusually attractive bright green and is striking in appearance. Does especially well with us and should be in every plant$111 \mathrm{~g}$.

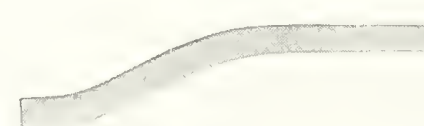

ARBOR VITAE, GLOBE, T. occidentalis globosa.

This usually develops into a perfect globe shape plant, the spread equalling the height. The foliage is light green and attractive. These are largely used for front line planting, as specimens in urns

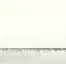

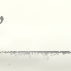
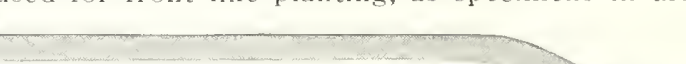


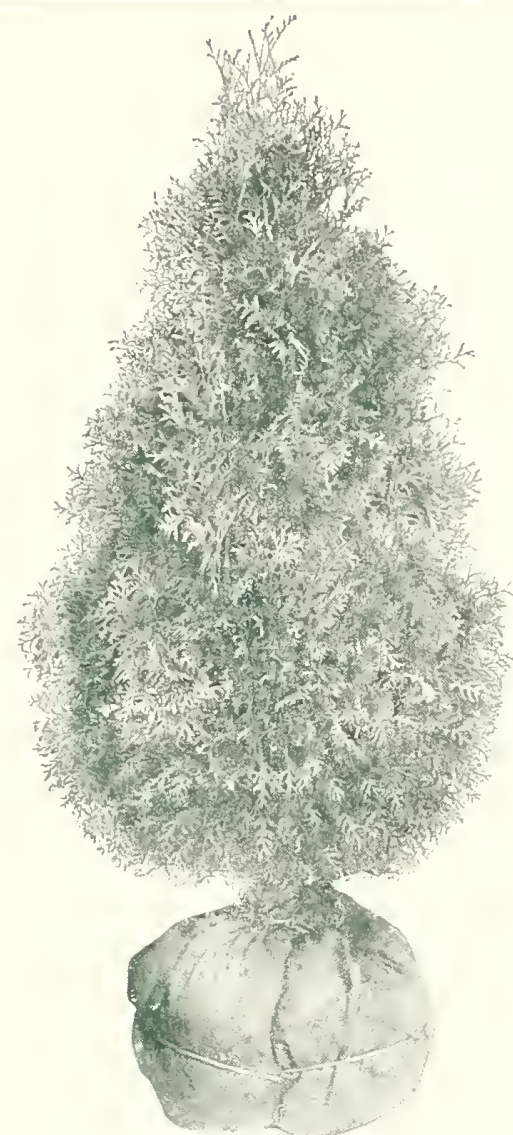

PYRAMID ARBOR VITAE

or vases as well as in formal work where symmetry is especially desired.

ARBOR VITAE, ORIENTAL or CHINESE, T. orientalis. This has the typical pressed foliage of the Arbor Vitae family, but is inclined to branch erect forming in "folds" about the stems of the plant. It is different from the other varieties in character of growth and appearance. It grows very rapidly and can be used where mass effect is wanted, as a specimen or in a hedge. It shears especially well and it is often necessary to prune it to make it real compact as it is inclined to grow open.

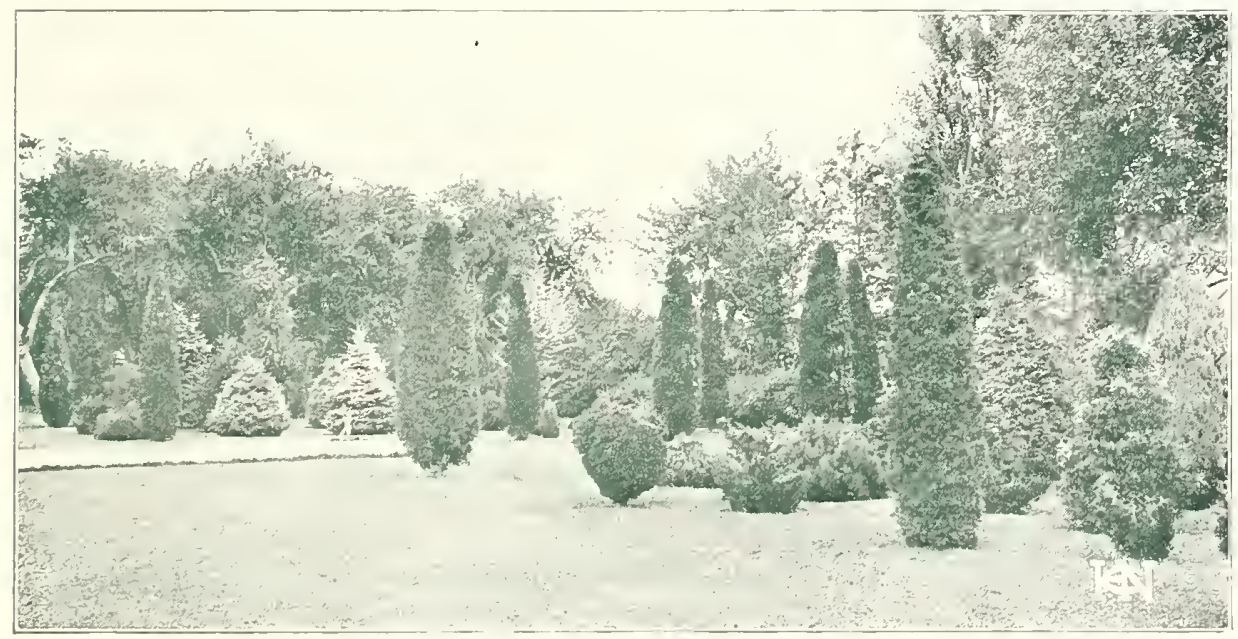

A GROLP OF SPECIMEN EVERGREENS

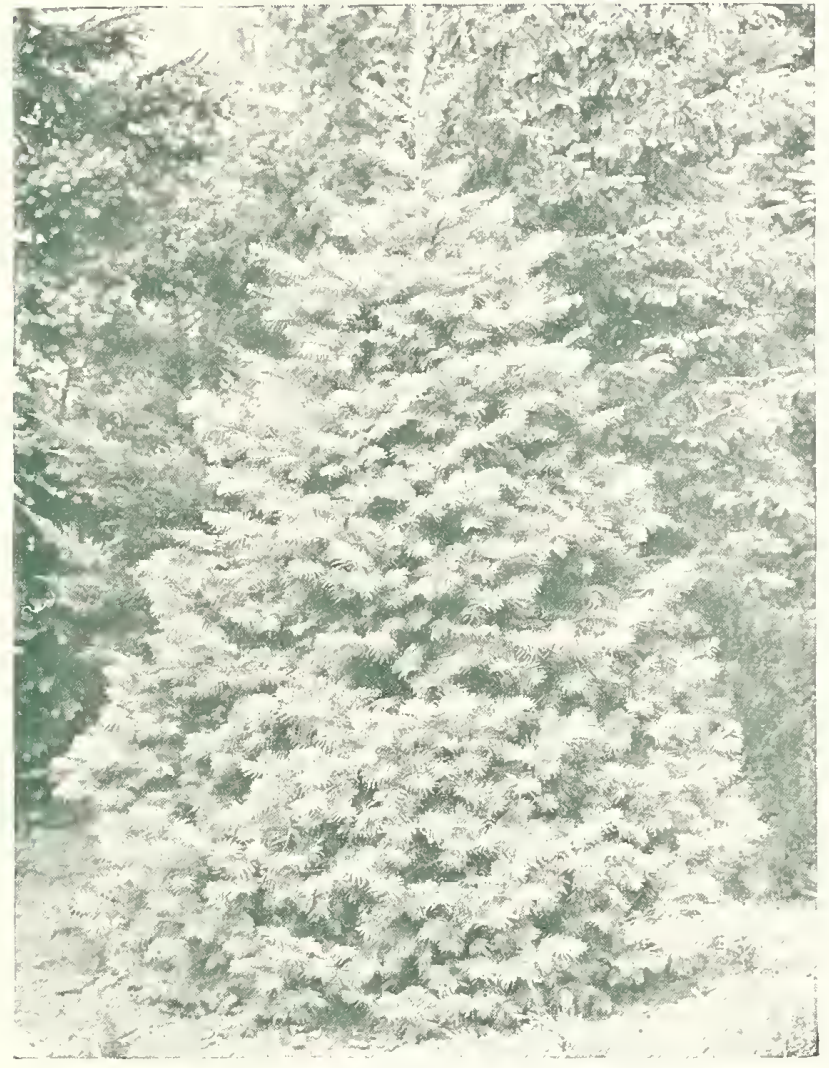

SPECIMEN FIR

ARBOR VITAE, PYRAMIDAL, T. occidentalis pyramidalis. This is strikingly attractive, being perfectly pyramidal in shape, spreading very little at its base and retaining the shape without shearing. The color is deep rich green and like all Arbor Vitaes is easy to transplant. For corners, 11 front of pillars, center or background of group plantings there is hardly an evergreen of the dwarf variety that is quite so popular.

ARBOR VITAE, SIBERIAN or WARE'S, T. occidentalis wareana. This is a small globe variety and its unusually dark green color makes it very useful. It is the darkest green of all the American Arbor Vitaes. It can be sheared to a perfect globe though if left to develop naturally it is oblong.

ARBOR VITAE, ELL. WANGER'S, T. occidentalis ellwangeriana. This has very fine cut foliage and does not exactly resemble the "pressed" leaves that characterize the other varieties. This is very compact growing and has a soft feathery appearance not found in other evergreens.

A R B O V I TAE, GOLDEN, T. occidentalis lutea. This 
has bright yellow foliage in the growing season and is especially fine where contrast in color is wanted. It is distinctly pyramidal in shape, being broad at the base.

\section{The Firs}

FRASERI. Fraser Fir. Dark green, hickest foliage, blue underneath; compact, pyramidal habit. One of our choicest evergreens. The only permanent "Balsam Fir." Thousands of perfect specimens up to sixteen feet. This is a specialty at Hedge Lawn Nursery and we can supply in car lots for mass planting or to the Nursery Trade. This fine species comes from the high Carolina Mountains. There are few evergreens we can recommend so highly.

ABIES BALSAMEA. Balsam Fir. The Firs are of soft texture and lovely sweeping lines. They provide great beatity in formal plantings, and also blend with naturalistic effects.

FIR, NORDMANN'S. Abies nordmanniana. A pyramidal tree with small dense needles dark green on surface with silvery tones on underside. It is a little slow to get started but when it has developed its tap root will make a fine specimen plant.

FIR, SILVER or WHITE. A. concolor. This tree has unusual light bluish-green foliage and rivals the Blue Spruce in attraction in the spring. It is pyramidal in shape and will grow quickly when it becomes established. One of the best evergreens for the lawn.

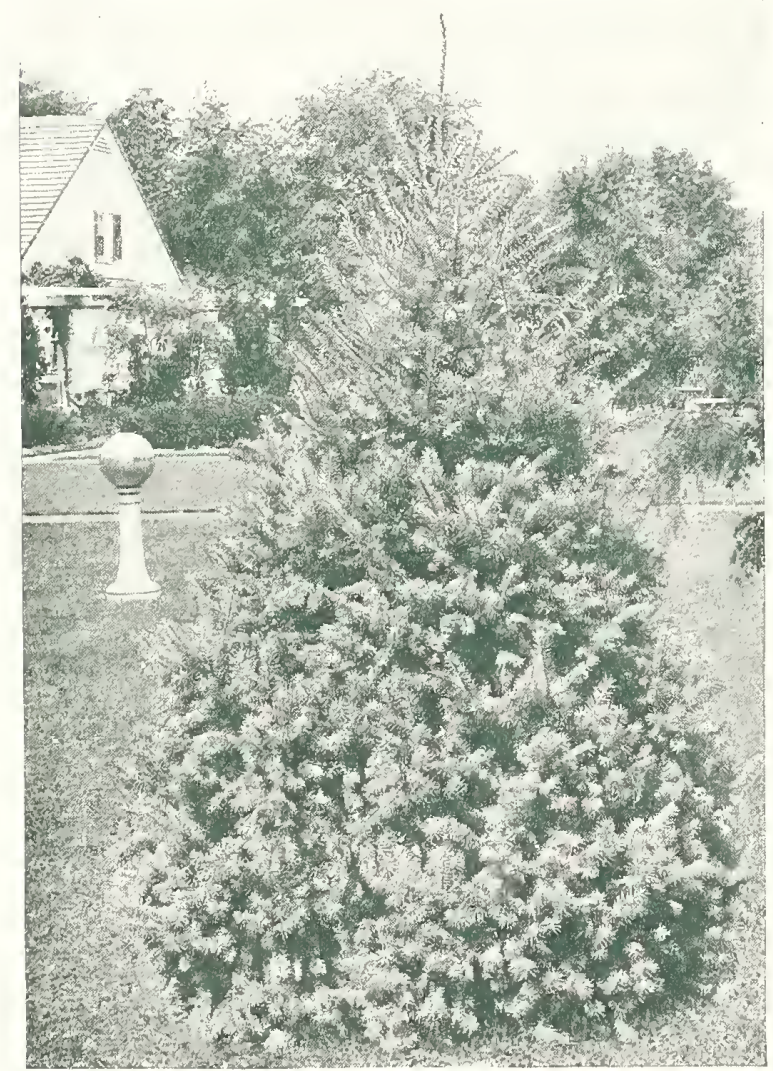

BALSAM FIR

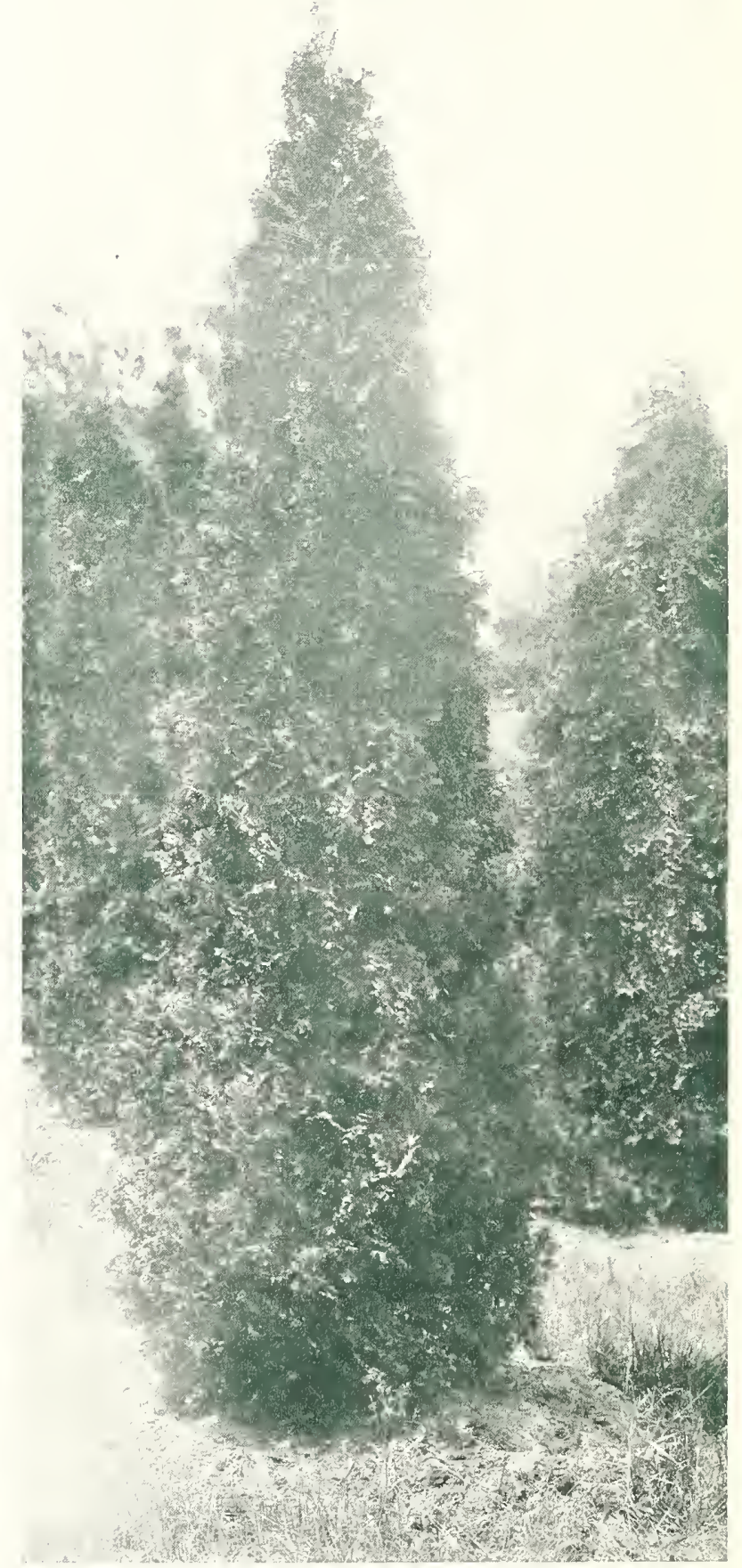

PYRAMID ARBOR VITAE

\section{Hemlock}

TSUGA CAROLINIANA, Carolina Hemlock. Carolina Hemlock is unique in habit, with dark, dense, tufted foliage on sweeping pendulous branches with a "Japanese effect." It is hardier and more adapted to trying city atmospheres than the Canada Hemlock and seems to thrive in southern latitudes where the latter becomes thin, yellow and 


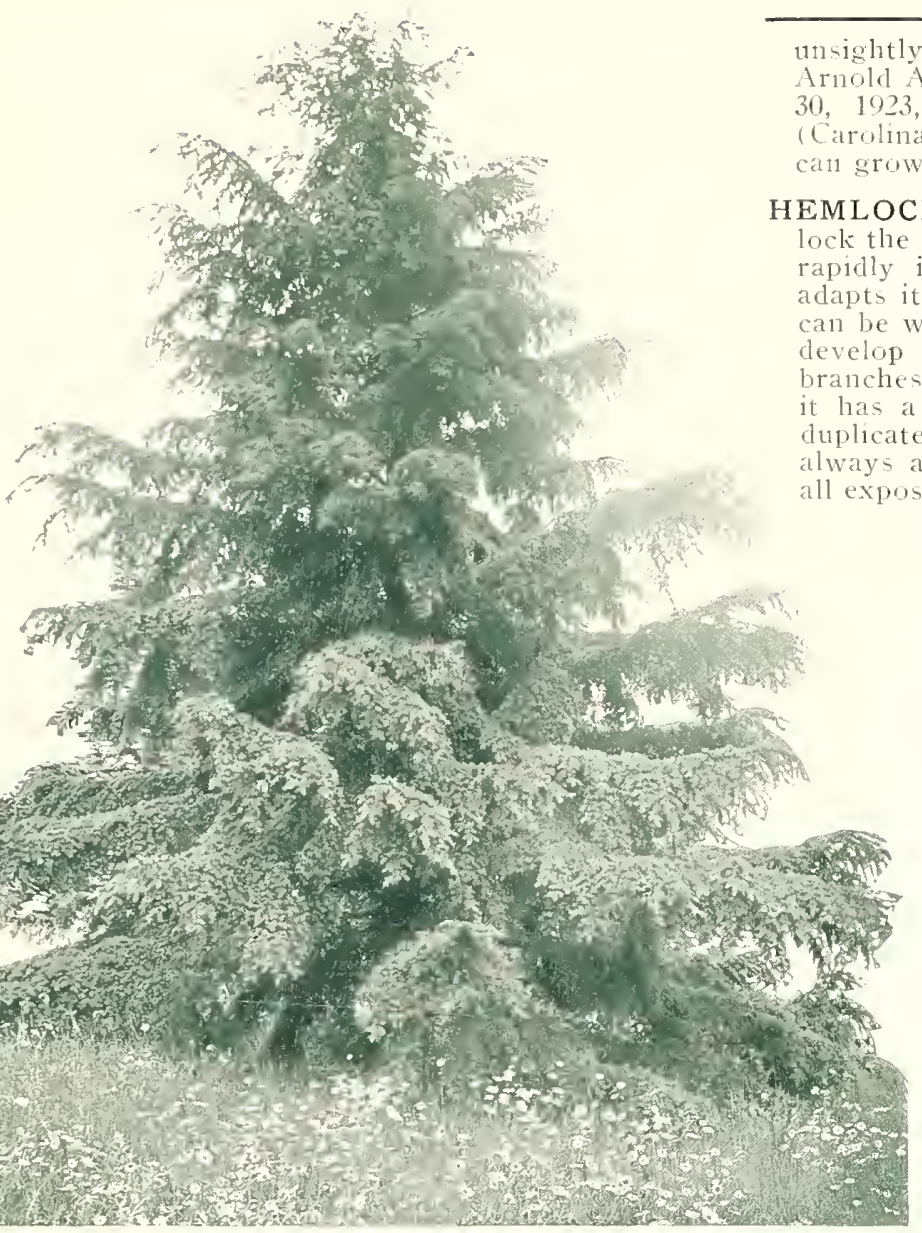

THE CAROLINA HEMLOCK 117sightly. Professor C. S. Sargent, Director of the Arnold Arboretum, says, in a letter dated ()ctober 1923, "As you know, I consider this tree memlock the handsoment conner we

EMLOCK, Tsuga canadensis. We consider Hemlock the very best of all the evergreens. It grows apilly in the open lawn, in confined places it itself to all conditions and if kept sheared develop naturally it has sweeping pendulous branches that are mont graceful and when sheared it has a soft billowy appearance that cannot be iiplicated with other evergreens. The foliage is always a very deep green and as it will grow in 1 exposures and under adverse circumstances it is more largely planted than any other evergreen. We have a saying here, "When in doubt, plant a Hemlock."

\section{PLAN EARLY}

Professional landscape architects -hould be engaged where the location of walks, drives or pergolas and the like is involved, or where extensive landscape improvements are contemplated. We are acquanted with many of the best landreape architects throughout the country to whom we will gladly refer you upon application.

One other suggestion and that is don't wait until you are ready to plant. Our business is all crowded into a few weeks of fall and spring and we must move our products hurriedly. We like to give these plans personal attention. If you wait until the last minute we won't be able to render our best service. Try to send in your plan early and we can make a lay-out for you with more thought.

606 Maiden Lane

ROANOKE, VA. Jan. 2, 1925

HedGe LAWN NuRserY, Roanoke, Virginia

Gextlemen :

Enclosed please find check covering evergreens received a few days ago, which are beautiful.

Perhaps you will be glad to know that the evergreens and shrubs which you sold me last spring are growing beautifully and have been greatly admired by many of my friends.

You are to be commended on selling such fine and liealthy specimens and Roanoke should be proud of having such a dependable nursery, which offers such a large and varied stock to select from.

Yours very truly,

C. L. Callahan.

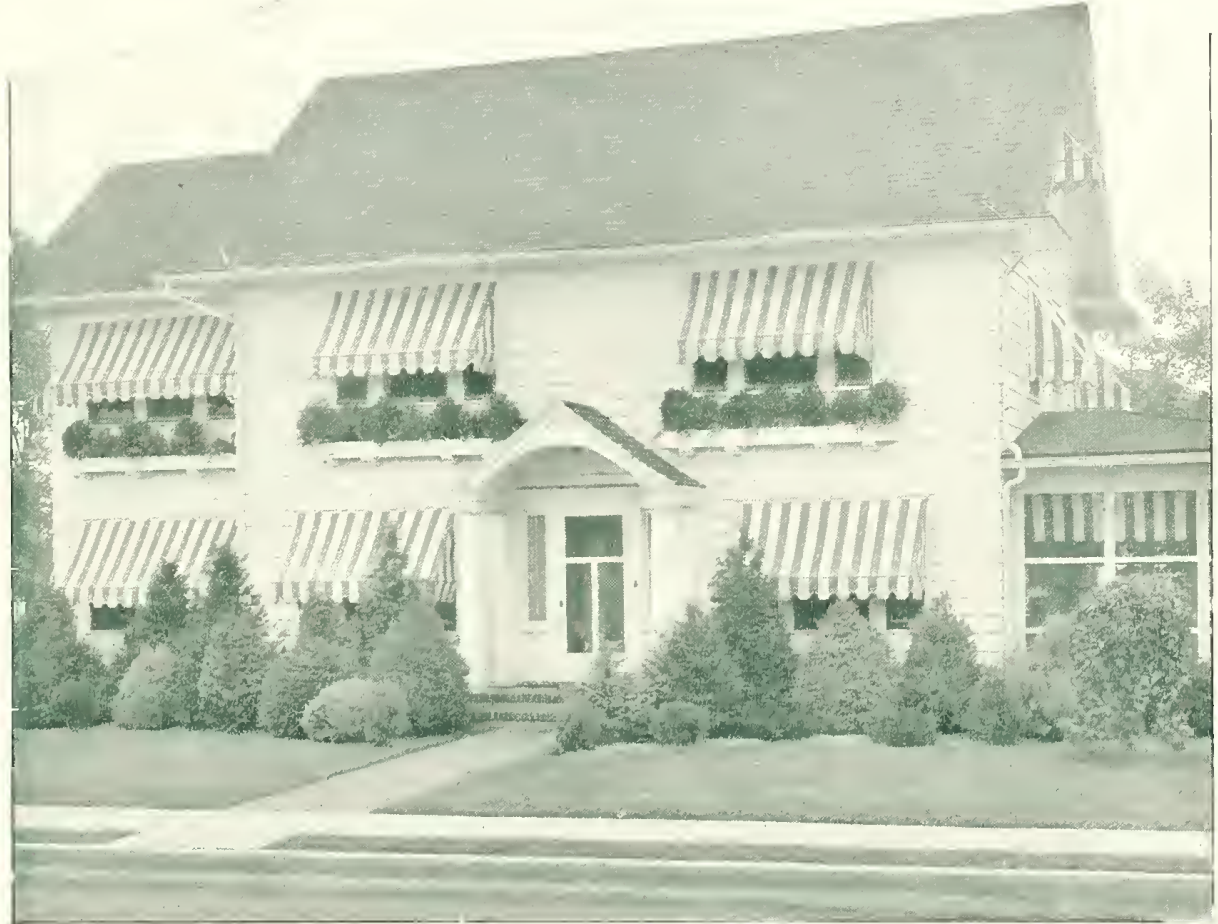

AN ATTRACTIVE, PLANTING 


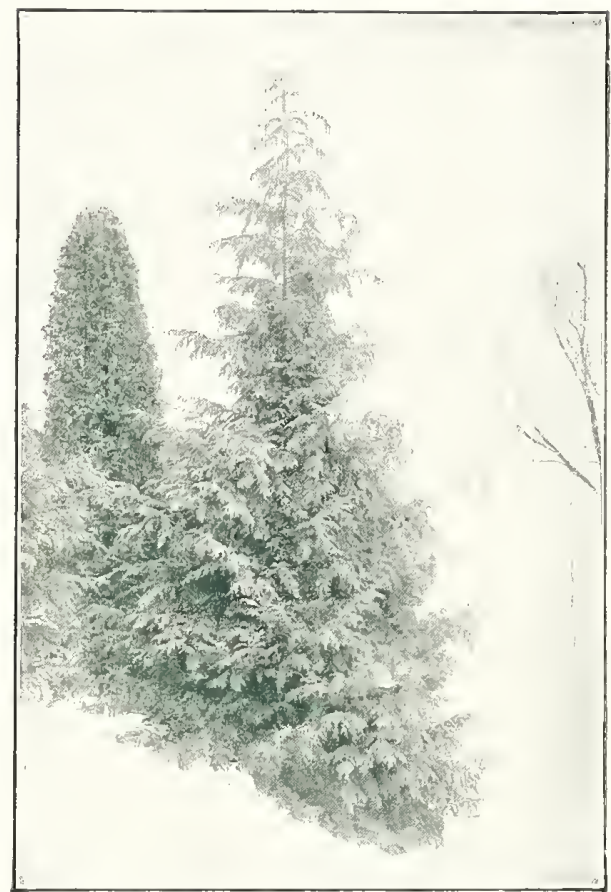

HEMLOCK

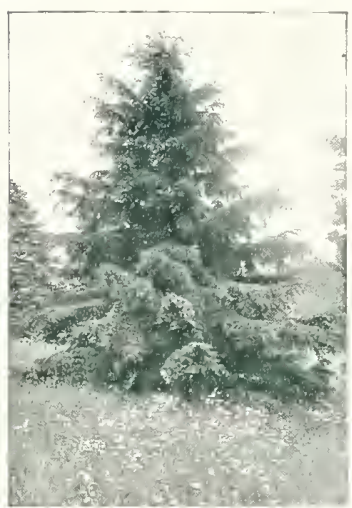

CANADIAN HEMLOCK

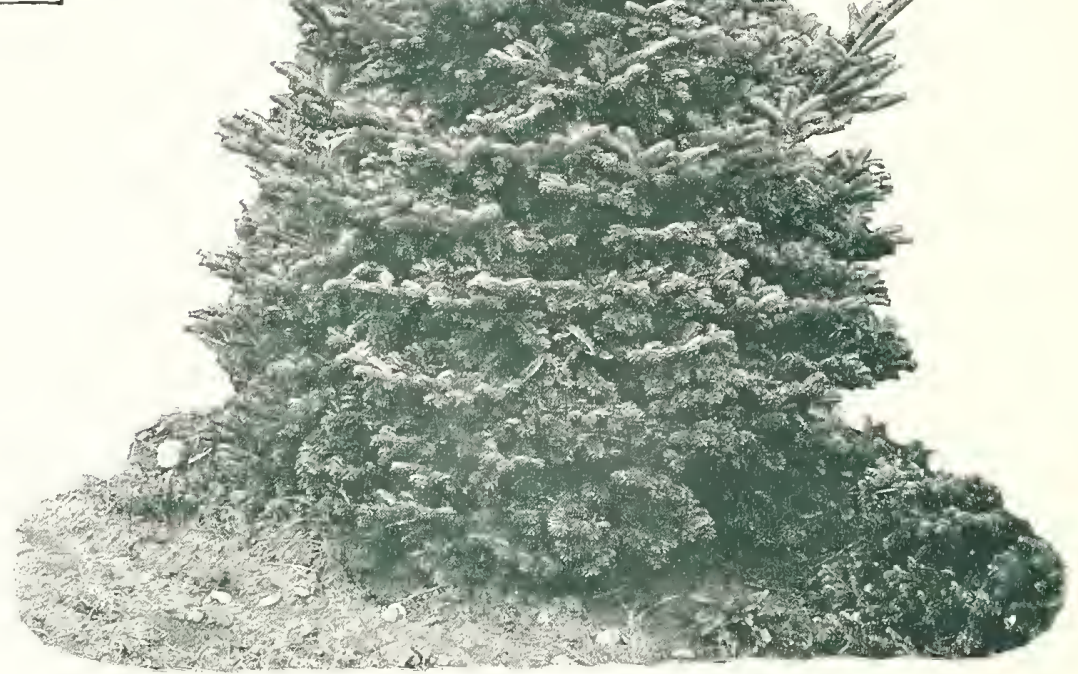

ONE OF OUR SPECIMEN FRASER FIR

\section{BUILDING MATERIAL}

Roanoke, Va., January 8, 1925

Hedge Lawn Nursery,

Roanoke, Virginia

Gentlemen :

This is to advise you that the shrubbery and evergreens purchased from you last fall are all living and doing nicely, and that your work in planting same has been entirely satisfactory.

If at any time I can be of service to you, do not hesitate to call upon me.

Assuring you of my appreciation of your good work, I am

Yours truly,
Respectfully,

W. C. Weaver, President. 


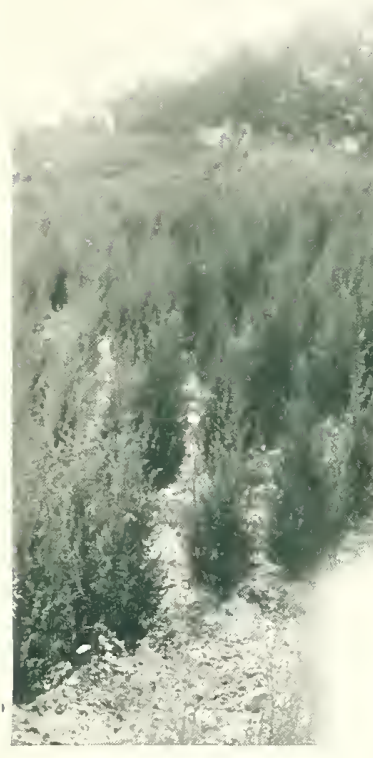

A BLOCK OF IRISH JUNIPER

\section{The Junipers}

JUNIPER, Blue. Juniperus virginiana glauca. This is one of the best trees offered to-day. It grows pyramidal but has graceful spreading branches if left untrimmed. When sheared, a perfect column may be had. In color a light blue and a distinct contrast from any other of this group.

JUNIPER, IRISH. J. communis hibernica. This is a decided columnar form and immediately attracts attention. The foliage is a glaucous green. For formal work, especially in contrast with other plants, it has decided advantage over anything you can use for such work. It is very slender in habit of growth and needs no shearing.

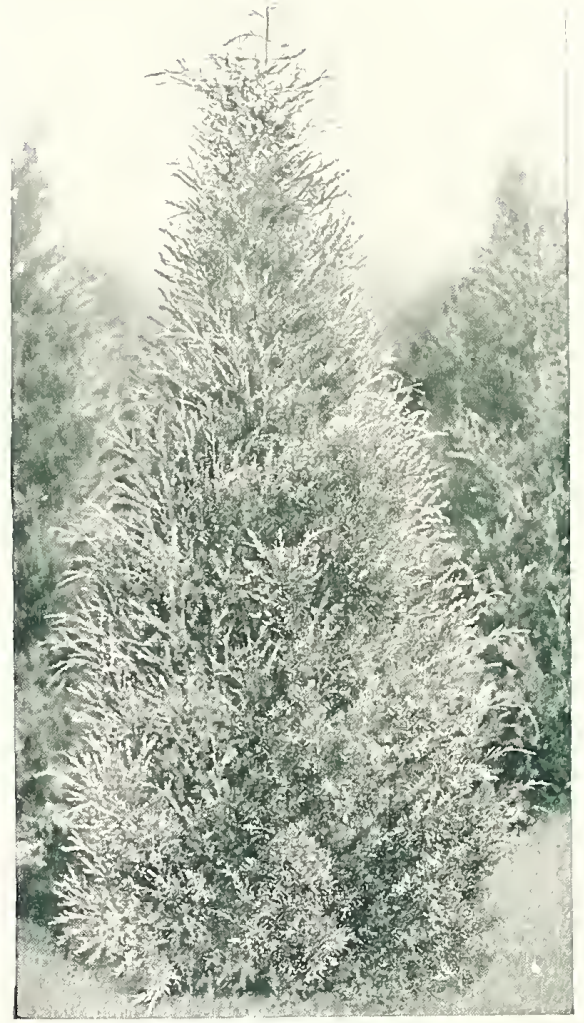

JUNIPER

JUNIPER, PFITZER'S. J. chinensis pfitzeriana. This is the most popular of all the spreading types. Its habit of growth, its pendulous branches and attractive foliage is strikingly beautiful. The branches are horizontally spreading and the terminals slightly drooping. It lays close to the ground and for edging larger plantings there is

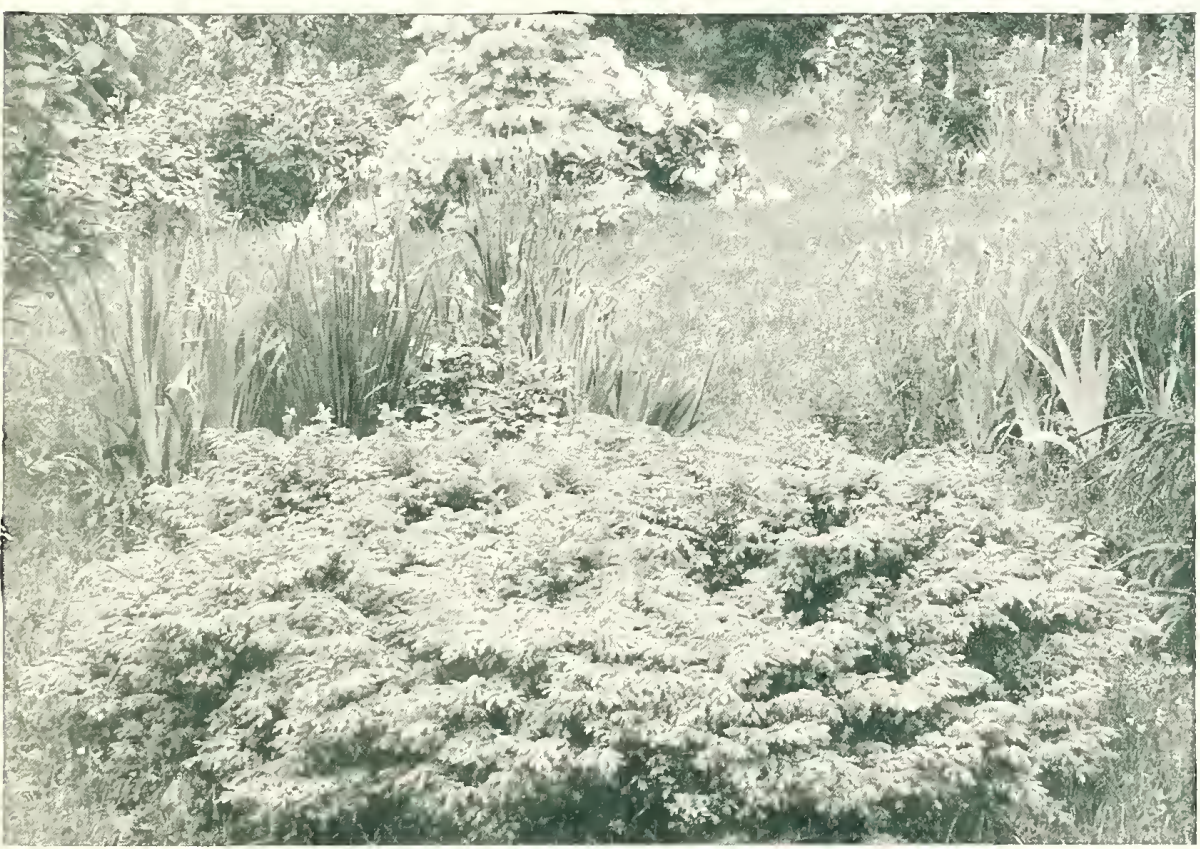

DWARF SPREADING JUNIPER nothing superior. Flowing lines are especially valuable in landscape planting and this Juniper seems to fill this requirement better than any other. The foliage is a gray-green both summer and winter and because of its ability to withstand the soot and dust of cities will thrive where others fail. Another advantage is that it lends itself to severe pluning in case it outgrows its location.

JUNIPER, MONUMENTALE. A beautiful cone-shaped variety with dark gray foliage. Very formal.

JUNIPER, SAVIN'S. J. sabina. One of the best. Spreading fan shape habit, of pleas- 
ing color of dark green. Stands the city dust, soot, etc, exceptionally well

JUNIPER, SWEDISH.

J. communis suecica. This is another colnmmar form of gray. green foliage and nnunually attractive in the winter. Where formal effects are wanted thin can be used It is not as quick in growth as Irish Juniper and in limited areas is preferred.

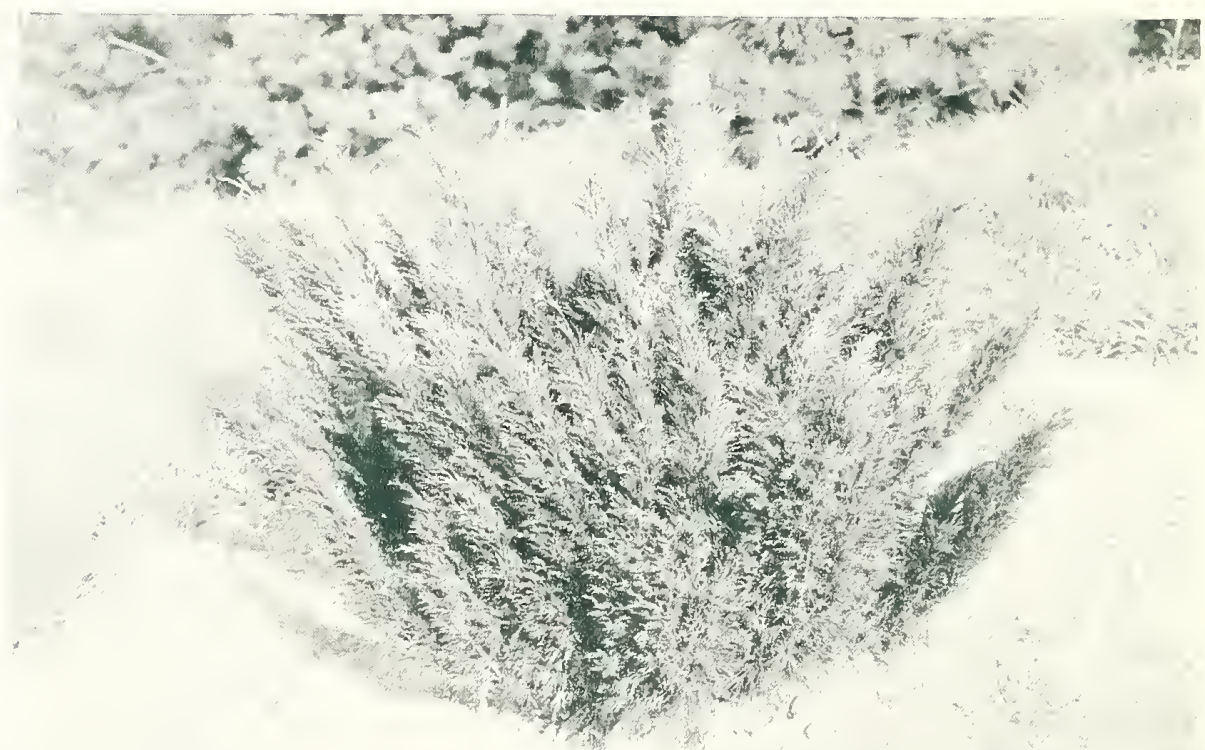

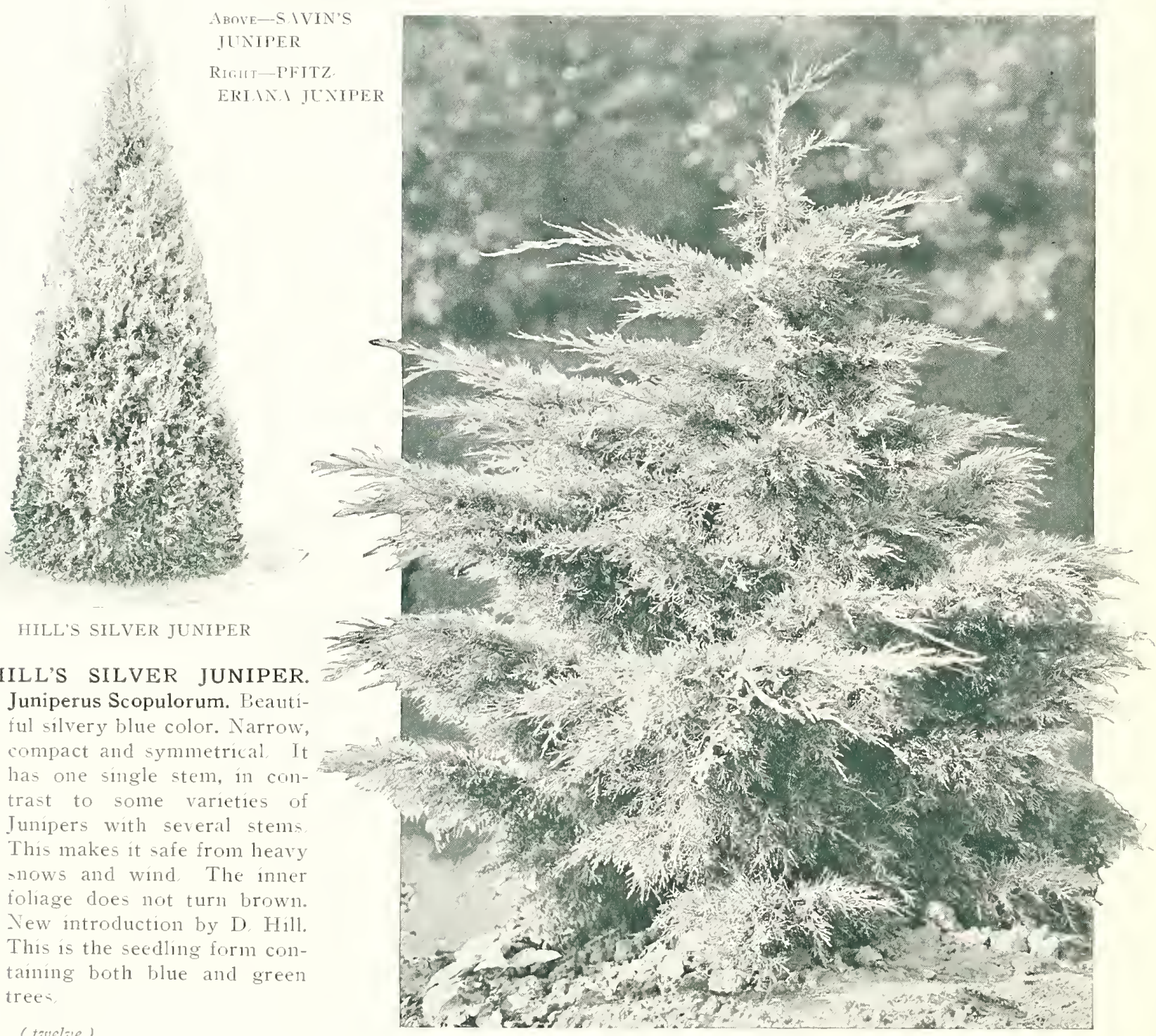




\section{Yews}

YEW. Taxus. This is a group of evergreens that is just coming into use in landscape work. In the end it is rather doubtful if they will succeed in most localities out in the open, but along north foundation walls, in semi-shaded positions their value is not appreciated. The foliage is as bright and pleasing as Boxwood, the needles like those of the Spruce or Fir, but larger. Plants may be clipped to formal shape or left to develop naturally. They are perfectly hardy in climates much colder than ours and, we believe, would do well used in shady spots where other plants fail.

CUSPIDATA. Capitata. Of all the Yews this is the only hardy, upright-growing variety in the northern states. A fast grower, standing our most severe winters and keeping its fresh color throughont the year.

CANADENSIS. Canadian Yew. Low-spreading and bushy, with small, pale green leaves, which are less numerous than the English Yew and turn to a pretty reddish tint in winter. Fruit is bright red. Very nice habit; very hardy.

TAXUS BACCATA REPANDENS. This is the hardiest of all prostrate varieties and will grow in almost any position. It is excellent for hedging, grouping and covering banks. The slender, pointed leares gently curve upward and are of a lustrous green.

NANA. Brevifolia. Really an excellent Yew, with fine, spreading branches and rich deep green, short leaves. Highly recommended.

JUNIPERUS CHINENSIS JAPONICA AUREOVARIEGATA. Japonica aureo-variegata. Foliage green, sprayed with yellow shoots.

FASTIGIATA. Hibernica. Irish Yew. Pyramidal, upright growth; slow grower; very attractive and formal: the stout branches are closely crowded to the center and the glossy green leaves are spirally arranged around the erect branchlets.

TAXUS BACCATA. English Yew. Bushy; dark, glossy foliage, rather leathery and about threequarters of an inch in length. The berry-like fruit is intense scarlet and stands erect. Tree attains great age.

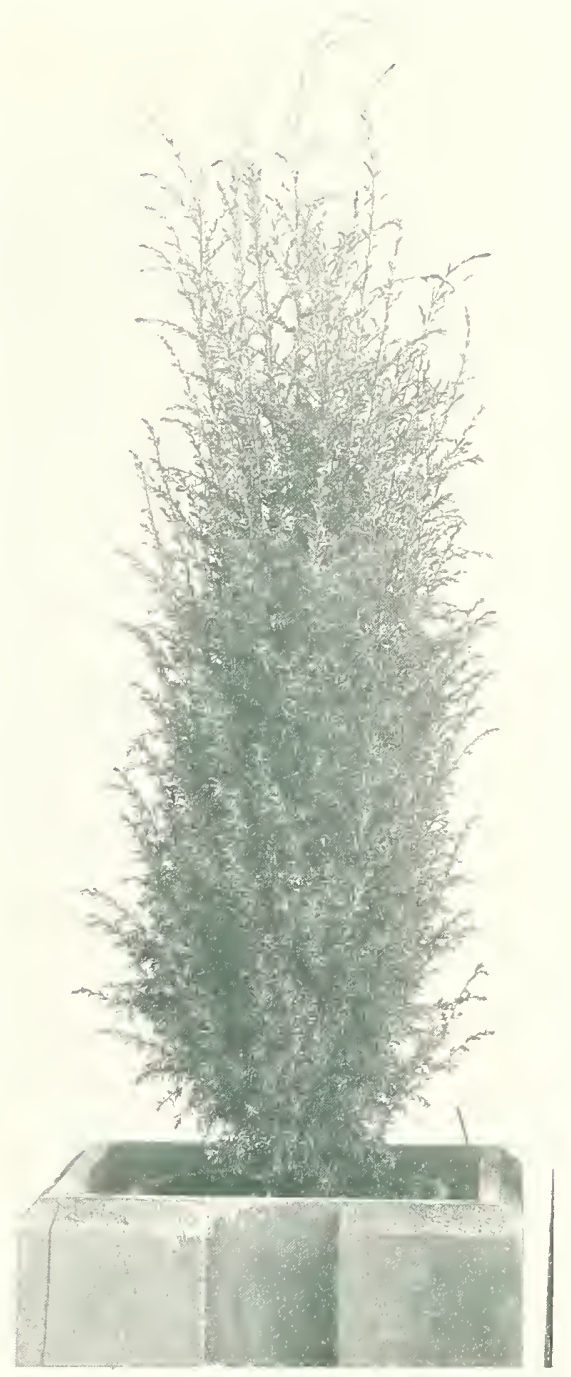

IRISH TLNIPER

\section{The Pines}

PINE, MUGHO. Pinus montana mughus. This is an excellent dwarf Pine, being globe shaped and erect branching. It is very attractive especially in spring when the new growth, which seems like miniature candles, completely covers the bush.

S T R O B U S. White I'ine. One of the bent native Pines. The branches are horizontal and in regular whorls, with smooth bark. The long. slender leaves occur in groups of five and gently droop orer. proclucing a pleasing. 
pale green effect. The cones are generally over six inches long, and add a wonderfully picturesque touch to the tree.

RESINOSA. Norway or Red Pine. Very ormamental; is quite hardy and of vigorous growth; the needles are lustrous green, long and most often in pairs, contrasted by the russet-colored stubby cones.

\section{NIGRA AUSTRIACA}

Austrian Pine. A robust, stately tree of rapid growth, and very hardy. Stiff, long, dark green leaves in pairs. The winter buds are whitish and long.

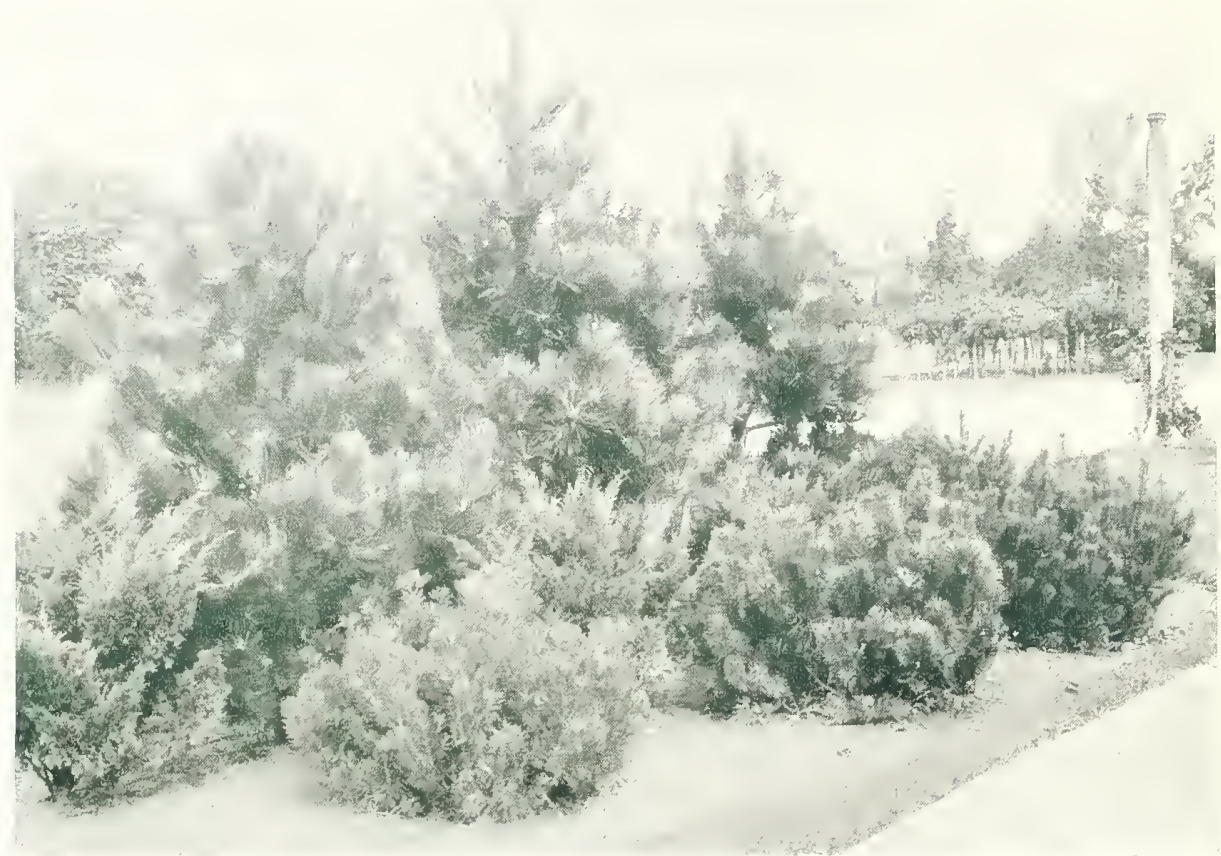

A GROUP OF AUSTRIAN AND MUGHO PINE

\section{The Spruces}

PICEA, pungens. Colorado Spruce. Sharp leaves are bluish to dull green and rather thicker than usual. Branches horizontal, in regular whorls.

PICEA, glauca. Colorado Blue Spruce. Grafted from selected specimens only. A bluer form of

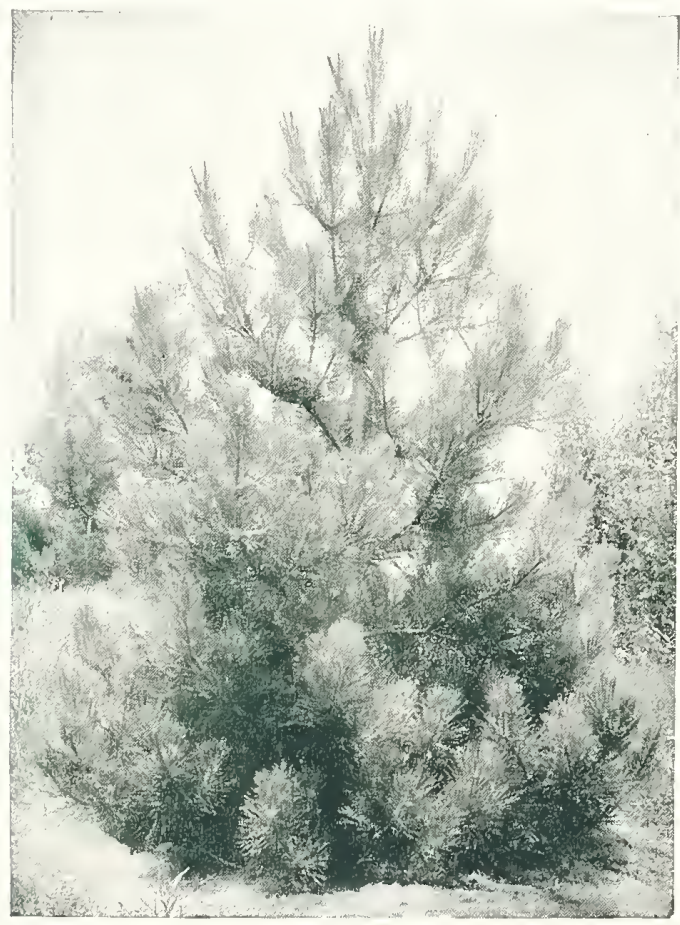

AUSTRIAN PINE the preceding, and in many ways just as effective as the Koster variety following.

SPRUCE, KOSTER'S BLUE. Picea pungens kosteri. Its striking blue color is noticeable as far as it can be seen. It is best used as a specimen with a dark background or in groups where contrast is to be had. The past few years it has become very scarce and the plants are decidedly expensive.

SPRUCE. Norway P. excelsa. This has been the mont popular of the Spruce family as it is easy to

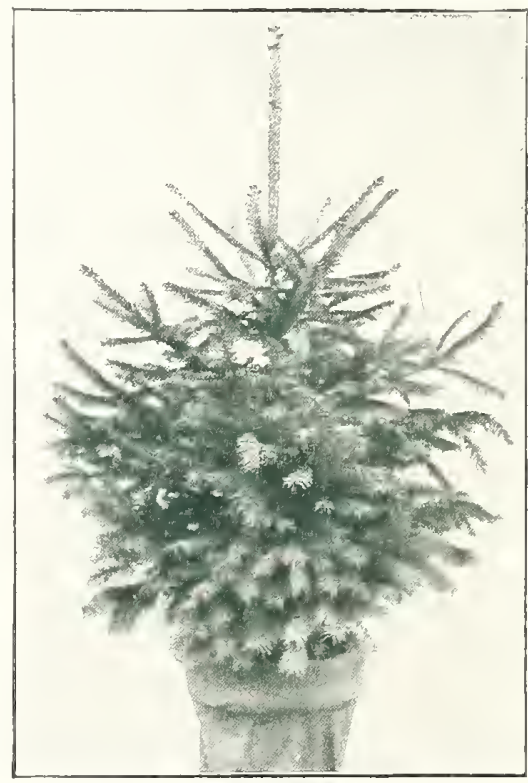

NORWAY SPRUCE-P. EXCELSA 


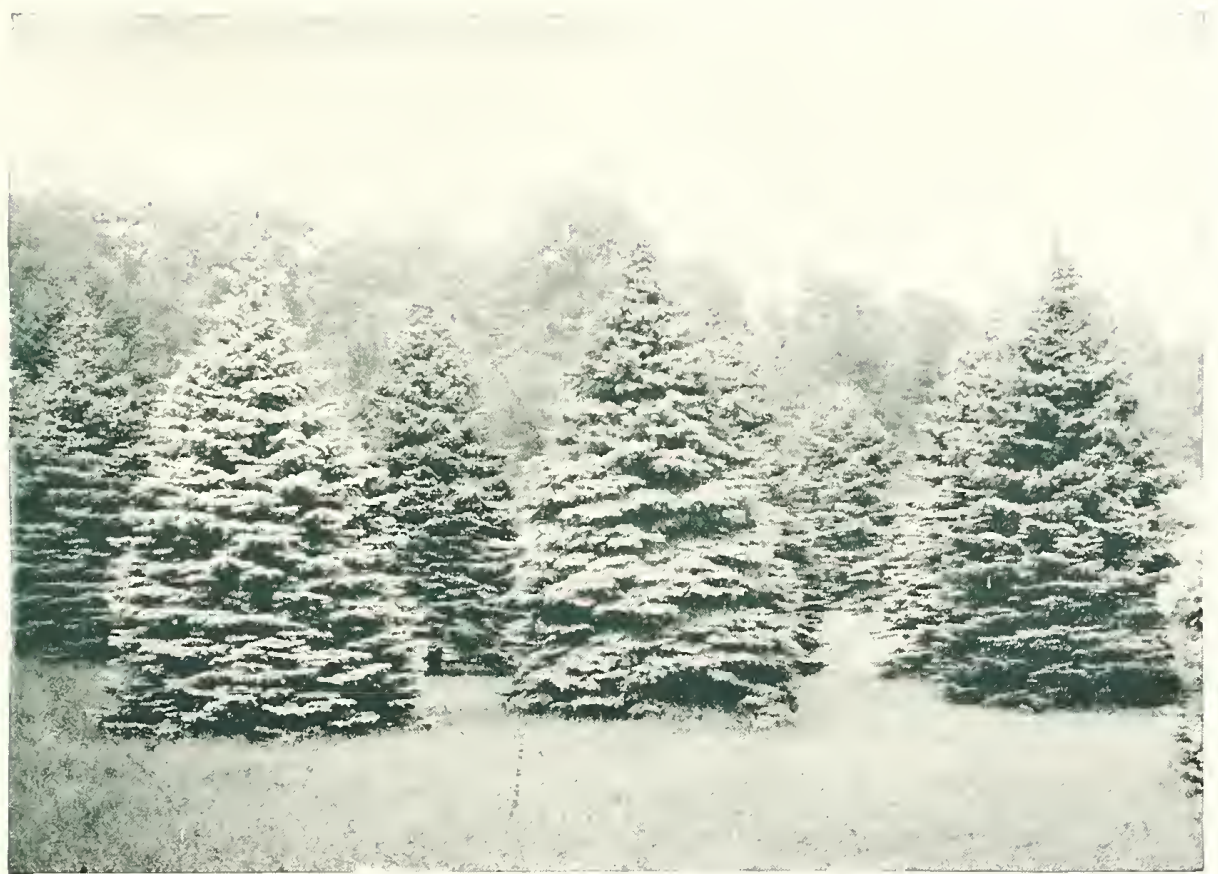

SPECIMEN COLORADO BLUE SPRUCE

transplant, hardy and grows rapidly. Pyramidal in shape and when used as a specimen is very fine. For screen, wind break and hedges they are equally appropriate. The needles are dark green in color. Norway Spruce has been largely planted and really has no serious fault.

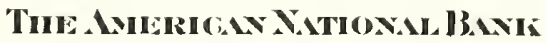

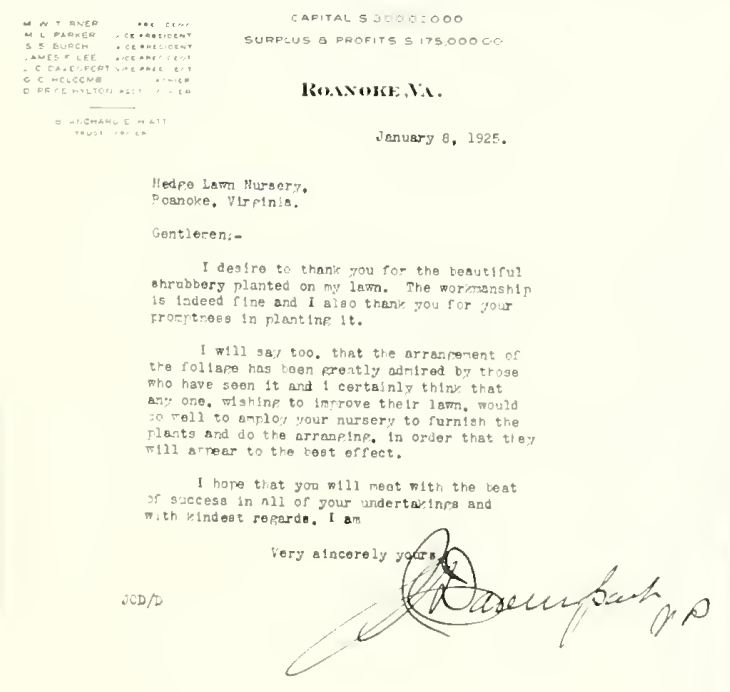

SPRUCE, WHITE. Picea canadensis. This is a very hardy evergreen with light green foliage and similar in many respects to the preceding variety except that it is decidedly slower growing in our locality and can safely be used where a medium sized or small tree is wanted.

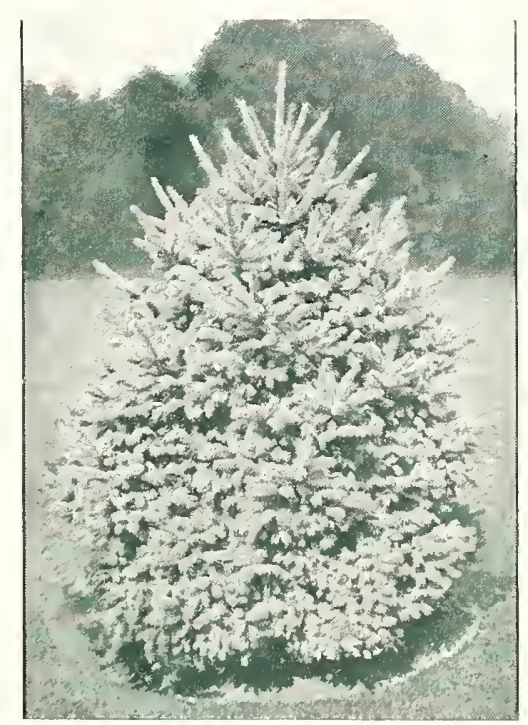

BLACK HILL SPRTCE 


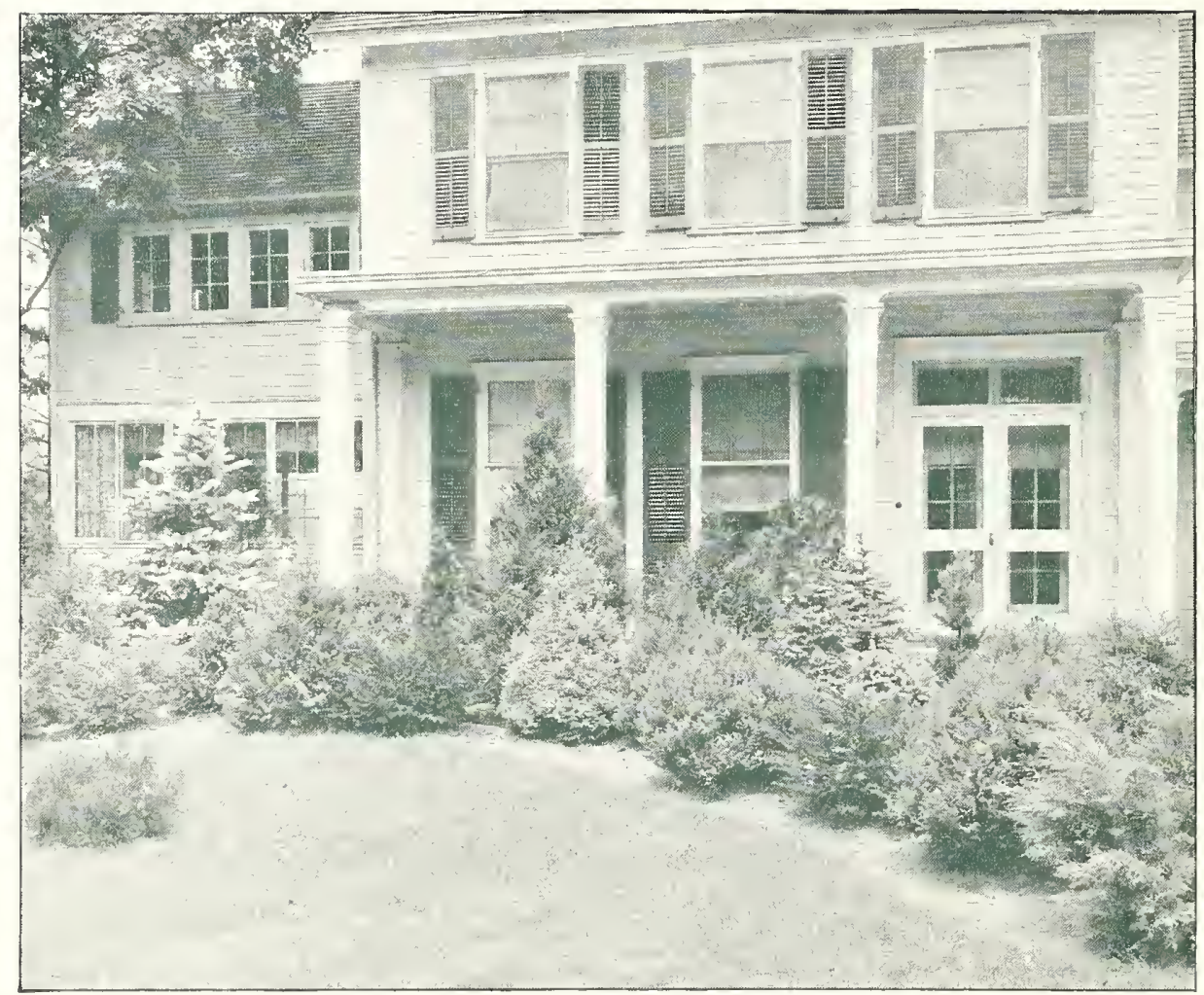

AN ATTRACTIVE PL.NNTING. BeLow-A FIELD OF SMALL EVERGREENS

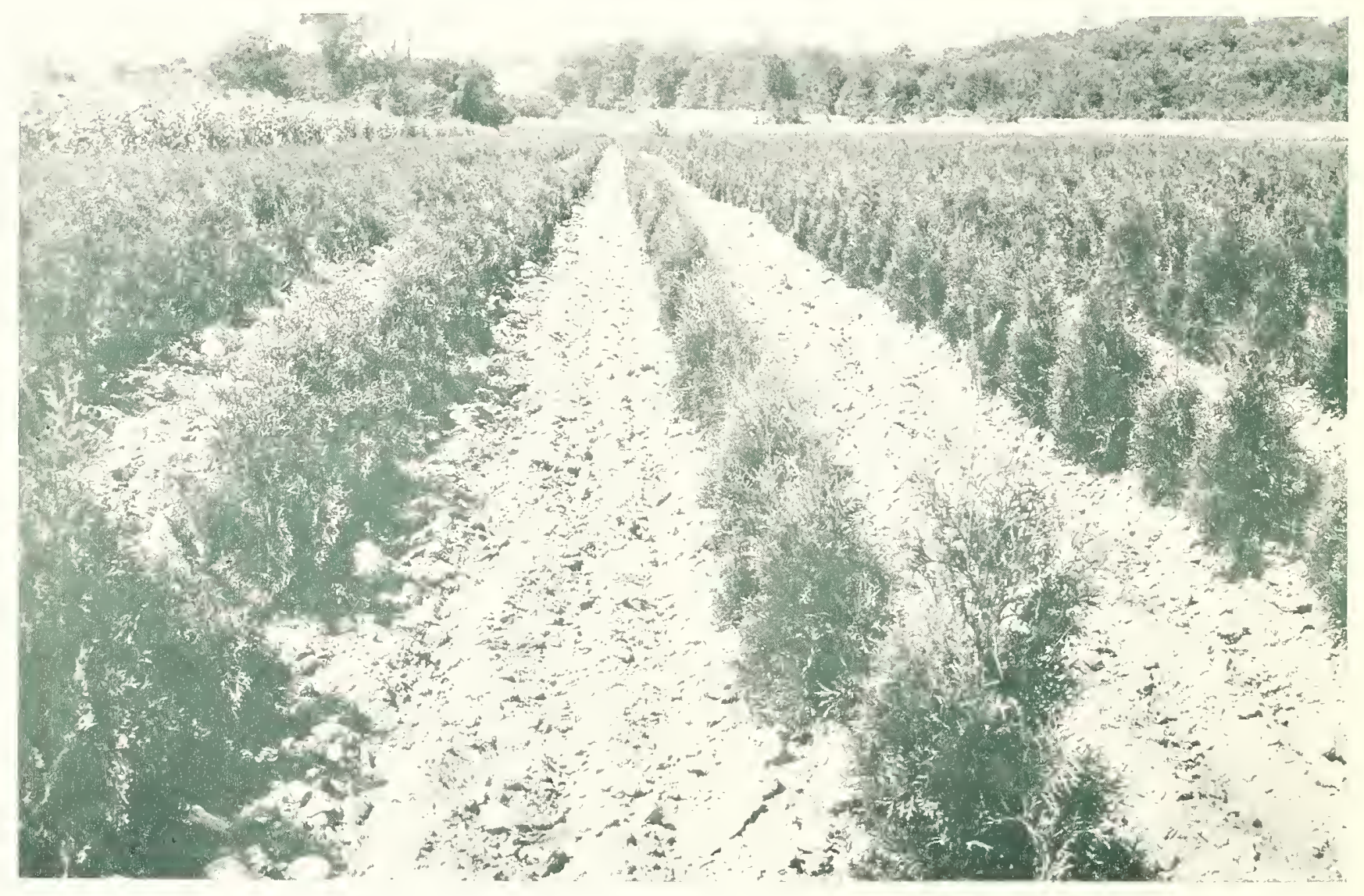




\section{The Retinospora or Japan Cypress}

FLAVESCENS. Sulphurea. Round head, bushy, covered with numerous small leaves of a suphuryellow tint. Very dense growth, but has a soft woolly appearance.

ARGENTEA. Silver-tipped foliage gives a lighter impression even than the type.

AUREA. Golden foliage. The most popular of all ornamental evergreen.

SULPHUREA. This is a mont beattiful variety; sulphur-tinted shoots; of compact growth; quite distinct.

SQUARROSA. Veitchii. Light bluish-green foliage, which is spreading and prickly; very dense growth.

RETINOSPORA, Pea fruited, or sawara Cypress. Chamaecyparis pisifera. The foliage of this resembles the Arbor Vitae very much and the tree develops decidedly erect with very graceful branches. When sheared especially does the foliage develop its true color. It is very lacy in appearance with a silvery color on the underneath side. It is a fine plant in the foundation where a heavy plant is wanted and on the lawn it makes an attractive specimen.

RETINOSPORA, Golden pea fruited. C. pisifera aurea. This has all the characteristics of the green form described above except that the foliage is a very light green or bordering on yellow. Both of these will do well in city planting where some tenderer evergreens fail.

RETINOSPORA, Plumed or plumed Cypress. C. pisifera plumosa. The foliage of this is a grayish green, very fine cut, and has a feathery appearance. It resembles a fine cut fern frond at certain stages of its development. Pyramidal in habit of growth and if kept sheared as all varieties of this family should be, in foundation planting it will make a wonderful specimen.

\section{RETINOSPORA, Golden} plumed. C. pisifera plumosa aurea. In habit of growth and appearance is like the green form precedingly described. The young foliage is very light green bordering on yellow and for contrast planting for foundation or lawn groups is one of the most popular.

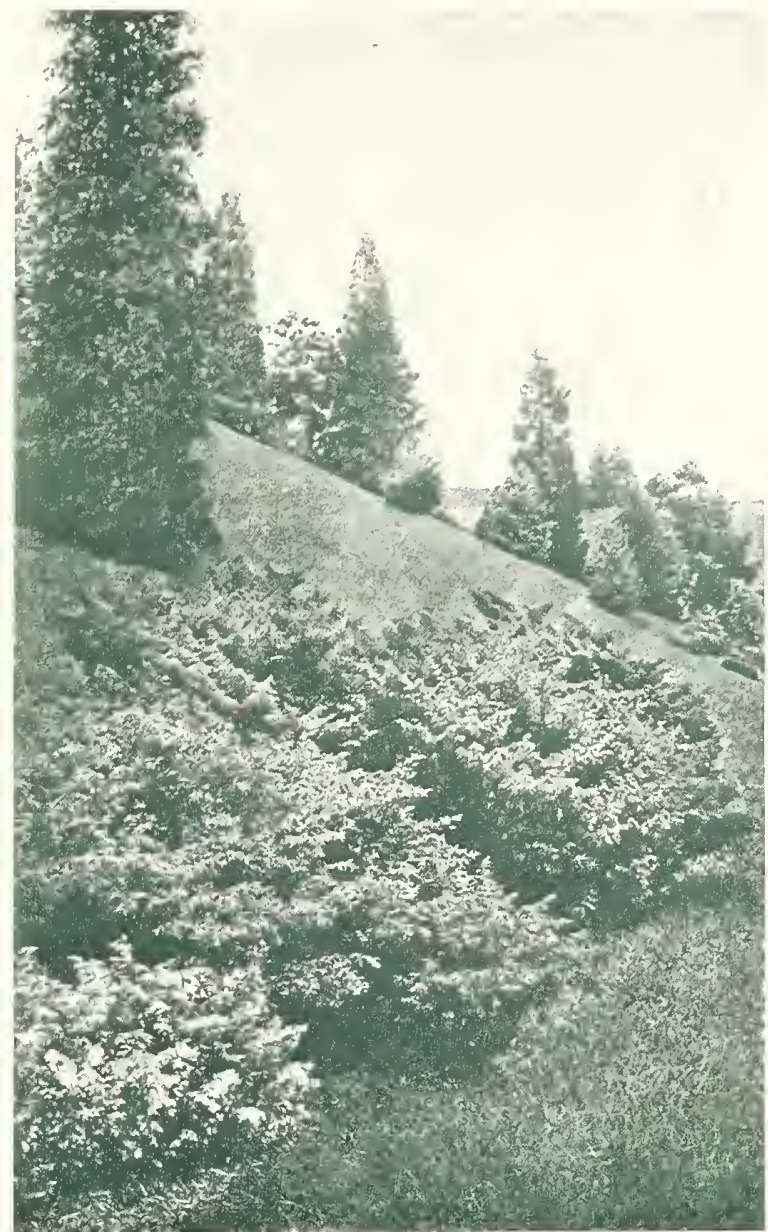

JUNIPERTS C.INADENSIS TS PERFECTLY AT HOME ON HILLSIDES OR ON PLAINS, AS A STNGLE SPECIMEN OR IN GROUPS. TIE BROAD, SPREADING HABIT GIVES IT I DISTINCT CHARACTER AMONG EVER(IREENS.

RETINOSPORA, Moss or blue. C. pisifera squar. rosa. The foliage of this is very fine cut and of all the evergreens is most lacy in appearance. Its unusual habit of branching gives it an attraction not found in any other of the evergreens. In color the foliage is a very pleasing blue. The plant hears well and usually is seen in a very compact form. If left to grow naturally it is unusually attractive. Should not be planted in sooty or dusty locations.

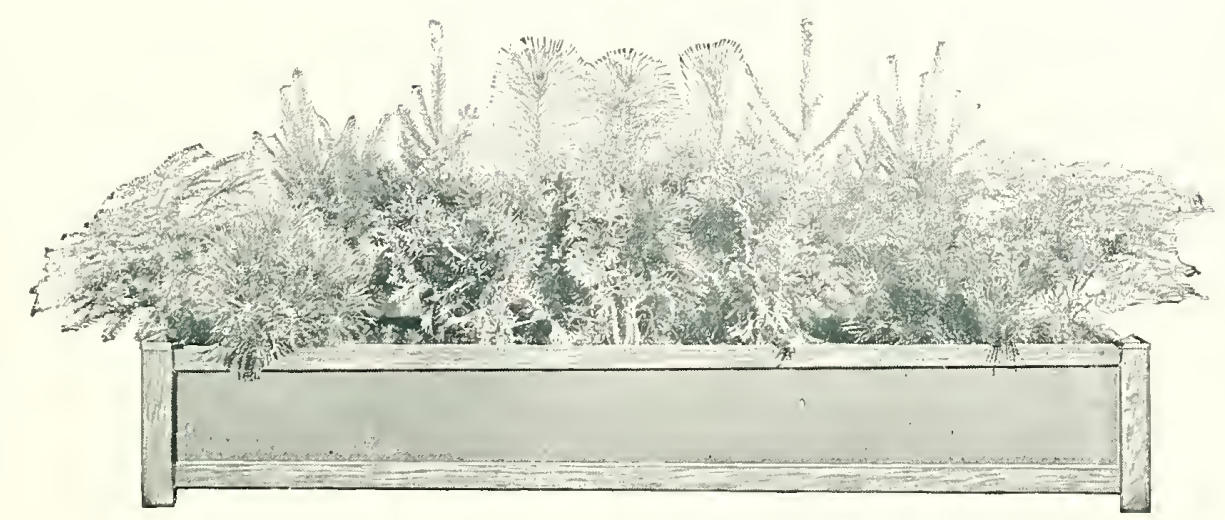

WE SPECIALIZE ON SAILI, EVERGREENS FOR WINDOW BOXES 


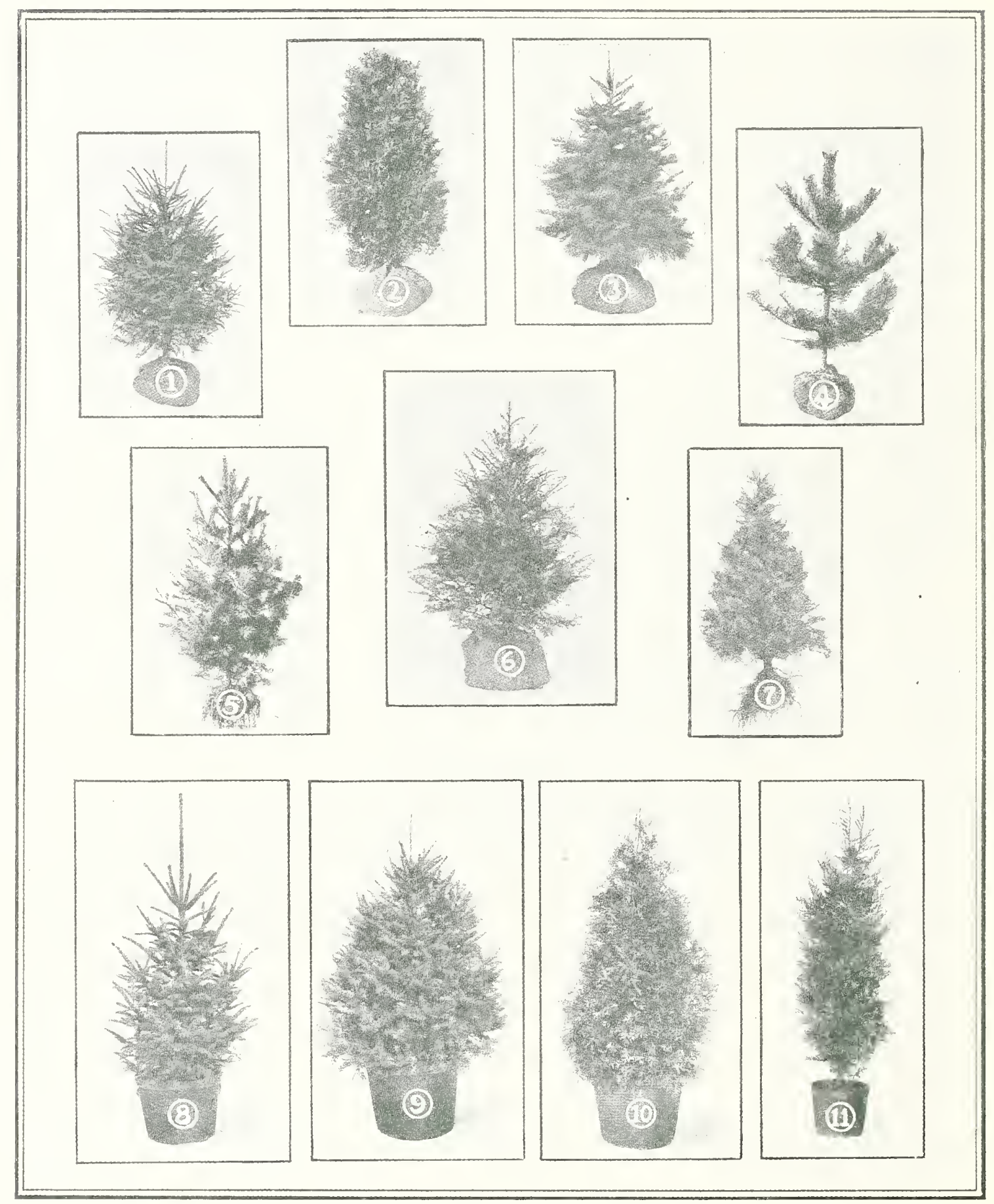

1. WHITE SPRLCE.

2. PYRAMID ARBOR VITAE.

3. CONCOLOR FIR.

4. WHITE PINE.
5. BALSAM FIR.

6. CANADIAN IJEMLOCK

7. COLORADO BLUE SPRUCE.

8. NORWAY SPRUCE.
9 BLACK HILL SPRUCE.

10. AMERICAN ARBOR VITAE.

11. TRISH TUNTPER. 


\section{BROAD-LEAVED EVERGREENS}

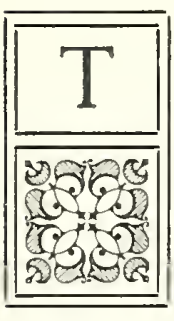

HE WINTER aspect of home grounds may be greatly enhanced by a planting here and there of some of the luxuriant shrubs listed in this department. Properly grouped in beds and borders or as foundation plantings, their rich, lustrous green foliage adds color and charm to the whole planting scheme. The flowers and berries that appear in their respective seasons make these shrubs stand out strongly as year-round ornamentals. A cool, moist soil, with a porous substratum, and a northern exposure, is preferred location with most members of the group. We ship all these Evergreen Shrubs with a ball of earth, wrapped in burlap. They will bloom the first season.

\section{The Evergreen Azaleas}

A family of Dwarf Evergreen Shrubs unique in the abundance and brilliancy of their blossoms, which occur in May. They are useful in border plantings in front of Rhododendrons and in groups and masses by themselves.

AZALEA AMOENA. Dwarf and bushy, with small green leaves, a coppery hue in winter. Always attractive, but doubly so in April or May, when clothed in a mass of dark pink or magenta flowers.

Easy to transplant and maintain.

AZALEA HINODE-GIRI. Vivid red flowers in spring make this plant extremely showy and desirable. Its deep green leaves turn reddish in the fall. An appealing plant to the garden lover and one deserving a place on any lawn.

ABELIA grandiflora. A. rupestris. A hardy shrub of great beauty. Evergreen South and nearly so North. G1 ows to a height of 4-6 feet.

COTONEASTER horizontalis. Prostrate Cotoneaster. A dwarf shrub with horizontal branches and small, dark green leaves Flowers pinkish: conspicuous bright red fruit. Fine as a border plant.

EUONYMUS japonicus. Evergreen Euonymus. Handsome, large shrubs, with glossy green leaves, holding their color all winter. Very hardy. Red berries.

BUXUS sempervirens arborescens. Tree Box. Succeeds in most well-drained soils, requiring protection, however, against extremes of both heat and cold. Some shade is nearly always desirable. Leaves small, glossy, bright green. Grows in dense, roundish form; valuable for formal planting. 10-20 feet. ANY SIZE AND SHAPE DESIRED.
BUXUS sempervirens suffruticosa. Dwarf Box. Similar to the above, but more dwarf. Valuable for low hedges and edging. 2-4 feet.

ILEX Aquifolium. English Holly. Leaves of intense deep, shining green, with undulating, spine-tipped margins. Berries bright scarlet. Conspicuous plant for winter effect, the glossy green foliage making a strong contrast with the scarlet berries. An excellent tree for the South and may be grown in the North if protected in winter. Height 25-30 feet.

ILEX crenata. Japanese Holly. A shrub with small, glossy, dark green leaves and black berries. At a distance resembles boxwood. Perfectly hardy in the South and makes a good hedge plant. 6-12 feet.

MAGNOLIA grandiflora. Common evergreen Magnolia of the South, with large, handsome white blooms which, combined with its large, glossy green leaves, remaining on throughout the whole year, make this the greatest of all the southern ornamental trees. 30-40 feet. June 5 th to July 10 th.

MAHONIA Aquifolium. Holly-leaved Ashberry. A handsome, ornamental shrub, with dark, lustrous green, spiny-toothed leaves. In winter the foliage assumes a bronzy or coppery hue. Produces many yellow flowers in early spring. Berries blue or nearly black. 3-6 feet.

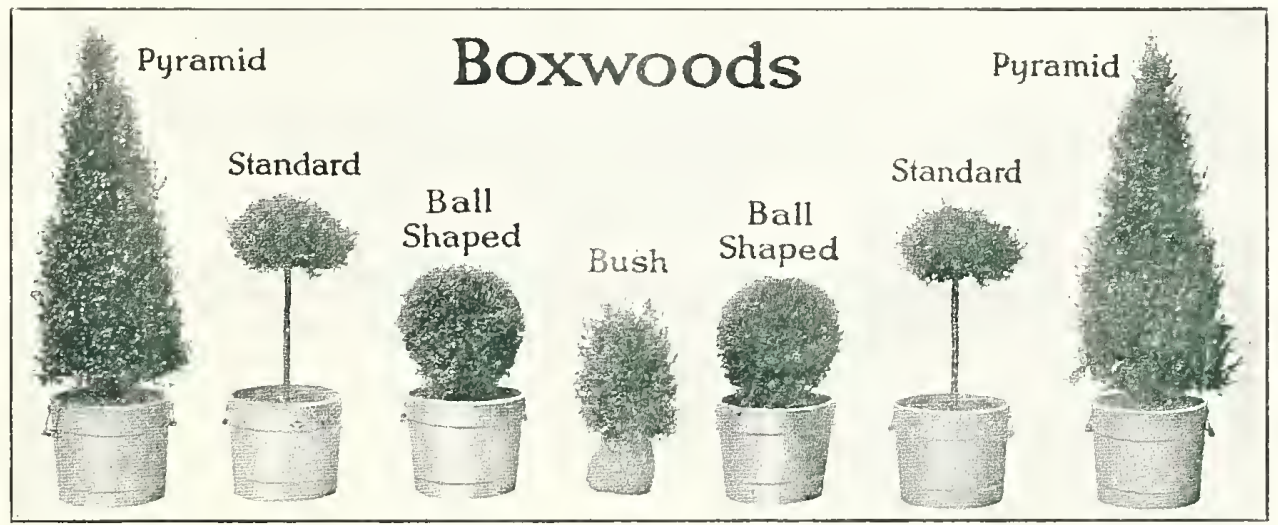

OLR BOXWOOD IS PROPAGATED FROM CUTTINGS NINE IP FROM SELECT SPECIMEN PLANTS GROWING ON GROLNDS OF OLD SOLTHERN VIRGINIA ESTATES. OLR STOCK IS LARGE AT ALL TIMES. WE SPECIALIZE ON BOXWOOD AND CAN FLRNISH MOST 


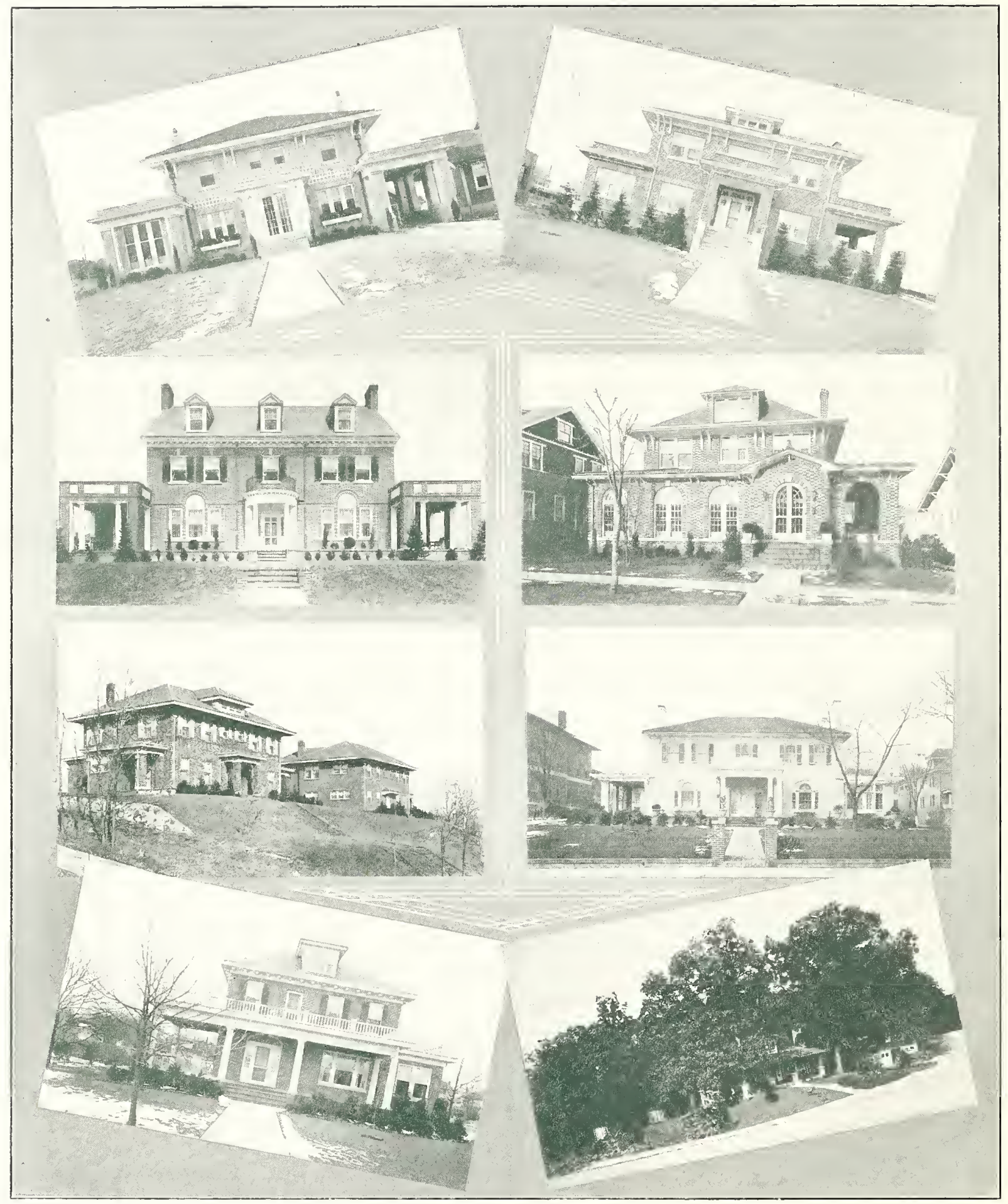

READING FROM LEFT TO RIGHT, THE FOLLOWING ROANOFE RESIDENCFS RECENTLY PLANTED BY HEDGE LATV NURSERY 1. DR. M S. JENKINS, 521 GREENWOOD ROAD, RALEIGH COURT, 2. W. R, HANCOCK, 913 GRANDIN
ROAD, IRALEIGH COUTT.

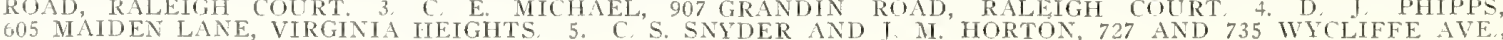
SOLTH ROANOKE, 6. R, R, FAIRFAX, 1131 SOUTH IEFFERSON STREET, 7. DR. T. M. WILLIAMS, 601 GRANDIN ROAD, RALEIGH COURT. 8, W. C WEAVER, GRANDIN COURT. 


\section{Rhododendrons}

Handsome, large-leaved, hardy evergreen shrubs that make effective foundation planting and frontline specimens for large-growing evergreen masses. They are the most imposing and attractive of all shrubs in foliage and when in bloom the most gorgeous. No other flower is so rich in bloom and color as the Rhododendron. No planting is complete without them, for they are attractive the year round and form a very pleasing mass of dark green color in the winter landscape.

R. Carolinianum. A new Americall species. Clear pink. Absolutely hardy. This is one of our finest introductions and fills a long-felt want for a hardy dwarf Rhododendron, with flowers free from any hint of magenta. It was described and naned by Alfred Rehder, of the Arnold Arboretum.

It is the smallest

Alleghanian species, attaining a height of six to eight feet in cultivation. The thick-set leaves are dark green, usually blunt and narrow. Much smaller than either Maximum or Catawbiense. Flower clusters appear in greatest profusion in June, covering the plant with a rose-colored mantle. Stands exposure unusually well and is invaluable as a single specimen or for massing.

R. Catawbiense. Of the Carolina mountains. The hardiest of all the Rhododendrons. It was this magnificent Rhododendron that, over a hundred years ago, was introduced into Europe-supplying, together with R. maximum, color and hardy blood to the cultivated "hybrids." Considering the extreme hardiness, color of flower, compact growth, and remarkable texture of foliage, which is a deep, shining green, and far superior to the better-known R. maximum, we can recommend the true native Catawbiense as the finest for general use, withstanding exposure and extremes of temperature where other Rhododendrons fail. Unlike R. maximum, it is a very free bloomer, with foliage of a

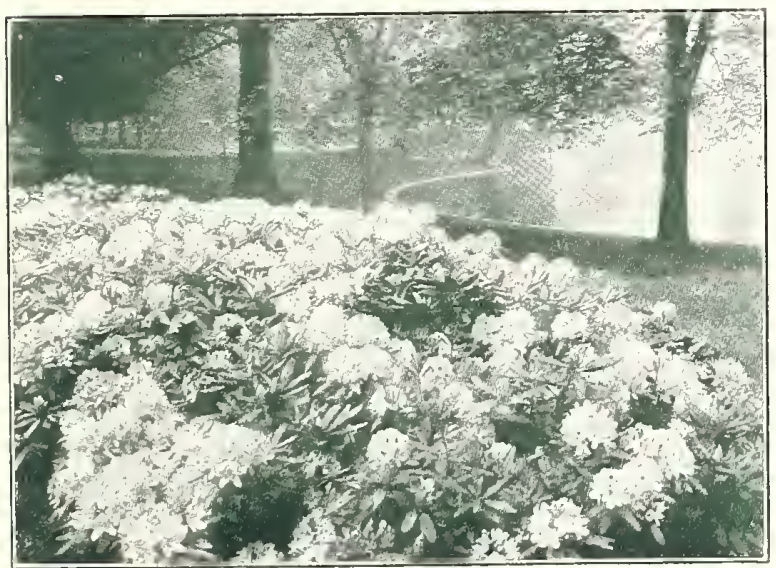

dark, rich, lasting green, which never rusts. The trusses of flowers are a bright red-purple.

R. Maximum. Great Laurel. A well known native of our mountain regions, with great white or rosepink clusters of flowers in June and July, just after the hybrid varieties have ceased blooming.

Specimen Rhododendron Catawbiense and Kalmia have diameter of spread about equal to height witl fifteen or more stalks to a clump, of height stated. 


\section{DECIDUOUS ORNAMENTAL TREES}

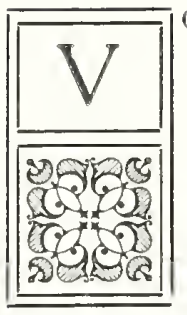

OLLMES could be written of trees, of their value and of their beauty. They are the oldest living things. To us they have been a heritage from preceding generations and common to all mankind we have an inborn love for them. They bring you natural beauty wherever used, whether it be on lawn, pasture, avenue or park. For shelter or shade, for fruit or blossom, for framing natural pictures, screening objectionable views, for backgrounds or seclusion they are indispensable.

Might we suggest a careful selection of what you plant? They all have some faults if not properly used. Some trees are rapid and some of slower growth. Plant for permanency the hardwood types. They grow a little slower but when you think of their longevity, beauty of form and foliage you will feel that you have made the better choice. If quick effect is wanted, interplant with the rapid growing varieties which can be removed when necessary. Plant them liberally and in groups, for they love companionship.

\section{Planting Suggestions}

Plan to plant permanent trees thirty feet apart and those not so robust at twenty feet. Where quick growing trees are interplanted fifteen to twenty-five feet is suggested.

Be very sure to prune all shade trees at time of planting. This should consist of shortening the side branches, taking off, generally, the last season's growth or more. We prefer not to dehorn the tops but rather shorten the central leader in proportion to the pruning done on the side branches. Avoid making crotches, if possible, as trees later may break under ice or wind. We strongly recommend wrapping the bodies of all trees with some protective material, like burlap, paper, etc. Under our southern sums you are very likely to have badly scalded trees on the southwest side, near buildings or pavements, the reason being they are closely grown in the nursery row and there have the protective shading from the neighboring trees and the trunks are consequently tender. Lsually after the second year you are safe in removing protection.

Mulching is very fine, too, to conserve the moisture. In exposed places it should be applied only in the spring on newly set large trees as it keeps the ground from freezing and the wind and weather sway the bodies, making air pockets about the roots. On small trees apply at any time.

In watering on the surface remember to give copiously as shade trees are planted much deeper than the other plants you are ustally accustomed to watering. Tilling is especially fine because in this way you get the moisture down ten or twelve inches where the active root system can quickly take it up. EXPENSE.
ASH, American. Fraxinus americana. A stately native tree, with straight clean growth, foliage light green. Dependable and very satisfactory as it grows rapidly, being a forest tree valuable for timber.

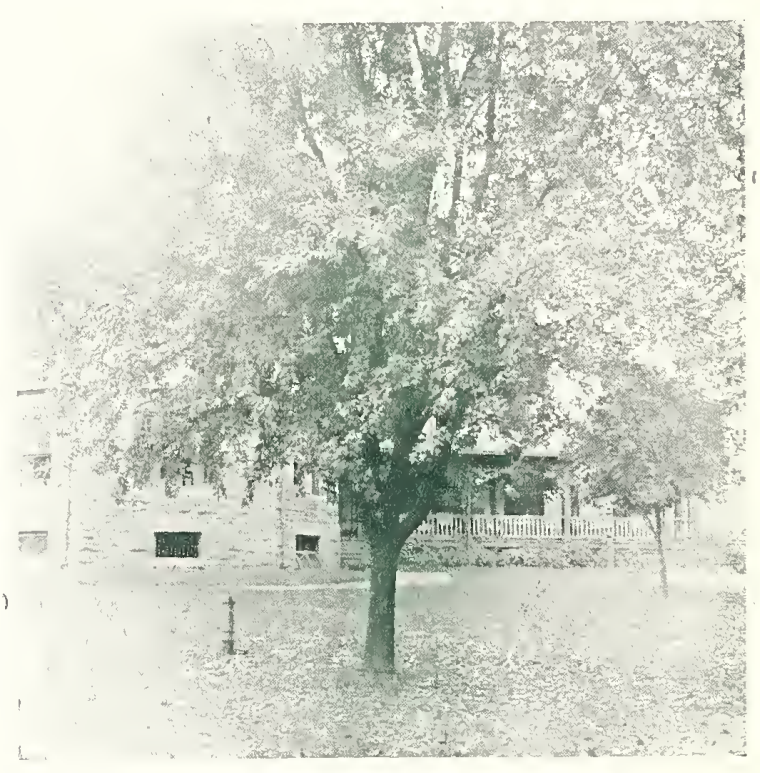

WHITE ASH

BEECH, European. Fagus sylvatica. The foliage is a silvery green, the young growth and under side of the leaves being especially noticeable. Holds the foliage well and colors vividly in fall.

BEECH, Purple. F. sylvatica purpurea. Thus called because of its especially dark purple foliage. In the spring, when first in leaf, the richness of its color must be seen to be appreciated. In midsummer it holds its color well but changes to a crimson in the fall. For brightening dull shades in shrub borders, planted as specimens on the lawn or in foreground of light colored buildings for contrast, it can be highly recommended.

BIRCH, European white. Betula alba. Tree of moderately quick growth, bark almost white, erect growing with terminal branches slightly drooping. Native of moist places but will do well when planted on dry ground. As a specimen tree and especially contrasted with evergreens it makes a valuable tree for the lawn.

THIS HOUSE WOULD STAND OUT BARF AND BOLD WERE IT NOT FOR THE SHADE TREES THAT FRAME IT AND GIVE IT THE PROPER BACK. GROUND. SUCH ADDED BEAUTY, WITH THE RESULTANT COMFORT OF SHADE UPON THE LAWN, INCREASES REALTY VALUES. MAKING SHADE AN INVESTMENT, RATHER THAN AN
BIRCH, River, B. nigra. This is a native tree with darker bark but in foliage and general characteristics resembles the other Birches. 


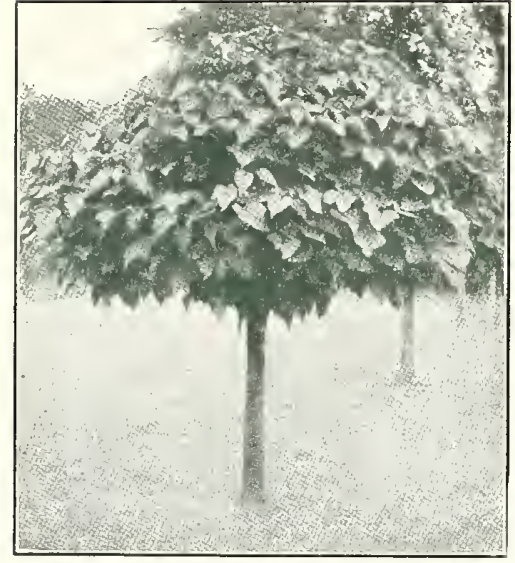

CATALPA BUNGEI

BIRCH, Weeping, White. B. pendula gracilis. This tree is one of the most conspicuous trees grown With its white bark, deeply cut leaves and long, pendant branches it presents a picturesque effect planted either as a specimen or otherwise. It should be pruned severely when planted and once established will prove of great merit.

BIRCH, Purple. B, pendula purpurea. Tree is a typical Birch; bark a dark hue and the leaves purple in color. Branches follow the general Birch habit-drooping gracefully.

BUTTERNUT or White Walnut. Juglans cinera. This native tree is perhaps the most precocious of the nut bearing trees. In growth it is rapid, making a round-headed tree. If you want nuts quickly, plant Butternuts.

CATALPA, Umbrella. C. Bungei. This tree has become popular because of its straight stems and symmetrical roundish heads which resemble an umbrella. The tops are dwarf and while they do not grow very rapidly their wide leaves give then the appearance of much larger trees. The foliage is very pleasing and the effect obtained when planted in pairs along walks, drives or entrances is greatly admired.

CATALPA, Western. C. speciosa. This is a tree of very quick growth and thousands of seedling trees have been planted for timber. The growth is astonishing when planted on moist land, but thrives on higher and poorer soil. The tree in June is a mass of white bloom and, therefore, highly desirable when flower effect is desired.

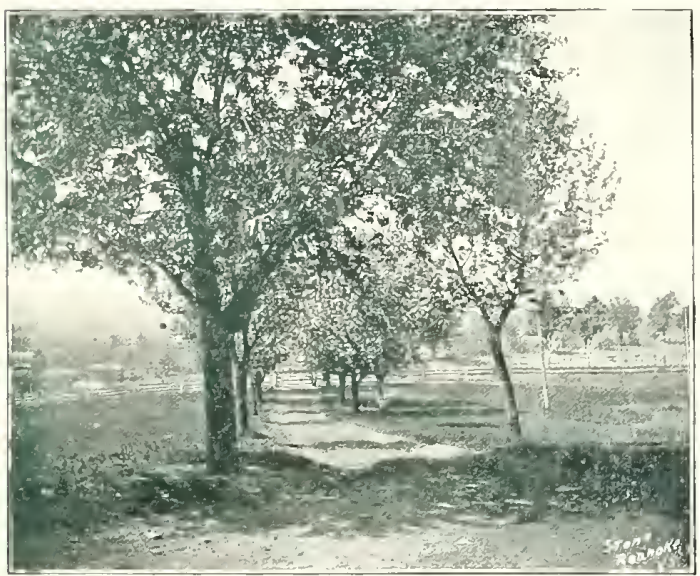

OHIO BUCKEYE
DOGWOOD. White Cornus florida. A native tree well known to everyone. There is hardly a woody plant that grows that is quite as useful as our native Dogwood. Its blossoms are conspicuous, coming early in the spring, the foliage is attractive all summer and in the fall colors beautifully with red berries that hang on most of the winter. It is beautitul at all seasons of the year. It can be used as a specimen or in groups, as a background for shrub borders and when planted in contrast with bright flowering plants like Redbud it is especially showy.

DOGWOOD. Pink. C. florida rubra. This is a colored form of the above native sort, resembling it very closely in habit of growth, period of bloom and general behavior. Conspicuous in the early spring with bright deep rose blossoms.

ELM. American. Ulumus americana. I tree of unusual vigor, a native too well known to describe. It is rapid of growth, with its long, spreading and pendant branches forming giant arches over roads and streets or as a lawn tree is quick to make a marked effect. The wood is tough, the leaves are moderate in size and makes a permanent tree for shade. The beetle that defoliates the European Elms usually avoids these.

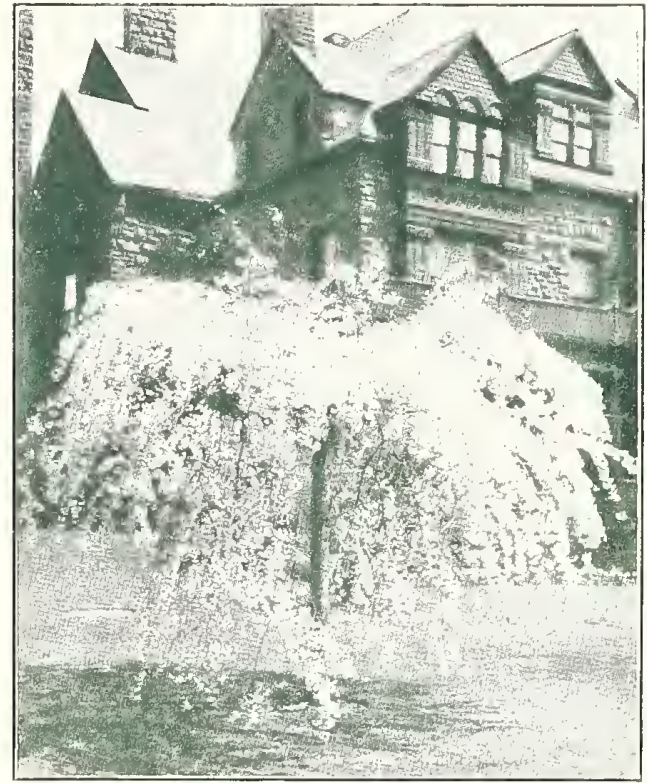

JAPAN WEEPING CIIERRY-A FOUNTAIN
OF ROSY BLUOM

ELM. Cork-barked. U. foliaca suberosa. This has all the characteristics of the native Flm except the bark is very unusual, being in prominent ridges along the trunk and branches. Rather an attractive tree in winter time becanse of this unusual characteristic.

GUM, Sweet. Liquidambar sytaciflua. Another native tree not appreciated. It is not of rapid growth nor especially easy to transplant, but the glossy foliage in summer, the brilliant color in the fall and the nnusual appearance in the winter of the young branches with their corky bark are considerations that make it especially valuable.

HORSE CHESTNUT, European. Aesculus hippocastanum. A tree of slow growth, yet very attractive in its roundish form with large leaves that are conspicuous in early summer. It is especially valued for the long panicles of flowers, white and tinged with red. 
KENTUCKY COFFEE. Gymnocladus dioica. Native to Kentucky. Very blunt, sturdy branches, inconspicuous buds developing into frond-shaped leaves. giving the tree a more tropical appearance than any other native. Flowers inconspicuous but superbly fragrant.

LARCH, European. Larix europaea. Like the Cypress it is a deciduous tree bearing cones like evergreens. The foliage in very fine, needle-like, appearug earlier in the spring than any other tree and atays until very late fall. The tree is a perfect pyranid in shape, holds its contour until maturity. Very conspicuous because of bright green color, unusual needles and branching habit. We recommencl it for city planting also, as the foliage does not seem to be affected by smoke or dust.

LINDEN, American or Basswood. Tilia americana. This native tree is very attractive and will grow rapidly when planted in low ground. The leaves are dintinctly larger than other varieties, branches pendulons in habit of growth and makes an excellent shade tree under favorable conditions.

LINDEN, European. T. vulgaris. A very compact, pyramidal tree, of dark green foliage, easy to transplant and very satisfactory for avenue or lawn planting. Leaves are large, heart-shaped, the branches are smooth and tough and when the tree blooms, which it does profunely, the fragrance is noticeable for considerable distance.

MAIDEN HAIR. Ginkgo biloba. A conifer but deciduous. It is allied to the P'ine family. On close examination of the leaves one will note the aborted Pine needles bound together into a solid leaf. It is of Asiatic origin and carries with it the indescribable oriental appearance in the shape and ponition of its branches, leaves, character of growth and color of bark. Perfectly hardy; here and in the East largely used for avenue trees.

MAPLE, Norway. Acer platanoides. A tree resembling the Sugar Maple in character, but of darker and larger foliage, round and spreading in habit of growth. It is really the European Hard Maple and retains this character here. For lawn, as specimens or shade, to plant on streets beneatl wires or for spearling over sidewalks, parks, cemeteries or for avenue or arching over roadways thin tree is highly recommended. Sometimes the trunks are inclined to be slightly crooked when young, but it is well known that they grow out of this unsightliness in a few years when planted in the open.

MAPLE, Red. Acer rubrum. If it were not for the crooked trunks of this tree, as a lawn specimen it would prove mont attractive. The young hoots are bright red in winter, blooming in early spring, a very brilliant color, with pleaning foliage until frost. Then it vies with the Oakn. Sassafras, Gum, Sumac or Sugar Maples for magnificence in color.

MAPLE, Schwedler's. Acer platanoides schwedleri. A tree resembling the Norway Maple in every respect except in early spring the foliage is a bright purple, changing from bronze to dull green. In the fall it turns bronze before defoliating.

MAPLE, Silver or Water, Acer dasycarpum. Because of its quick growth, gond foliage and ease to tran-plant, this tree is in great demand. The tree blooms very early in the spring: leaves appear promptly, being light green in color but silvery beneath, and these remain until late fall. For planting as temporary trees-that is, alternating between the hardwooded and slower growers as Uaks, Elms, Sugar Maples, Gum, etc., this variety is highly recommended.

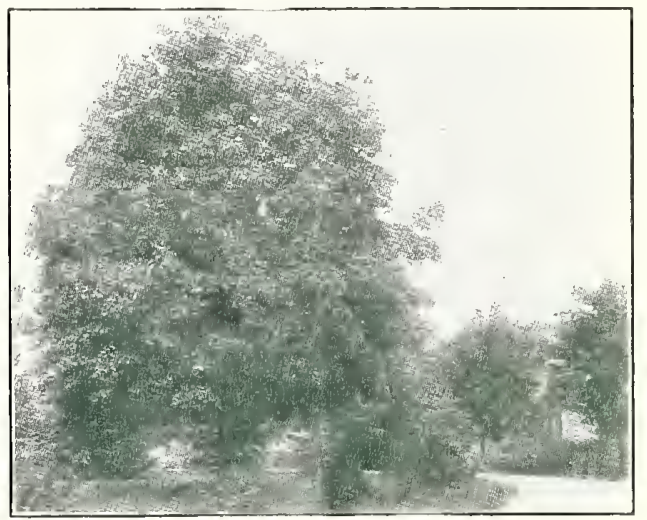

NORWAY MAPLE

MAPLE, Sugar. Acer saccharum. Known everywhere and is so popular that it is difficult to keep a well-grown supply on hand. Tree grows to be of great size, foliage of good color and in the fall turns indescribably to all tints imaginable. Being of erect, conical growth, perfectly hardy and wood of such texture that it will survive any abnormal condition of the weather and its adaptability to all types of soils makes it a variety justly popular. Native grown, it proves valuable for the timber for hard wood finishing and also "tapped" for maple sugar.

ACER PALMATUM. Japanese Maple. Handsome shrubs or flwarf trees, valuable for planting as single specimens, grouping on the lawn, or in beds near buildings, giving a most pleasing color-effect.

PALMATUM. Green Japanese Maple. This is the parent of all the Japanese varieties. The small green leaves are not so deeply cut as those of some varieties, but the foliage is a bright green in the spring and summer and makes a gorgeous showing in the autumn, when it assumes rich tones of yellow and scarlet. 15-20 feet.

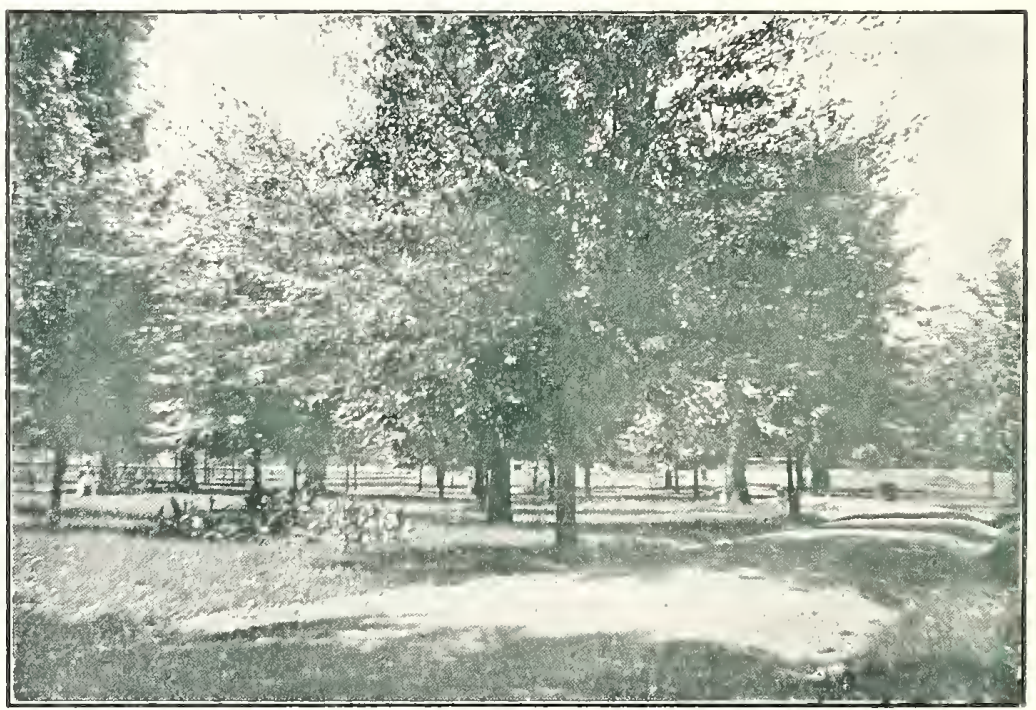

A BEAUTIFUL GROVE OF NORWAY MAPLES 
PALMATUM ATROPURPUREUM. Blood-leaved

Japanese Maple. In the spring the star-shaped foliage is a dark red, turning to purplish red and retaining that color most of the season. Probably the best, and certainly the most popular, of all the Japanese Maples because of its effectiveness when placed where it has a background of green foliage. Makes a bushy specimen 10-15 feet high.

MULBERRY, Russian. Morus tartarica. This makes a roundheaded tree, quick of growth and very profuse foliage. It is wonderfully productive of fruit and for anyone wishing to attract birds this tree cannot be surpassed. If planted in chicken runs it will produce fruit for several months. The fruit is considerably smaller than our native rariety but the tiee bears so profusely that it is visible for a considerable distance.

\section{MULBERRY, Weeping. Morus}

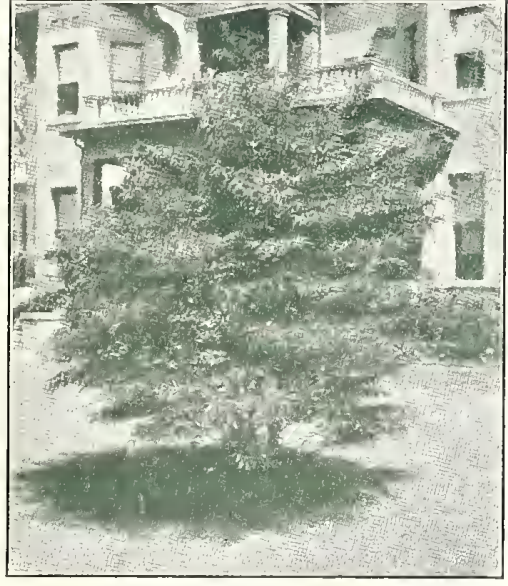

RED LEAF JAPANESE MAPLE plantings or to offset straight or bare lines. Further, for screening unsightly views, fire protection from clone buildings or wind breaks-and all for quick effect, we unhesitatingly recommend this variety. A false impression prevails that it sheds its leaves early, but this is a misapprehension, as the tree is healthy in growth and foliage.

PECAN. Hickoria Pecan. There has been a great deal said about these of late but on our soil conditions they are very hard to establish and exceedingly slow of growth. They are hardly worth trying on limentone soil and unless you have more favorable conditions than in Central Virginia they will be disappointing We have found the seedling trees to be more vigorous than the budded varieties where favorable locations are to be had. For fruit there is no comparison as the named varieties are much superior and we would advise alba pendula. A very old tree, immediately attractive with its long, sweeping branches that touch the ground. It is grafted on its parent stock-Russian Nulberry-and is entirely free of all disease and bears some fruit.

OAK, Pin. Quercus palustris. Of all the Oaks this is preferred. Perfectly symmetrical from the

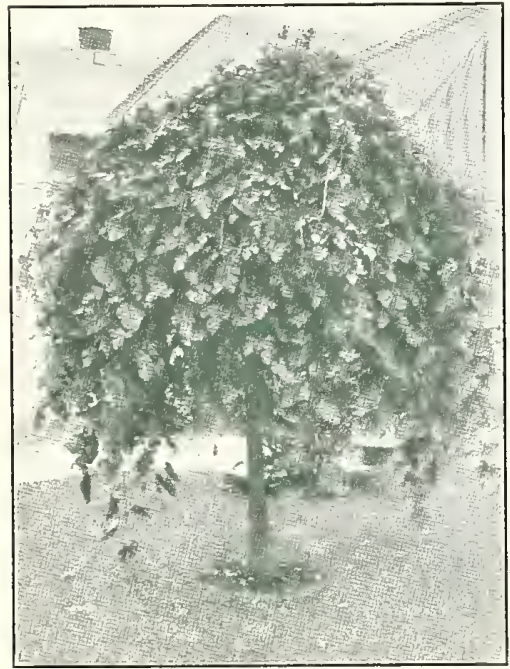

WEEPING MULBERRY base branches up, foliage a shining green, leaves deeply cut and in fall of wondrous colors-a combination for beauty, symmetiy and dur ability not found in any other tree. It is the easiest of the Oaks to transplant. more rapic of growth and in any capacity a tree may be used, whether shade, specimen, avenule, cemetery or park tree, if one is a little patient the reward is commensurate. We are very partial to it and when a hardwood tree is wanted for any location we unhesitatingly recommend Pin Oak. If you knew it as we do you would be equally enthused.

POPLAR, Lombardy. Populus nigra italica. A tall, slender tree reaching great heights, very easy to transplant and of most rapid growth. Specimens often reach fifty feet with a spread of less than ten feet, and for this reason when tree plantings are needed for narrow places, between buildings, congested lawns, narrow avenues, this may be used with great satisfaction. Because of its great height and quick growth it is commendable for hackgrounds of buildings, to add character to the purchase of these if you wish to experiment with them.

REDBUD or Judas Tree. Cercis canadensis. A native of our woods, literally covered with its red or pink blossoms early in the spring before it opens its leaves. It is an early harbinger of spring, blooming in April. It is a small, shapely tree, wood very tough, and the leaves large and very green in color. It may be used in heavy mass planting of shrubs, with White Flowering Dogwood or against evergreens or White Birch, making a pleasant contrast.

SYCAMORE, American or Plane Tree. Platanus occidentalis. A native, sometimes thought too common to plant. However, where a tree for quick effect is wanted, one clean in habit of growth, luxuriant of foliage and easy to transplant, this lesson of Nature in distributing it so liberally should be accepted. The bark is silvery or grayish in winter, the leaves hold on well and for avenue, street, lawn and paddock shade, the Sycamore can be satisfactorily used.

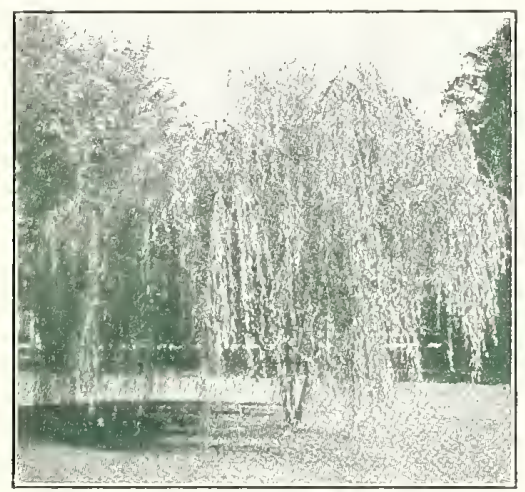

WEEPING WILLOW

WILLOW, Weeping. Salix babylonica. A tree of stately appearance with long pendant branches swaying their silvery foliage in every breeze, quick to take hold when transplanted, will give a finish to a lawn not obtained in any other tree. This, too, makes a good screen and whether planted on moist or dry ground thrives with unusual vigor. 


\section{DECIDUOUS FLOWERING SHRUBS}

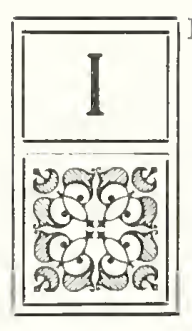

diversity of form, variety of species, contrast of foliage and variation of blossom this group holds unusual interest and as a group they prove to be the finishing touches or tints of virtually all landscape plantings. With trees we have made our bolder outlines and shaded the grounds but to this group we come to soften the borders or edges of drives, walks and boundaries; to emphasize some lawn feature; to mellow rigid lines or sharp angles, to fill depressions, to screen objectionable views; to cover slopes or divide areas. From early spring, yes, even late winter, they unfold their wondrous bowers of yellow, pink, white and red flowers on backgrounds of purple, yellow, light and dark green foliage. The attractive fruits and berries often adhere after autumn has spread its brilliant colors on the foliage. Proper selection as to height and careful choosing of varieties will insure the accomplishments mentioned and provide a source of indescribable pleasure to the home owner.

NOTE-In the descriptions that follow we give height at maturity, color of blossom and period of bloom. Those specially recommended for foundation planting are thus designated (F). A table, too, will be found on Page 47, suggesting plants for various and special locations.

\section{Planting Suggestions}

There is always a tendency to over-plant in the attempt of immediate effect. Don't be impatient as it takes several years to grow mature plants. So, in planning your requirements, here is a general rule to apply-on real good soil the spread of a shrub usually approximates the height, in other words, a five to six foot shrub will just about spread that much.

\section{About Planting}

Dig holes and plant as deeply as they stood in the nursery row. Shake the plants so the soil will sift into the roots. Some shrubs have great masses of fibrous roots that if the soil is merely thrown on top, they will surely die. Contact with every root insures growth, so work the earth carefully through these masses. In pruning take off about one-half the tops; at least a third. If you haven't read General I'lanting Instructions, refer to I'age 3.

The pruning after development causes confusion. "Prune when the knife is sharp," has long been a saying and no shrub was ever killed by pruning.

However, one time is better than another and unless otherwise necessary you will find that the best results are obtained by light pruning immediately after the blossoms fall. Heavy pruning at any time will cause the plants to put aside their blossom-forming buds and make wood growth and you lose or lessen the next season's blossom. That is why light pruning is suggested annually or biennially. Pruning in the dormant stage is not injurious and some plants can be so much better shaped when the branches are defoliated. In all pruning do not bob off the tops and make hedges of your massed plants. This causes a new "break" or ugly offset giving them a two-story effect. Shorten the canes to a side branch so that it will develop all the natural pendancy or other characteristics of the plant. To remove canes, cut close to the crowns as this causes them to renew naturally from the bottoms. Now for the perpetual exceptions-all terminal blooming plants like hydrangeas, hypericum, bush roses, etc., that bloom on the "tips" of the new growth need severe pruning if large blossoms are wanted. Constantly renew this young wood by pruning in the dormant and semi-dormant period only.

ALMOND. Pink-flowering Almond. Prunus glandulosa. (F.) 3-4 ft. Rose-pink. April. Very attractive shrub. The plants are usually thickly studded with double pink flowers of medium size from base to tip of branch. The plants are usually propogated on plum or peach stock as it belongs to this family and should be planted deeper than ordinarily advised for other shrubs.

ALTHEA. Rose of Sharon. Hibiscus Syriacus. These are tall slender shrubs that do well under congested city conditions and other places where some of the woody plants fail to grow. The blossom period usually starts in July and extends to September. Altheas are greatly used for hedge and screen purposes. Please note they may be bought to color.

Single White. Blossoms white with pink center. Single Pink. Selected for clear deep pink blossoms. Double White (Jeanne d'Arc). This is a pure white, double-flowering variety. Very attractive.

Double Red (Boule de Feu). Freest blossoming of all the doubles. Very attractive; bright in color.

JAPANESE BARBERRY. Berberry Thumbergii. (F.) 2T/2-3 ft. Yellow. June. This, without a doubt, is the most valuable all-purpose shrub offered to-day. It really hasn't a serious fault and can be used wherever a plant of this size is desired. Grows in semi-shady, moist or dry locations. When used as a specimen plant or as an edging plant for borders, foundations or hedges, its drooping habit, deep

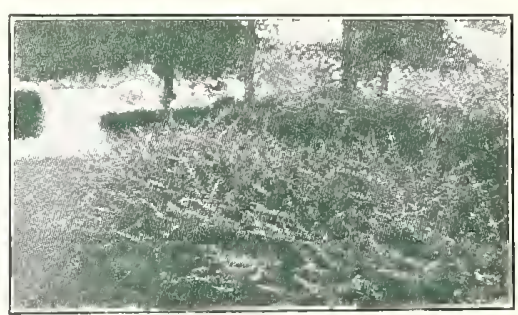

BERBERRY THLMBERGIT. MUCH USED AS HEDGE OR SINGLE PLANTING

green foliage in the summer months and red berries that liang all winter, are attractive. We grow large quantities of this and unhesitatingly recommend it to every one that desires a hardy, thrifty plant that will adapt itself to soil conditions under most trying circumstances. Does not carry wheat rust.

BUTTERFLY BUSH, or Summer Lilac. Buddleia Davidi. 4-6 ft. Violet. July-September. A very attractive new addition to the flowering plants. While a perennial in habit, yet, because of its vigor and size, it is used largely in shrub plantings. The tops in severe winter will freeze back, but it pushes with such renewed vigor this is not harmful. The flowers are borne on the tips of every bit of new growth, and in August the plants 


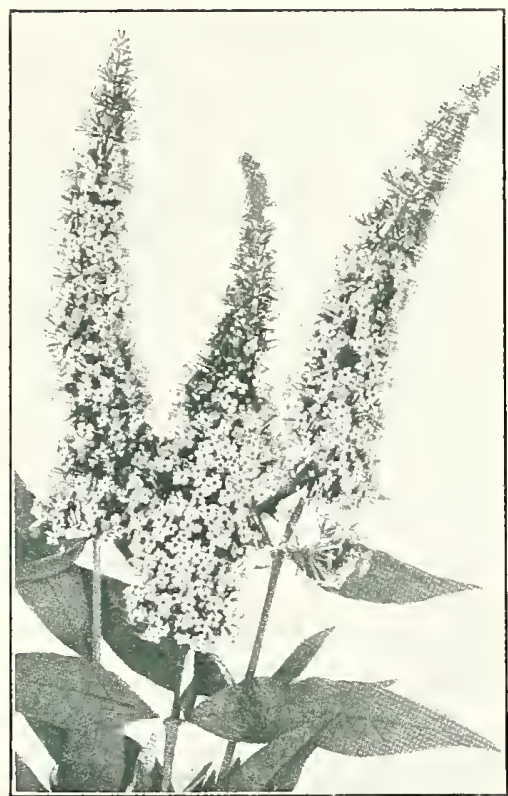

BUTTERFLY BUSII

are masses of very conspicuous purple and violet flowers that attract butterflies.

CALYCANTHUS floridus. Sweet Shrub or Allspice. (F.) 4-5 ft. Chocolate brown. This is an oldfashioned shrub well known to everyone. It blossoms intermittently all summer and its flowers are usually very sweet scented.

CORAL BERRY or Indian Currant. Symphorocarpus vulgaris. $4-5 \mathrm{ft}$. June. This is a native shrub that in many localities grows in great masses. It is very hardy and easy to establish where other things fail. Its beauty lies in the wonderful wealth of coral berries that come in late summer and usually adhere all winter.

CRANBERRY. Highbush Cranberry. Viburnum opulus. 8-10 ft. White. May. This plant belongs to the Snowball family and is unusually attractive because of its bright berries that attract birds in mid-summer and also for its color effect in the fall. The flowers are inconspicuous. This is one of the best things for natural planting but owing to scarcity of stock it has not been largely used.

CRABS, Bechtel, Flowering. Malus ioensis plena. $10 \mathrm{ft}$. Pink. May. This is an unusually attractive tree in full blossom; flowers being fragrant, double, resembling a miniature rose. The foliage is very much like an ordinary apple tree but there is no plant in the catalogue that is quite as attractive as it is when in full blossom. Rather slow growing and more expensive than ordinary shrubs but well worth the space it occupies.

CRABS. Single Japanese. Malus florabunda. 10-15 ft. Deep rose. May. This is a single blossom borne in large clusters and inclined to be drooping. The flowers are considerably smaller than the Bechtel, but showy, because of its very deep color and mass of blossom. It has never been plentiful in the nursery trade.

CRAPEMYRTLE. Lagerstroemia indica. Familiar to everyone living in the South. It has small, very dark green shining leaves and blossoms in August and September in panicles of peculiar but attractive flowers. Can furnish pink, red and purple.
DEUTZIA. D. Scabra candissima or Snowflake Deutzia. 6-10 ft. White. June. A Japanese shrub noted for its hardiness, fine habit of growth and profusion of attractive flowers which are borne in racemes. The small flowerettes resemble double Lily of the Valley. Where quick effect and screen is wanted this is a very desirable plant.

D. gracilis. Slender Deutzia. (F.) $1 \frac{1}{2}-2 \frac{1}{2} \mathrm{ft}$. White, May. This is a dwarf shrub, very dense in growth. blooming profusely in small racemes on arching branches. Sometimes caught by late freezes but in protected places can be used as a low growing shrub for border planting. We have some trouble occasionally, it being troubled with leaf spot and mildew.

D. Pride of Rochester. D. Scabra. (F.) 6-8 ft. Pinkish white. June. This variety is very much the same as Deutzia candissima, but is more popular on account of its color. It is very hardy, adapting itself to any type of soil and if better known would be one of the most popular shrubs planted to-day.

DOGWOOD. Cornus florida. White Flowering Dogwood. 15-20 ft. White. May. This is really a small tree and should be classed with shade trees. Description also appears on Page 23. As a hackground for shrubs this and Redbud are largely used. We hardly know of a plant that is quite as attractive in all seasons of the year as our native Dogwood.

DOGWOOD. Blood-twig Dogwood. C. Sanguinea. 7-8 ft. Greenish white. June. This is a true Osier, being adapted to moist places. It is a strong grower. The stems of this variety are deep red and are very attractive in winter.

DOGWOOD. Red-twigged Dogwood. C. sibirica. 6-8 ft. Greenish-white. June. Not so robust a grower as the preceding, but branches are brighter red color in the winter, making it even more attractive at this season. Pruning the old wood out to encourage new growth increases its brilliancy of color when used in conspicuous places.

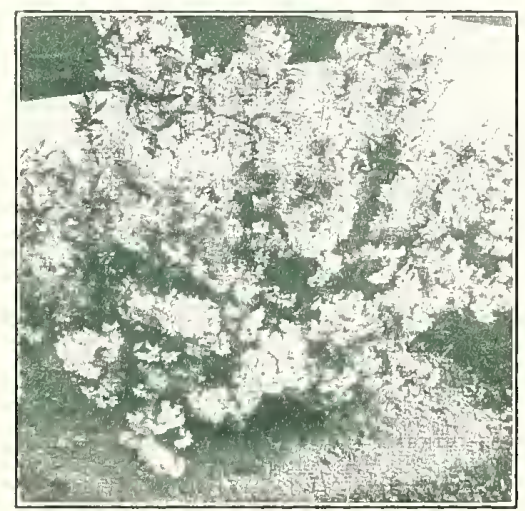

DEUTZIA GRACILIS

ELDER. Golden American. Sambucus canadensis. 8-10 ft. White. July. This is one of the best foliage plants grown under southern conditions. It holds its bright color the entire summer and is very conspicuous in a mass planting. It has the usual Elder blossom of large size and this is followed by a very attractive berry. All Elders are quick to establish themselves and do well on all types of soil. 
EXOCHORDA, or Pearl Bush. E. grandiflora. 8-10 it. White. April. This is a plant that is not as well known as it should be. It is one of the most pleasing of the early spring flowers, being a mass of blossom during April. The leaves are light green, of unusual construction and in mass planting hould be used extensively. Prune severely at planting time for best results.

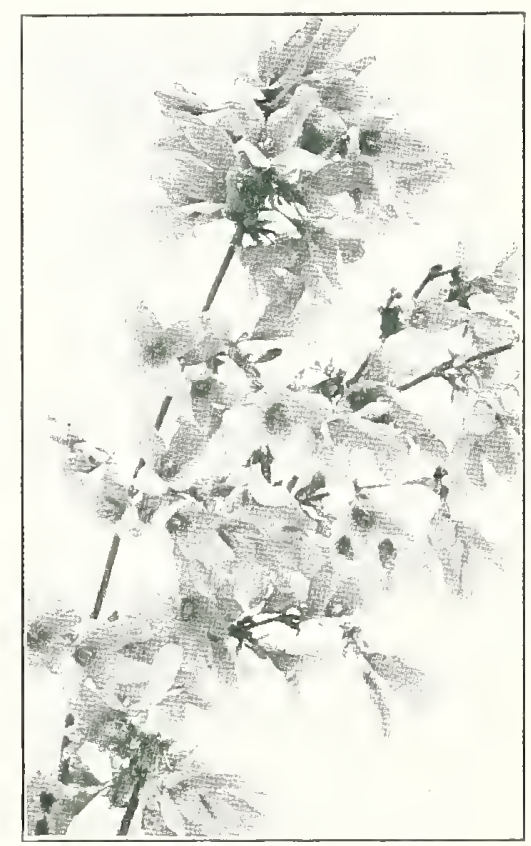

FORSYTHIA FORTUNEI

FORSYTHIA or Golden Bell. F. viridissima. This is often called green-stemmed Golden Bell. 6-8 ft. Yellow. April. This is decidedly the most popular of all the Golden Bells. The Howers appear before the learen and the plant makes a great show early in the spring.

Fortune's Golden Bell. F. Fortunei, 6-8 ft. Yellow. April. A form of $F$. suspensa, but with more upright branches and darker, heavier foliage.

Forsythia suspensa or Drooping Golden Bell. 6-8 ft. Yellow. April. A drooping variety that makes a desirable bush when planted alone or can be made to arch trellises, etc.

HYDRANGEA, Snowball, H. arborescens grandiflora. (F.) 3-4 ft. White. May and June. (Also called Hills of Snow, Summer Hydrangea or Snowball Hydrangea.) This magnificent hardy American shrub is the very finest addition to this clans of plants found in many a year. The blooms are of the very largest size, of pure snow-white color and the foliage is finely finished. One of its most valuable characteristics is its coming into bloom just after the passing of the early spring shrubs; while its long period of bloom from early June through August, makes it doubly valuable not only to the florist but to every owner of a garden. Perfectly hardy. Habit of plant excellent.

HYDRANGEA, Old-fashioned. H. paniculata grandiflora. (Great Panicled Hydrangea.) (F.) 4-5 ft. White. August. Commonly known as Hardy Hydrangea. This popular variety does not bloom until August and September. The large spikes are first greenish white, then pure white, later changing to bronze pink.

HYPERICUM. St. John's Wort or Gold Flower. H. moserianum. (F.) 1-2 ft. Yellow. July to September. This rather unique low-growing shrub always attracts attention. Flower a beautiful rich yellow, borne on slender stems, surrounded with rather roundish, leathery green leaves throughout the smmmer. During severe winters it often kills to the ground but next spring will come back more vigorous than before.

HONEYSUCKLE. Fragrant Bush. L. fragrantissima. (F.) 7-10 ft. White. April. So called because of its very fragrant blossom. The foliage is very deep green and glossy. This grows well in partial shade, in adverse soil or in cities where tender plants fail. Because of its nearly evergreen habit it is being largely used for hedges. Without doubt one of the very best plants for landscape purposes grown to-day.

HONEYSUCKLE. Morrow's Honeysuckle. L. morrowi. 8-12 ft. This is one of the best quick growing, compact and "filler" shrubs we have. The foliage is bright green, the blossoms cream colored, appearing in April. The red and coral fruits follow from June to August. In dry or moist soil, shade or sun, city or country, this variety will thrive.

L. tatarica. 7-9 ft. Pink. April. This is very attractive in blossom, being one of the few early pink flowering shrubs. Has bright red berries that stay on all summer.

JAPONICA. Japanese Quince or Flowering Quince. Cydonia Japonica. 6-8 ft. Scarlet. April-May. No doubt one of the most attractive spring blooming shrubs. Blossoms always large, produced in great masses just as the leaves are coming out. Foliage is a dark, glossy green. If it can be kept free of San Jose scale will pay for the space it occupies in any planting.

LILAC. Common white. Syringa vulgaris alba. 6-8 ft. April. No shrubs are better known than the Lilac. This is the old-fashioned white that every one knows.

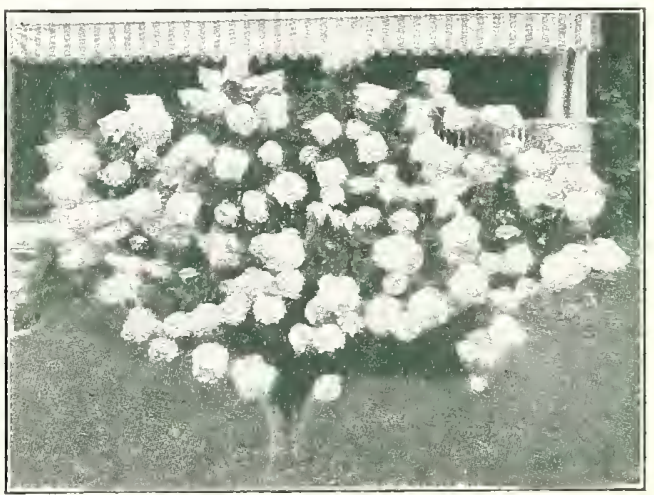

IIYDRANGEA PANICULATA GRANDIFLORA

LILAC. Common purple. S. vulgaris, 7-10 ft. This is the old-fashioned variety always so familiar in our grandmother's garden. Usually more vigorous in growth than the white variety.

LILAC. French. These are the very much improved variety sold to name and color. They bloom unusually soon after planting and their large trusses of blossoms are very attractive. They are more 


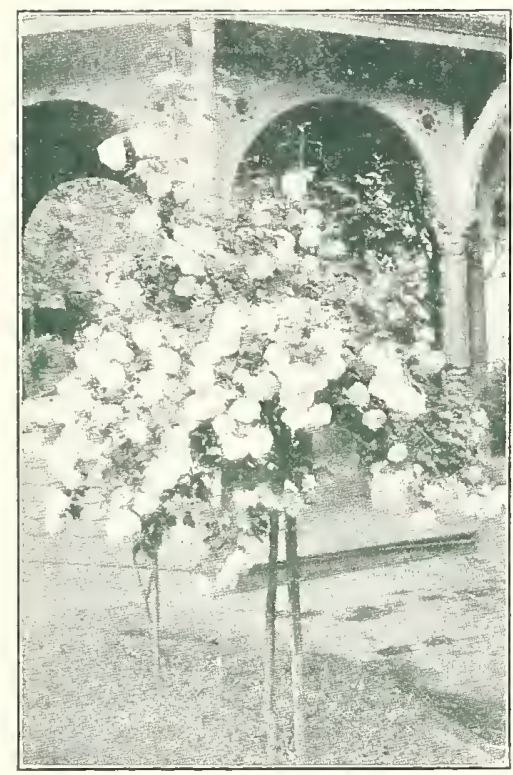

OLD FASHIONED SNOWBALL

expensive than the common variety but where space is limited are certainly worth planting.

MOCK ORANGE or Syringa. Philadelphus coronarius. Sweet Mock Orange. (F.) 6-8 ft. White. June. The old-fashioned mock orange, well known to everyone because of its waxy white, fragrant flowers. It proves a specially good plant for every use, the foliage being large, oval in shape and deep green. For cut flowers it is valuable and pruning in this manner often keeps the bush confined where it is not desirable to have it grow too tall. Very valuable for background, screen or grouping.

MOCK ORANGE. P. grandiflorus or large flowering Mock Orange. 7-10 ft. White. June. This is a more vigorous grower than the preceding but lacks the fragrance. Blossoms are larger and very attractive. Where a tall plant is wanted there is hardly anything better than this. Succeeds under all.soil conditions.

PRIVET Amur or Amoor. Ligustrum amurense. (F.) 6-10 ft. White. June. A small leaved, almost evergreen, variety of Privet that is much used for hedges but also very desirable for landscape work because of its unusual rapidity of growth, good foliage and graceful branching. It is not particular about soil and for semi-screening and mass planting is unexcelled. It is not used enough as a shrub. We are very partial to its use in the South. Hardy where California Privet will succeed.

PRIVET Ibota. L. ibota. 6-10 ft. This is another of the Chinese type, resembling Regel's Privet very closely but being more erect in growth. Its bronze foliage in the fall and attractive berry make it valuable. Then, too, its hardiness and ability to withstand not only severe weather, but adverse weather conditions, make this and Regel's Privet a very desirable plant for mass planting.

PRIVET. Regels. L. ibotum regelianum. (F.) 5-7 $\mathrm{ft}$. White. June. A low, spreading variety being very twiggy, with a dense foliage not so glossy as California. Because of its graceful appearance, hardiness and adaptability to any soil and shady places, it is the most widely used Privet for landscape work.
RHODOTYPOS or Jetbead. R. kerriodes. (F.) 4-5 ft. White. Nay and June. Very ornamental shrub with bright green, plaited leaves and large white flowers one-half to one inch across. These are produced in the end of the branchlet and are followed by conspicuous shining black fruit that adhere practically all winter. At desirable shrub.

SNOWBALL. Common. Viburnum o. sterile. 10-12 $\mathrm{ft}$. White. May. This old-fashioned variety is well known to every lover of plants. Its balls of pure white, literally cover the bush when in bloom.

SNOWBALL. Japanese. Vib. tom. plicatum. (F.) 6-8 ft. White. Mlay. This species is one of the most satisfactory shrubs grown. Its pure white. double blossoms with a setting of dark plaited leaves and perfect form make it one of the best. Fine for an individual specimen or in groups.

SNOWBERRY. Symphoricarpos racemosus. (F.) 4-5 ft. This shrub has small pinkish flowers in July, followed by white berries which remain on well into the winter. Very attractive merlium growing shrubs.

SPIREA. S. Anthony Waterer. (F.) 2 ft. Bright pink. June and July. A compact, low-growing shrub with dense foliage usually deep green with occasional variegated leaves of pink and white on young growth. Flowers are borne in full, flat clusters on erect stems. If these are cut away when they fade the hrub will usually bloom intermittently during the summer. Very valuable for edging in front of hrubbery or sometimes used as a dwarf hedge.

S. callosa rosea. (F.) 3 ft. Deep pink. June-July. Really a taller form of Spirea Anthony Waterer. A little more open in growth and if blossoms are cut away it will flower most of the summer.

S. prunifolia. (Plum-leaved Spirea.) (F.) 5-6 ft. White. April-May. This is an old-fashioned variety, flowers borne close to the slender, erect branches in the spring before foliage appears. The individual flowers resemble miniature roses and are usually borne in great profusion. The foliage is shiny dark green and in the fall turns bright red.

S. Reevesii. (F.) 4-5 ft. White. Mlay. This is one of the best of the Spirea group. White flowers, borne along the stem just as the foliage appears,

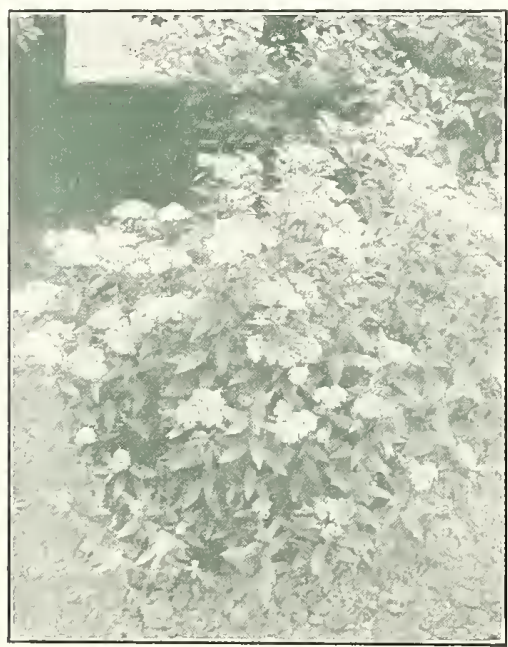

SPIREA ANTHONY WATERER 


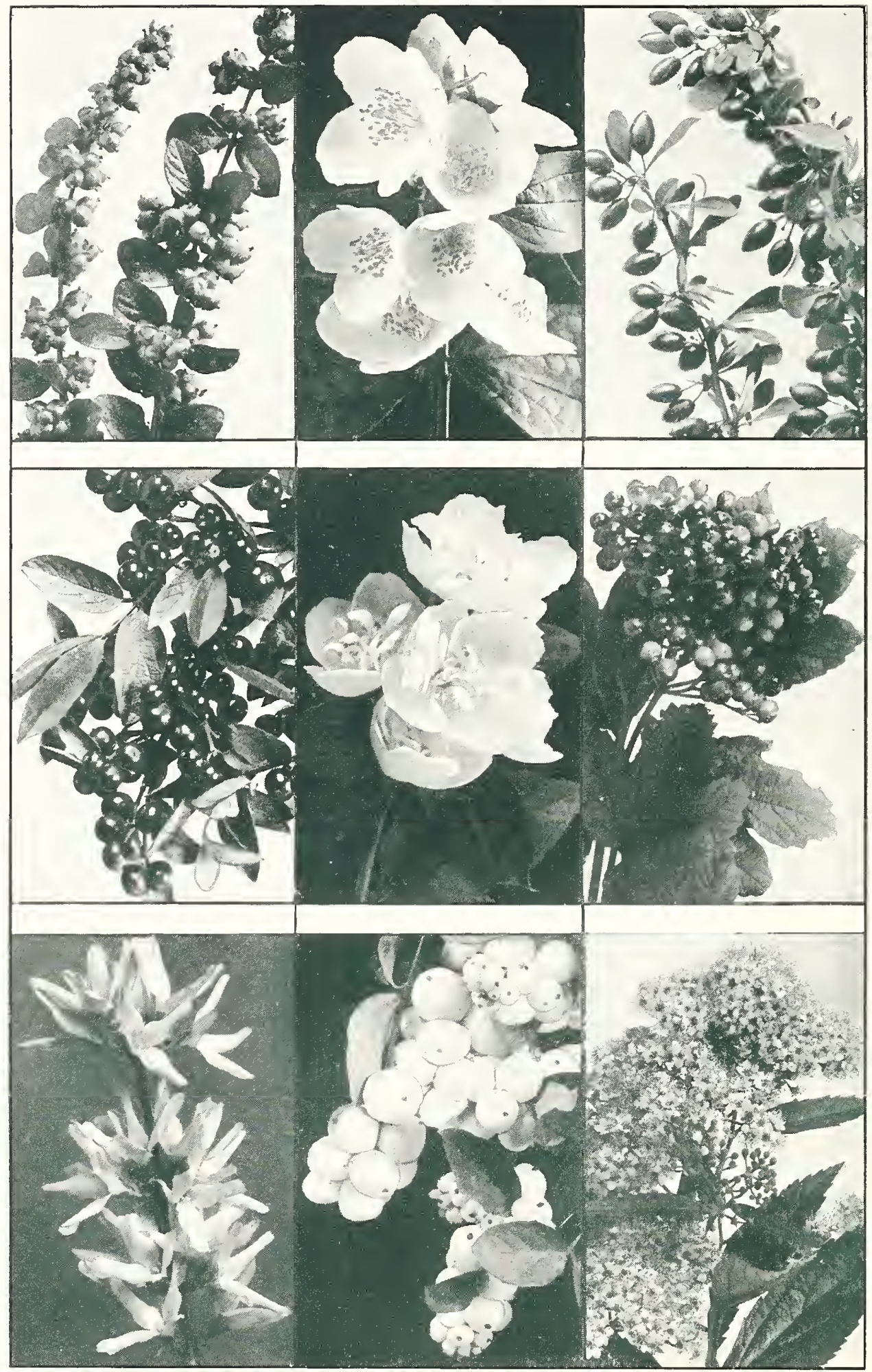

COR IL BERRY

HIGH BUSH CRANBERR FORSITHI.I FORTLNEI
SINGLE MOCK ORANGE DOUBLE MOCK ORANGE SNOWBERRY
JAPONICA

TET BEARD

ANTHONI WATERER SPIREA 
makes a most attractive bush wherever used. The foliage appears early and remains exceptionally late in the fall. In habit it is very graceful and can be used in foundations where plants of this height are desired.

S. Thunbergii (Snow Garland). (F.) $2 \mathrm{I} / 2-3 \mathrm{r} / 2$ ft. White. April. The extra early flowering species is the pride of the Southland. It is spreading in growth with arching, slender branches that are a perfect mass of minute flowers followed with exceptionally delicate green foliage. For edging purposes it has few equals and we recommend it highly.

S. Van Houtte (Bridal Bower or Bridal Wreath). (F.) 4-6 ft. White. May. This is the most useful of the hardy shrubs. It has grown so popular that we sell more of it than any other variety we grow. The flowers are in flat clusters usually an inch or more across produced on spreading, pendulent branches often drooping to the ground. In full bloom they are a mass of white and never fail to attract attention. The foliage is an attractive green which it retains late in the year. This variety can be used in any location for hedging, grouping and mass effect. There is nothing superior in the catalogue. When in doubt what to use, plant Spirea Van Houtte.

SUMAC. Staghorn. R. typhina. 10-12 ft. A large shrub or tree much used in landscape background work. Brilliant red foliage in the fall.

SYRINGA. See Mock Orange.

TAMARIX. Five-stamen. T. pentandra. Often called T. aestavalis. (F.) 6-7 ft. Pink. June. Shrubs with strong, but slender, delicate growth. Filmy, bluegray foliage similar to asparagus with carmen pink flowers in June and scattered blossoms the balance of the summer making it an unusually desirable shrub. Will grow in poor and dry soil.

TAMARIX. African. T. africana. 7-10 ft. Lavenderpink. April. This is the most vigorous of the Tamarix family. It has strong canes that bend gracefully as they lengthen. The blossoms appear on the stems before the foliage and are pleasing in mass planting. Sea green foliage and drooping habit make it very desirable for background or inter-planting in shrub borders.

WAYFARING TREE. Viburnum lantana. (F.) 10-12 ft. White. June. A large, vigorous shrub with soft, heavy lantana-like leaves and large clusters of white flowers in May, succeeded by red berries which turn black as they ripen.

WEIGELA. White or snow W. candida. (F.) $5-6 \mathrm{ft}$. White. May. Most vigorous of the Weigela variety. Flowers are large and quite showy. In exposed places the tops are sometimes injured in severe winters. Very rapid in growth and seems to thrive better in light soil.

WEIGELA. Red. W. Eva Rathke. (F.) 3r/2-4 ft. Crimson. June. Of smaller growth than the other Weigelas. It is decidedly spreading in character of growth and also attracts attention in bloom with its brilliantly colored flowers with white throats. It is especially showy and if given preference of light soil and slight shelter will prove an excellent variety.

WEIGELA rosea. (F.) 4-5 ft. Pink. May. The most popular Weigela sold to-day. Its delicate pink bell-shaped blossoms are borne in great profusion along great arching canes. There is also a scattering of blossom throughout the summer. The leaves are large and especially free of disease. This variety is the best of the group and is good for all uses where a shrub this height is needed.

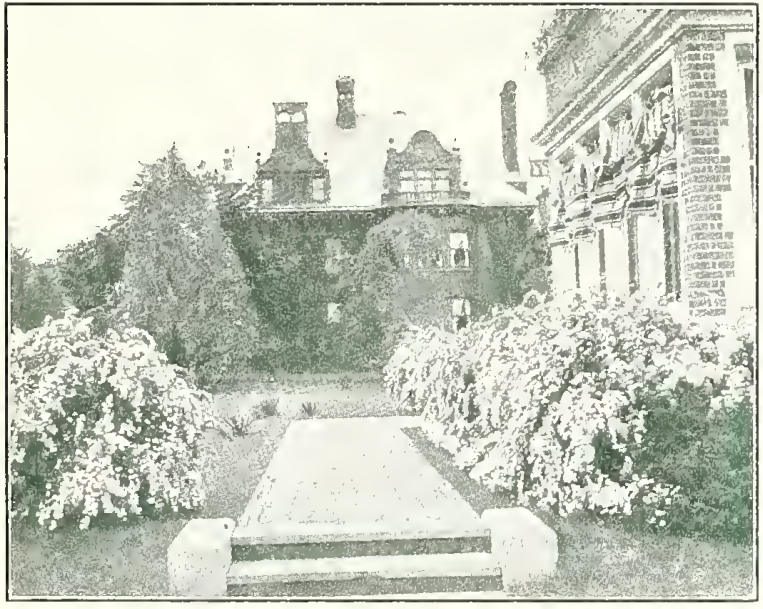

SPIREA VAN HOLTTE

WITCHHAZEL. Hamamelis virginiana. $8 \mathrm{ft}$. Yellow. November. An attractive shrub for producing naturalistic effects. Grows well in shade. Large in leaf and unusual because of period of blooming.

$$
* 4
$$

\section{HANCOCK DRY GOODS COMPANY., Inc.}

Roanoke, Va., January 8, 1925

To Whom It May Concern:

This is to certify that I have had considerable dealings at different intervals with the Hedge Lawn Nursery of this city and I wish to state that I think the people of this section should consider themselves quite fortunate in having a firm near them handling the lines necessary to beautify the grounds of their homes as they can do business with this firm without any hesitancy in any way so far as being dealt with in the fairest manner is concerned. In fact, it is a pleasure for me to do business with the above named firm knowing that I will be treated fairly in every respect.

Very respectfully,

W. R. Haxcock, President, Hancock Dry Goods Co., Inc.

\section{$* 4 *$ \\ JOHN M. OAKEY \\ (Incorporated) \\ FUNERAL DIRECTORS AND UNDERTAKERS}

Roanoke, Va., January 9, 1925

Hedge Lawn Nursery,

Roanoke, Virginia

Gentlemen :

The evergreens and shrubs which were furnished by you for my home in Raleigh Court were in every way satisfactory.

All the plants were in a healthy condition and your service in planting and arrangement have been very favorably commented upon by all who have observed them.

Yours very truly,

C. M. OAKEY. 


\section{HEDGES-BEAUTIFY AS THEY SERVE.}

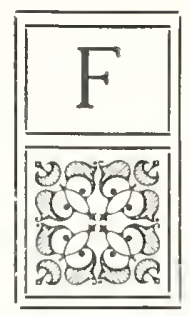

R boundary, screen or barrier there is nothing more pleasing than a hedge fence. With their bright green leaves they constantly bring a feeling inspired by the fresh foliage of spring. When formally trained or left to develop naturally their arched branches, colored foliage and bright berries are surely more pleasing than the mechanical effect obtained by the similar use of wood or metal. Most hedges are permanent and with the exception of occasional shearing they need little attention after being established.

\section{Planting}

The distances vary according to the conditions. Where an impenetrable hedge is wanted plant the Privets 6-10 inches, Japan Barberry 8-12 inches and the flowering shrubs 12-18 inches apart. Where height in wanted ratlier than thickness then double the distance. The size of stock purchased will make but little difference in planting distance. In planting, place as deeply or slightly deeper in the trench than they stood in the nursery row and firm well. Mosr hedges should be severely pruned at planting time. It reems at though you are cutting away good wood but to encourage growtl from the bottom it is necessary tw do this.

The after pruning should consist of clipping the young growth at regular intervals. There is no special time except it might be well to avoid late pruning in the fall as this encourages young growth that is frequently killed by severe weather.

\section{CALIFORNIA PRIVET}

Ligustrum ovalifolium. A semi-evergreen hedge with thick, shining, leathery leaves, that grows very rapidy, can be pruned into any formal effect and planted by every one needing a quick hedge without much expense and trouble. 1t blossoms in spring, the fragrant white flowers being noticeable for some listance. In planting it is a good iflea to cut away practically all the tops of the smaller plants in arcler to get a bushy hedge. We have quantities of this desirable variety.

\section{AMOOR RIVER PRIVET, SOUTH}

Ligustrum amurense. Semi - evergreen hedge that grows quickly. Occasionally it freezes to the crown in a severe winter, but always comes back with renewed vigor.

\section{REGEL'S PRIVET}

Ibota regelianum. This is the hardiest of the Privets we sell. It is semi-drooping in growth, making thick hedges from the ground line, growing $6-8 \mathrm{ft}$, if left unsheared. Thone wanting real permanency, or privacy, where a low hedge is wanted, plant this one.

\section{THUNBERG'S BARBERRY}

Berberis thunbergi. This Japanese shrub is being uned more and more as a hedge. Not as quick in growth as Privet, but absolutely hardy. Its small, glosiy leaves are out early in spring, succeeded by yellow flowers. The foliage turns a bright red in the fall and this is followed by red berries. It is a sraceful, drooping shrub, making an elegant variety for hiding foundation walls or planting in the corners by steps, etc. Also does well in shady places. Enpecially remarkable for its brilliant red herries, remaning fresh until spring, and for its dazzling fall coloring. Our heavier bushy plants will make immediate effect when planted.

\section{FRAGRAN'T BUSH HONEYSUCKLE}

Where high hedges are wanted there is nothing hetter. This hedge is semi-evergreen and will give you privacy the entire year. Of the many tallgrowing hedge plants now offered we consider this the best. It blossoms very early in the spring and is unusually fragrant. The glossy leaves immediately appear and these remain well into the winter.

\section{OTHER HEDGE PLANTS}

We offer Spireas, Altheas, Hydrangea, Abelias and other blooming plants in hedge sizes. Write for prices.

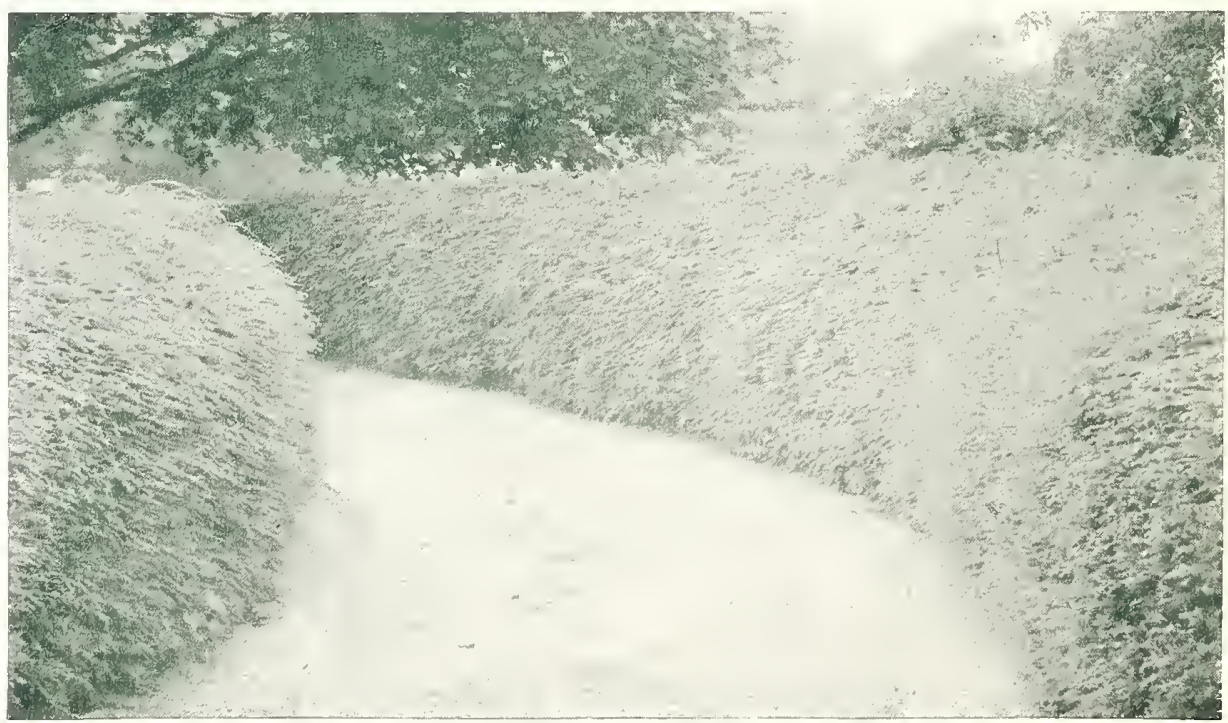

WE HAVE MANY VARIETIES OF HEDGE PLANTS IN VARIOUS SIZES 


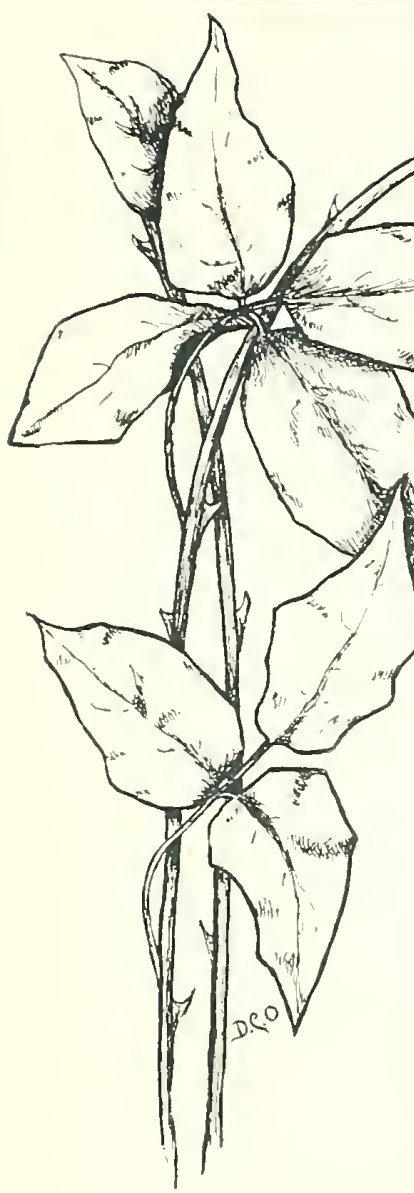

FTER YEARS of
breeding, experimenta-
tion and testing, rose
varieties have advanced many
steps beyond the garden of
our grand mothers, so
wonderful in June. Now we
may have a succession of
bloom all through the grow-
ing season, in colors and
shades to suit every fancy.
They can be used everywhere
a foliage plant or blossom is
wanted, or trained to ramble
over fence, trellis or arch, embankment, walls or abutments, or entwined about posts, trees or pillars.

\section{Suggestions for Rose Culture}

Plant only in a sunny position in soil free of all tree roots and protected, if possible, from severe weather.

\section{Soil}

Roses like fertile, well-drained soil and if one will prepare a bed especially well, he will be rewarded in wealth of bloom and vigor of plant. An ideal top-soil would be sod from a pasture mixed with well-rotted cow manure on clay sub-soil.

\section{Pruning}

In planting, prune them back to three or four good buds, as they will grow off much better. The everblooming roses should be shortened back each year about one half the previous season's growth. The ramblers may be pruned by taking out the older canes after they are through blooming, leaving only the younger canes, or by removing the flower spikes from the old canes. Our plants are own-root and field-grown and not the small pot roses usually offered.

Winter protection in the way of soil mounded up several inches about the plant, straw, manure, leaves or litter, especially about the tender varieties, repays in flowers the extra trouble.

\section{Enemies}

While healthy and vigorous plants are not especially susceptible to disease or pests, some pests will appear. For the leaf-eating insects, chafers, slugs and beetles, use arsenate of lead. For aphis or leaf hopper use kerosene emulsion or if diseases, leaf spot or mildew, use bordeaux mixture. Potassium sulphide, one ounce to three gallons of water, controls mildew better than anything else.

The list we offer contain the "cream" of the ones that do well here. The Hybrid Teas are the everblooming typen, a little tenderer but bloom over the entire season. Hybricl Perpetuals bloom profusely in June, then follow a scattering of blosonn until frost.

\section{WHITE ROSES}

Clothilde Soupert. A bedding rose of merit. Blooms exceptionally well all through the summer. Its small, white blossoms, with pink outer petals, make it unusually attractive.

Druschki-SNOW QUEEN or White American Beauty. (H.P.) This is a wonderful rose, in bud or full blossom. Owing to its vigorous habit of growth, it produces great masses of large, pure white flowers in June, and regularly during the summer. Perhaps the best white in existence to-day.

Sir Thomas Lipton. This is pure Rugosa rose, both in bloom and foliage and is, therefore, hardy everywhere. Flowers perfectly double and plant vigorous.

White Cochet. (H.T.) This is the best of its kind. The plant is healthy and will produce, in congenial surroundings, a great profusion of flowers. In bud or when full blown it is very fine. Color white with outer petals slightly tinged with pink. You make no mistake in planting it.

\section{SALMON PINK}

Captain Christy. (H.P.) (Lacharme, 1873.) Has foliage of rare beanty, dense and deep green in color. The delicate buds, together with the very large, full flowers of pale peach color, deepening

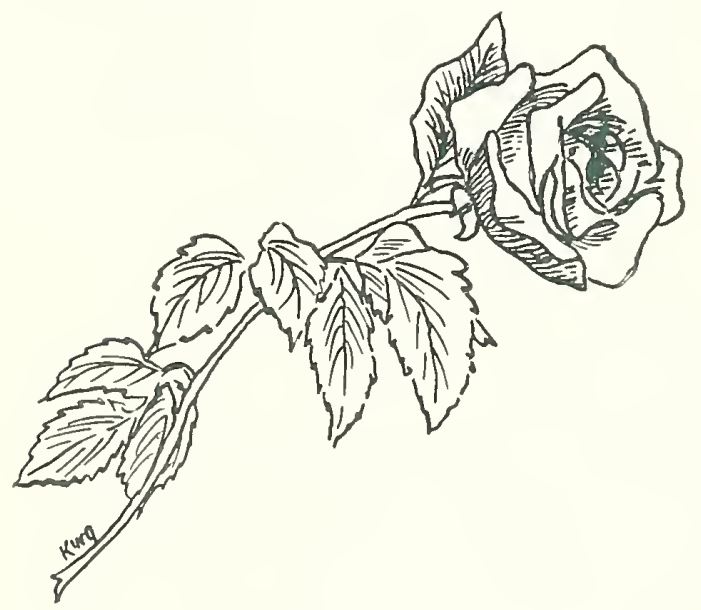

DR. VAN FLEET

towards the center, making it of striking appearance. Blooms almost the entire season.

Mrs. Aaron Ward. (H.T.) (Pernet-Ducher, 1907.) Center Indian-yellow with edge primrose. Medium size flowers, free and full.

Lady Hillingdon. (T.) (Lowe \& Shawyer, 1910.) Deep orange-yellow, good sized, long and pointed bud; excellent for cutting. 
Los Angeles. (Per.) (Howard \& Smith, 1916.) One of the finest Roses ever introduced. The growth is vigorous and produces a long-stemmed flower of a luminous flame-pink, toned with coral and shaded with translucent gold at the base of the petals. The buds are long and pointed.

Irish Fireflame. (H. T.) (A. Dickson \& Sons, 1914.) It makes beautiful buds that remain in shape a long time, having great substance. It comes with

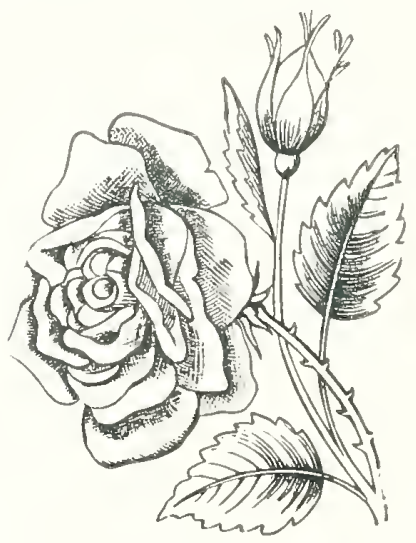

CAPTAIN CHRISTY

long stems. The color is old gold or copperyyellow, flamed with ruddy crimson. Certainly a most glorious Rose.

Ophelia Golden (Golden Ophelia). (H.T.) (B. R. Cant \& Sons, 1919.) Yellow in center, paling slightly at the outer petals. A seedling of Ophelia, possessing many of its characteristics.

\section{PINK ROSES}

Mme. Caroline Testout. (H.T.) (Pernet-Ducher, 1890.) Clear, bright, satiny pink. The Rose that helped make Portland, Oregon, famous.

Hermosa. This little bedding rose has won its way into the hearts of every rose lover. It is an everbloomer in every sense of the word, if the weak wood is removed and pruned annually. In color a most pleasing pink, blooming all over the bush, making a mass of blossom.

Mrs. B. R. Cant. (H. T.) This is the freest blooming rose we offer, especially is it true in late summer

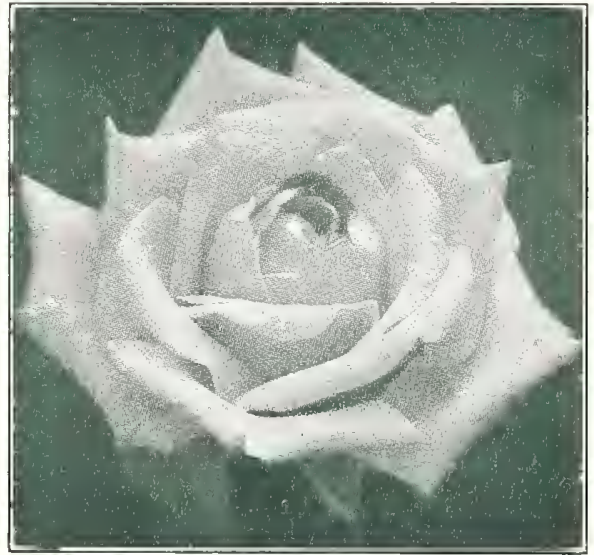

RADIANCE

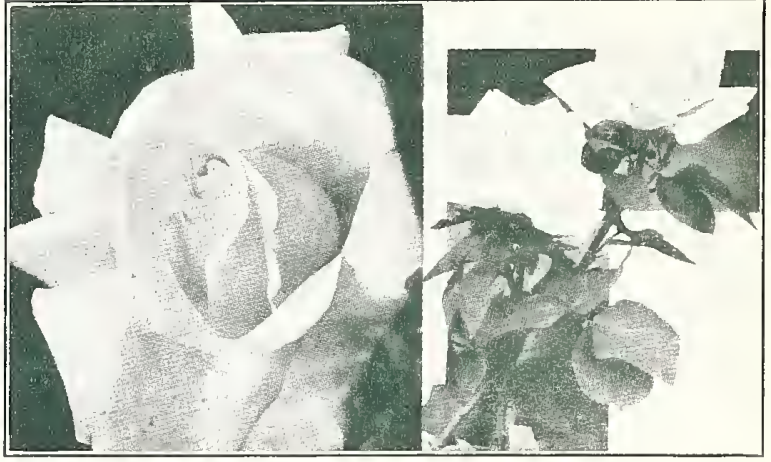

LOS ANGELES

FRAU KARL DRUSCHKI

and early fall. The bush is vigorous, free from disease. The pointed buds open into beautiful double flowers. A very dark pink fading into a most pleasing shade that everyone loves. We prize this variety highly and recommend it on its merits.

Paul Neyron. (H. P.) No doubt of its being tlie most popular hardy perpetual grown. Because of its vigor of bush and pleasing color, large size and comparative freedom from thorns there is an unprecedented demand for it always. It is clear rose pink, sometimes called pink American Beauty, which it resembles much in form and color.

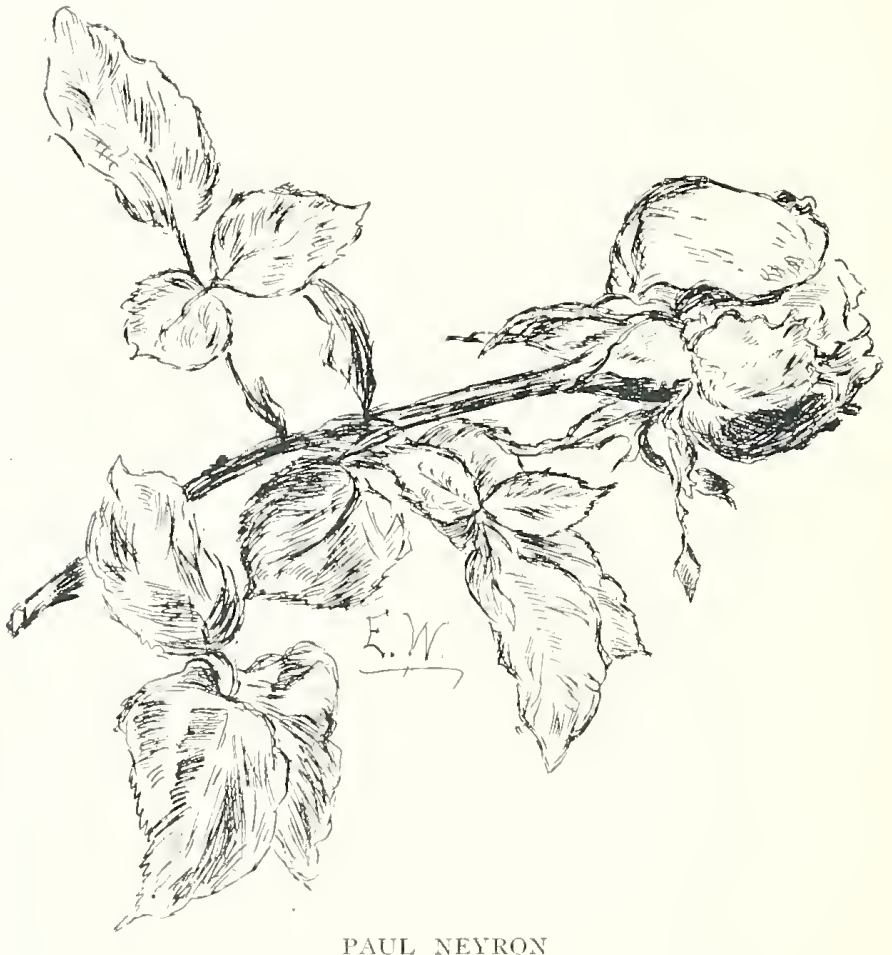

PAUL NEYRON

Pink Cochet. (H. P.) This we believe to be the best one of the pink roses to-day. Strong of bush and a great producer of exquisite buds and flowers. In color a deep pink, save outer petals which are silvery rose pink. Blossoms very double. Plant it, it won't disappoint.

Radiance. (H. T.) This is a brilliant rosy-carmine with decided opaline tints in open flower. 


\section{RED ROSES}

Gruss an Teplitz. One of the best garden Roses, giving many beautiful flowers over a long period. Gruss an Teplitz bushes are well covered with blooms from early June until frost kills the buds. Fevv varieties have such a profuse blooming habit. The flowers are crimson-scarlet, bright enough to attract the attention of the observer, but not vivid enough to throw other sorts into the background. Fine for mass-planting and hedges.

General Jacqueminot. (H.T.) Affectionately called "General Jack" and truly a veteran of many years. It is known and wanted by everyone and notwithstanding the many new varieties this grand, old, brilliant scarlet, crimson Rose finds a place in

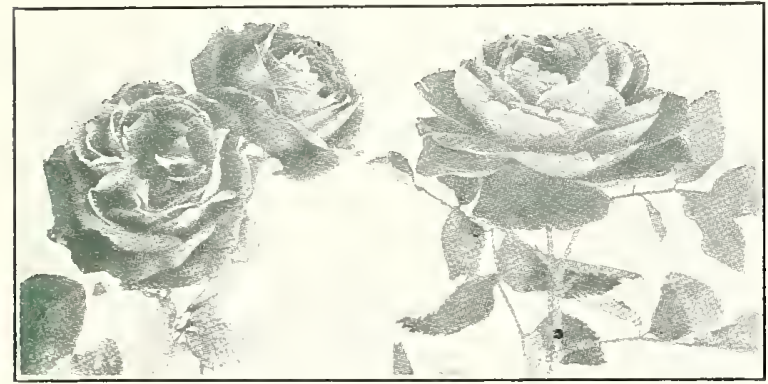

GENERAL JACQUEMINOT

GRUS AN TEPLITZ

every rose bed. Its rugged growth and free flowering ways have made it deservedly popular. Does well everywhere a Rose will grow.

Radiance Red. (H.T.) (Gude Bros., 1916.) The Washington Red Radiance. A glowing crimson sort of Radiance with all the magnificent qualities of the parent.

Captain Hayward. (H.P.) (Bennett, 1893.) Of largest size. Color glowing crimson, very bright and rich. About the best H. P. in the entire class.

\section{CLIMBING ROSES}

Alida Lovett. (H.W.) (Van Fleet, 1905.) Bright shell-pink, with shadings of rich sulphur at the base of petals. It resembles Dr. W. Van Fleet but is of a much darker color and the foliage is even more beautiful. Mildew proof.

Climbing Gruss an Teplitz. (H. T.) (Storrs \& Harrison, 1911.) A perfect sheet of crimson when in bloom. It's the same as the bush Teplitz.

Climbing Sunburst. (H.T.) (Stuart, Lowe \& Co., 1914.) Same as the well known bush. It's strong and vigorous and quite hardy. Recommend it to our customers every time.

Climbing American Beauty. This is a wonderful new rose resembling its namesake in character and size of bloom. In color it is a deep pink, not so dark as the bush form.

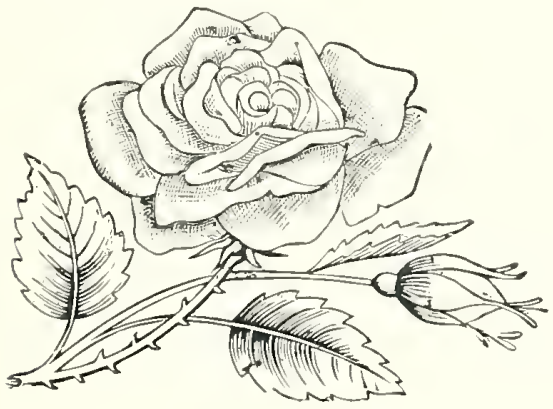

SUNBURST

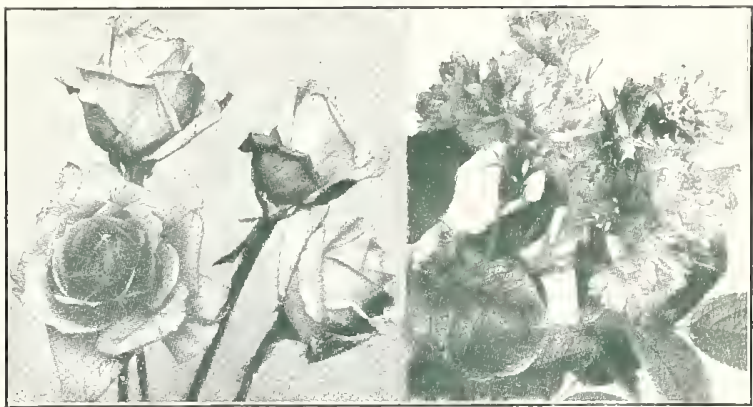

CAROLINE TEST OUT

F. J. GROOTENDORST

Dorothy Perkins. This variety is one of the most popular climbing roses to-day. It is a luxuriant grower and is easily trained over fence, veranda or trellis. A beautiful light pink, semi-fragrant, and blooming in large clusters.

Dr. W. Van Fleet. Blossoms extra large, resembling the tender Hybrid Tea Roses in shape and size. Its strong stems are tweive to eighteen inches long, making it valuable for cutting. In color, a delicate flesh pink changing when full blown to a Hesh white shade.

Baby Edith Cavell. (P.) (Jan Spek, 1917.) Brilliant scarlet, overlaid velvety crimson, with white eye; glistening, mildew-free foliage.

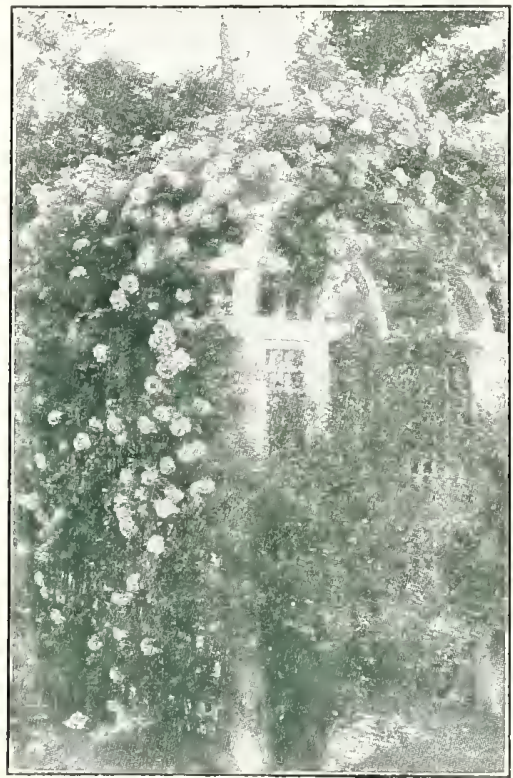

CLIMBING AMERICAN BEAUTY

F. J. Grootendorst. (P. R.) (De Goey, 1918.) This is a new type which might be called a Rugosa Baby Rambler, being a cross between Rugosa and the crimson Baby Rambler. Imagine a shrub-like Rugosa covered with trusses of crimson Baby Rambler Roses.

Paul's Scarlet. This new rose is the finest red climber introduced. Vivid scarlet, shaded crimson, semi-double, retains color till they fall. Vigorous grower.

Silver Moon. Another new rose that has made a name for itself. Flowers cup-shaped and largest of all the climbers. Semi-double and pure white with a cluster of beautiful yellow stamens in center. 


\section{HARDY PERENNIALS}

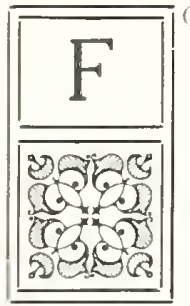

R permanent planting, for variance, for beauty of flower and pleasure, the perennial plants offer a field from which one may select in color, or in period of bloom, plants to suit the tastes of the most fastidious. Our list includes only the most desirable ones. There are hundreds of varieties and kinds, many are meritorious, but for the average bed, group or border, one will find the selection that follows suitable to ordinary purposes.

\section{Planting Suggestions}

Ordinarily perennials are set eighteen inches apart tor the larger-growing and fifteen inches for the dwarf plants. In planting a border, if one will mark his rows going each way so as to make squares the number ot plants is quickly ascertained, the arrangement as to height is easily arrived at and the grouping or planting made easy by alternating or varying a few inches from these rigid lines. Mulching, for winter protection, is necessary. Care must be taken not to smother the plants by covering the crowns.

May it be said that these plants thrive better in fertile ground and with plenty of moisture; should be well cultivated and kept free of weeds for best results.

Anchusa. We offer the deep blue shade of this ex cellent perennial. It grows four to five feet, and sometimes need staking. Blooms in May and the wiant stalks are a mass of pretty blue flowers. For the background of a hardy border this is indispensable where blue color is wanted. 4-6 feet.

Aquilegia-COLUMBINE. Blooming in late spring and through the early summer months, preferring slightly shaded positions, though it does well in the sun. The flowers are borne on slender stems and mostly long spurred. Coming in the many shades they do, prove very valuable in any border. 2-3 feet.

Beard Tongue or Penstemon. Has tall spikes of brilliant scarlet, tubular shaped and bearded Howers. I feet. Period of bloom, July and August.

Bleeding Heart or Dicentra. An old-time favorite Its arching stems bear drooping heart shaped Howers of white and old rose. Grows in shade. 1-2 feet. May and June.

Campanula - CANTERBURY BELL. A not he r garden favorite. Blossoms borne on long stems in many shades and colors. Partial shade and rich soil produce the better blostoms. This is a biennial, but hould be in every garden. May and June. $2^{\mathrm{T}}{ }_{2}-3$ feet.

Carnations. These are the hardy border Carnations. We offer these in mixed colors. The flowers are medium sized and have all the characteristics of the rarietie, grown under glass. 1-2 feet. Jun to September.

Chrysanthemums. These are hardy and most attractive in September and October. In planting these try to group them as some seasons it may be necessary to save from early frost by covering. Height, 2-3 feet. The flowers are very attractive. borne in large quantities. Colors-White, Pink, Red and Yellow.

CONE FLOWER. Rudbeckia purpurea. Purple red petals with cone-shaped center. Height, 3 feet. July to Augurt.
Coreopsis. A beautitul yellow flower, desirable for cutting or for border. After blooming, the seed may be cut away and a good secondary blossoming will follow all through the summer. Height, 2-3 feet. Graceful. June to August.

Delphinium, Light Blue, Belladonna. The praises of this variety have been sung by every lover of the hardy border. Light turquoise blue flowers are borne in spikes, the first coming in June. These may be cut away and young growth will start from the crown, producing blossom all summer. Height, 3-4 feet. Mulch lightly, as crown sometimes rots in winter.

Delphinium, Dark Blue. Bellosamum. This is an improved dark blue with all the other characteristics of the preceding. 3 feet. June to September.

Delphinium, English Hybrids. These are taller growing, being $4-5$ feet and in all shades of light and dark blue. June to September.

FOXGLOVE-Digitalis. This biennial is an old garden favorite. The flowers are borne on long stems (3-4 feet), and during their period of blossom are the most attractive thing in a border. These plants are not offered as to color, but are mixed seed from best plants. They are, ordinarily, very easy to grow, thriving in loose, rich soil. May and June.

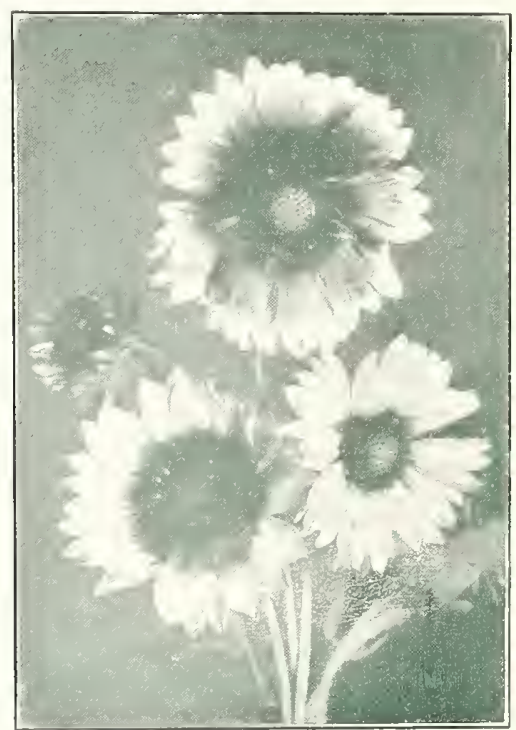

G.IILL.ARDI.

Gaillardia-BLANKET FLOWER. Will grow anywhere, bearing large quantities of yellow flowers flecked and marked with crimson and brown. Starting in June, there are blossoms all summer. One of the most desirable plants for the home garden and the flowers are valued for cutting. 2-3 feet.

Geum or Avens. A new border plant producing large dazzling scarlet Howers. 1-2 feet. May to July.

Helianthus-SUNFLOWER-Miss Mellish. A beautiful yellow, blooming in August and September, flowers being two inches across and on strong 
stems. The flowers are single and the foliage free from disease. Spreads quickly and produces tall stalks. 5-7 feet.

Hollyhocks. Everyone knows them-with their long spikes of multi-colored flowers, borne in profusion as they are, there is no wonder they are so largely used. Blooming in June and July, so absolutely hardy that they will take care of themselves.

Hibiscus-MALLOW MARVELS. Larger and more brilliant than the old forms. Plants frequently grow five feet and during July and August produce flowers eight and ten inches across, especially if given water. We can furnish in white, pink and red.

Eulalia japonica. 5-6 feet. A hardy grass of robust growth and light green leaves. Used largely for background or centers of beds

Eulalia gracillima. 3-4 feet. This is the most graceful of grasses and, therefore, most popular. For individual or mass planting it is unexcelled.

Eulalia variegata. Long, narrow leaves with prominent white stripe. Medium grower.

Eulalia pennisetum. Dwarf. 2-2I/2 feet. Very fine leaves and excellent for bordering.

Eulalia zebrina. Similar to japonica, being, as the name indicates, cross striped with white.

LILY, Hemerocallis, Day. These are the popular Lilies that thrive in any border. Like moist and semi-shaded location but will grow anywhere. Color, yellow. June and July. 2-3 feet.

LILY, Funkia, Plantain. Pure white flowers with large, showy leaves. Especially fine for shady spots. 1-2 feet. July and August.

Pachysandra-JAPANESE SPURGE. Fine evergreen ground cover for shady locations. Once established, makes a perfect mat.

\section{Phlox}

Nothing grows in the perennial class that is as satisfactory as the Hardy Phloxes. They are wonderful in their many shades, their profusion of bloom and general good character. Our list is not large but the very best varieties of their respective colors from a test row of many kinds. It is a good idea to break out the flowering spikes after they have finished blooming. Root-prune or transplant every few years.

(Sir Edward) Landseer. A brilliant, pleasing shade of salmon-red. Very striking.

(Frau G. Von) Lassburg. A late white, producing great spikes or trusses of pure white flowers. Fine.

(Miss) Lingard. Another white but blooms in April. Removing seed spikes a good second bloom is to be had. Best white known. Early.

Pantheon. Just as soft, pleasing shade of rose pink as could be had in a Phlox. Blooms in July and very fine

(Sir Richard) Wallace. Vigorous grower and pronounced the best of its season. White with violet center. Attractive.

Pinks. Hardy double variety of perennial Pinks, often called Florist's Pink. 1 foot. Blooms profusely in June.

Platycodon - JAPANESE BELLFLOWER. This comes in blue and white. Blossoming in July, the attractive flowers, often three inches across, come in succession for several weeks. Height $2 \mathrm{I} / 2-3$ feet.

POPPIES. These are Oriental Poppies, vivid shade of red, blooming with the peonies, and the joy and admiration of everyone. Plant a few of our divisions and have flowers the first season. 2-3 feet. We advise fall planting only.
Pyrethrum-PAINTED DAISY. One of the most desirable perennials blooming in May and Jume. Attractive. We list mixed shades. 2-3 feet.

Rudbeckia-GOLDEN GLOW. A yellow blooming perennial that has become popular in a very short time since being introduced. The flowers, in July and August, are like small Chrysanthemums borne on the terminals of 5-6 feet stalks. Very desirable.

Sedum, or STONECROP. Thick, cactus-like leaves that are attractive from early spring. producing Hat terminal clusters of pink flowers in August and September.

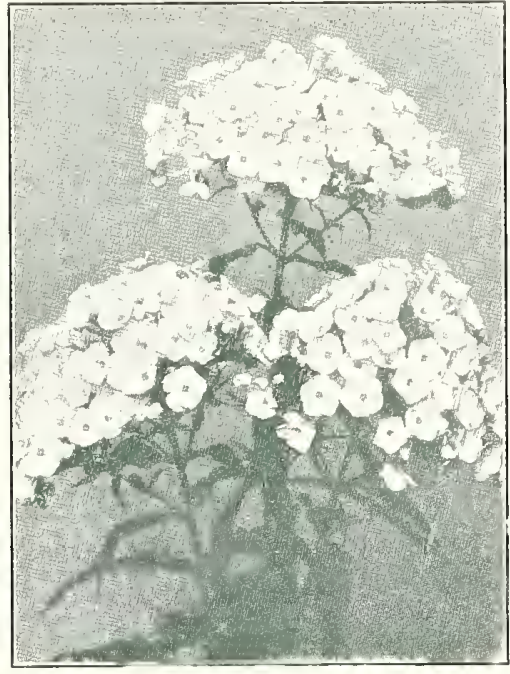

PERTNNTAL PHLOX

SHASTA DAISIES. Vigorous growing plants, height 21/2-3 feet, simply masses of wonderful daisy-like flowers borne on great stems. They are fine for cutting for the house or mass effect in the border. Plants from seed of improved Alaska type. June and August.

LATHYRUS. Sweet Pea, Perennial. This is a hardy vine, robust growing and fine foliage. Flowers in shades of pink, continuous blooming from June to frost.

SWEET WILLIAM. Another good old-fashioned plant, so well known that description is not necessary. Flowers in June and is a picture with its white, violet and crimson blossoms. No oldfashioned border is complete without their cheerful, sweet-smelling and showy flowers. 18-24 inches.

Newport Pinks. These are similar to the ordinary Sweet William save in color; are all light salmon pink.

Tritoma-RED HOT POKER. This blooms from July until frost time. The flower spikes are bright red cone-like heads that protrude above the drooping green leaves several feet. It is rather unusual and attractive. 2-3 feet.

\section{Iris}

There is a peculiar charm about the Iris that appeals irresistibly to those whose taste for the refined and delicately beautiful leads them to seek a closer acquaintance with it. Its irridescent coloring, fragile, orchid-like formation is often unnoticed by the careless observer. But those who only know the Iris as "flags" have never really examined "the rainbow flower," "messengers from the Queen of Heaven to mortals on earth." We want you to plant 
some of them and see that one investment mean years of beauty. They will last indefinitely when once established.

\section{GERMAN IRIS}

These are the old-fashioned Iris, and the varieties we offer are exceptionally meritorious, being selected for variety and distinct coloring.

Black Prince. Standards light lavender; falls lavender.

Florentina alba. Standards and falls white, tinged with yellow and blue.

King. Standards lemon yellow; falls satiny brown, edged sulphur.

Loreley. Falls slightly yellow, heavily veined purple; standards yellow.

Pallida Dalmatica. A tall variety. Lavender shading to blue.

Pauline. A striking lavender-violet variety.

Sherwin Wright. A golden yellow with practically no marking.

Spectabilis. The old-fashioned royal purple variety.

Queen of May. A soft rose-lilac, almost pink.

Walneri. Standards lavender; falls a purple-lilac.

We also have from trial rows in limited quantity:
Chester Hunt

Gagus

Hiawatha

Honorabalis

John DeWitt

\section{Jordan \\ Mary Garden \\ Mrs. H. Darwin \\ Mrs. H. Neubronner Quaker Lady}

\section{JAPAN IRIS}

This is the latest blooming of the Iris. Anyone not familiar with these has missed one of the glories of the garden. They bloom in June, being the largest, showient and contain varieties that for variance of colur and beauty are unsurpassed by any perennial. Prefers moist soil, but blooms exceedingly well on any type. We are limited in several varieties and will have to substitute if sold out when order is received. We list six varieties to color and letter as the names are difficult to pronounce. They are all delicately and variously veined and shaded, all being favorite sorts.

A. White.

B. Dark Purple. E. Mahogany.

C. Lavender.

\section{SIBERIAN IRIS}

Resembles the Japanese varieties in character of growth. lilooms earlier. Purple veined, gold in color.

\section{Peonies}

\section{THE GRAND OLD-FASHIONED FLOWERS}

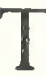

HERE is no doubt but that the Peony is the superior perennial. Those who now know the newer and better varieties or who have seen them in comparison with the older kinds readily admit that there is nothing quite surpassing them in beaty and charm. Of all the perennials they are the mut permanent. 'They are long lived as you, no doubt, recall those that were so long in your grandmother's garden. Their ease of culture, hardiness and freedom from disease and insect pests make them rightfully popular. Much has been written and said about the Peony and of all that has been printed or heard I have yet to hear an exaggeration.

\section{Planting}

It thrives best in deep, rich soil and a sunny exposure. It will grow in partial shade but usually proves a complete failure when planted near the roots of trees. Never plant roots of Peonies deep in the soil for they will grow but little and seldom bloom. We never cover the buds or eyes more than three inches as this is sufficient.

\section{About Fertilizing}

You have been previously advised to apply manure in the winter. This is not the best practice but to apply it during the summer or growing season. Well-rotted manure or compost will not injure even in the winter but fresh manure may do so. Bone meal, too, is a fine fertilizer.

Plant them along the walks, in the perennial border, in beds, in front of shrubs or anywhere and they surely will repay you for the space they occupy.

\section{WHITE PEONIES}

Baronesse Shroeder. A very delicate flesh pink, fading to white with suggestion of heliotrope and gold. Midseason.

Festiva Maxima. The grandest of the whites. Early. The flowers are extra large, color a pure white save carmine tipped petals.

Couronne d'O. A cream-colored white, compact blossom and very desirable. Late.

Duke of Wellington. A midseason white of unusual vigor, often having several blossoms to each stem.

Mad. de Verneville. Another very desirable white variety, free bloomer and should be in every collection. Early.

\section{RED PEONIES}

Francois Ortegat. A midseason to late variety, being very dark rose color with yellow stamens; flowers large on strong stems. Extra good.

Delachei. A late, deep, rich red, of unusual color. An old favorite and esteemed by everyone who knows it.

Felix Crousse. A midseason variety of the most pleasing velvety red color, fading to lighter shades as the blossom falls.

Officinalis rubra. Rich, dark crimson. This is the old-fashioned extra early red and still very scarce.

\section{PINK PEONIES}

Asa Gray. A soft, shell pink, mottled and veined rose. Midseason, and plant vigorous. Supply limited.

Alexandre Dumas. A strong midseason, free-growing pink of deep and pleasing color.

Edulis superba. Another deep rose of different season, valued for its fragrance and freedom with which it flowers. Early.

La Tulipe. Of late season, compact blossom, white, with streaks of red and pink on many petals. Resembles the tulip somewhat.

Livingstone. Late; clear pink. Very fine.

Marguerite Gerard. Another delicate pink, midseason, of great vigor and size.

LaPerle. Deep, lilac-white, blush center flecked carmine. Medium sized rose type and fragrant.

Mons Jules Elie. Large compact, lilac-rose with lighter pink base petals. Fragrant. Early to midseason.

Venus. Pale hydrangea pink, large, compact crown. Midseason. 


\title{
CLIMBING AND CLINGING VINES
}

\author{
LEND CHARM TO ANY HOME
}

\section{एकำ}

W TTH their variance in color, their beauty of cliage and blossom, their grace wherever used, these vines frequently provide the finishing tonches of any planting. Some adhere to the masonry, some must be trained through lattice or trellis and others, with their tendrils, will cling tenaciously.

\section{AMPELOPSIS}

A. Englemannii - I M P R O V E D V I R G I N I A CREEPER. Valuable for covering old fences, etc. Leaves red in fall.

A. Veitchii-BOSTON IVY. The beautiful selfclinging vine that is used to cover walls of stone or brick. Leaves form a dense sheet of green as they overlap each other; a little difficult to start, but when once established requires no further care. Foliage changes to a crimson-scarlet in the fall.

\section{CLEMATIS HYBRIDS}

These popular vines are known and planted everywhere for the profusion of beautiful, large flowers they produce. Not as hardy or healthy as C. paniculata, but when once established are worthy of all the extra care in getting them started.

C. Jackmanii. Large purple.

C. Andre. Large red.

C. Henryi. Large white.

C. paniculata. The small, white, sweet-scented varieties that are beautiful both in foliage and blossom.

Hedera helix-ENGLISH IVY. An excellent evergreen vine, with glossy green leaves, unexcelled for covering walls in shady or cool places. May be used for porch or window boxes for all year effect. When closely sheared makes a good edging for walks or borders, being hardy and evergreen.

\section{EUONYMUS-BITTERSWEET}

E. radicans. A slow growing vine that adheres to the masonry and remains deep green all winter.

E. radicans vegetus - EVERGREEN BITTERSWEET. Another evergreen clinging vine of more robust habit, perfectly hardy and especially valued because of the profusion of red berries that hang on for several weeks.

Bittersweet (Native) Celastrus scandens. This is the familiar native vine that is so unusually attractive of berry in the fall and early winter. Very vigorous and healthy.

\section{HONEYSUCKLE-LONICERA}

HONEYSUCKLE. Hall's. This is the popular evergreen Honeysuckle, used by everyone for screen, beauty and fragrance. Blooms continuously and easy to establish. It is also evergreen.

HONEYSUCKLE. Coral. Flowers bright scarlet, little fragrance. Strong grower and hardy.

KUDZU VINE. Pueraria Thunbergiana. We have so many calls for a very rapid growing, twining vine to cover unsightly objects, for quick effect where other vines are too slow, that we list this vine. It belongs to the pea family, has insignificant flowers, but the foliage is very large, of attractive green color, and specimens have frequently grown thirty feet in a season after established.

TRUMPET VINE. Radicans. Bignonia. A robust, woody vine, twining tightly with numerous tendrils along its stems. Leaves are dark green. Very desirable for covering summer houses, arbors, trees or rustic bridges. Scarlet flowers.

WISTARIA. A rampant, clinging vine that has the robust vigor of a wild grape and matchless beauty of a rare exotic. Colors both white and purple.
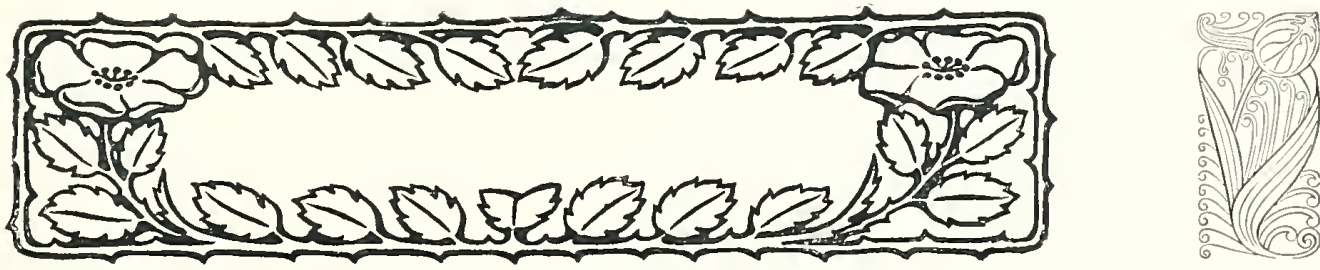


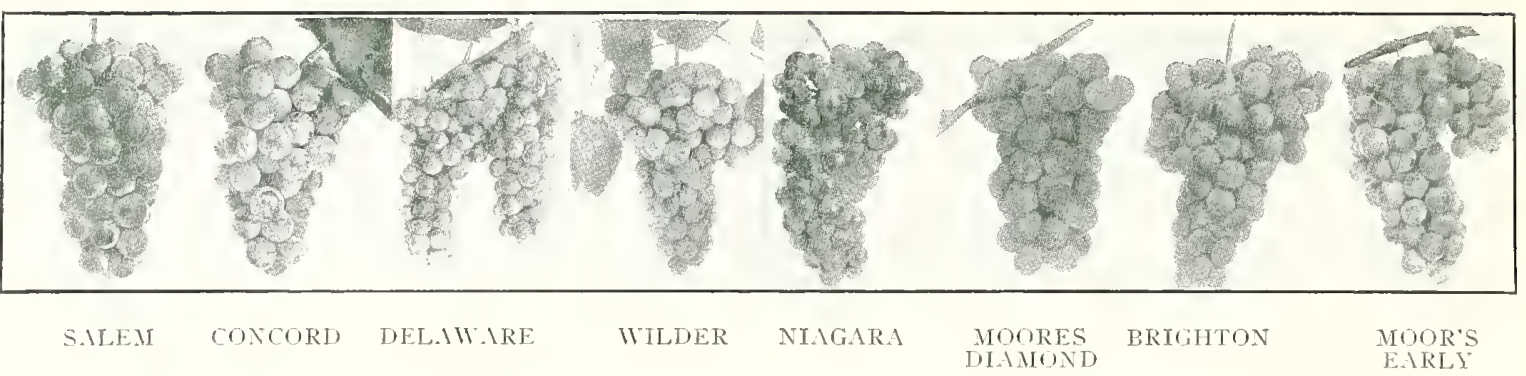

\section{HARDY FRUITS}

FOR THE ORCHARD AND HOME GARDEN

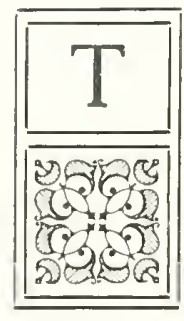

IS has been for years a most important feature of our nursery. A long experience in this section places us in a particularly advantageous position to suggest what to plant. Our catalogue of varieties shows those substantial and reliable sorts tried, tested and found satisfactory. Thousands of orchards are found to-day to bear this testimony and annually more are being planted. Distribution to the consumer has proven the greatest cost to the grower. In every section, on every farm, there is a suitable location for an orchard. These spots, now unprofitable, can be made to yield large returns. Quantity and quality will be the result of a few years of good, and not necenarily expert, attention. Rapid maturity and great harvest follow proper cultural methods.

Some of the common reasons for failure are: Unsatisfactory location, impoverished soil, unprepared areas, unsuited or too many varieties, unhealthy trees, poor planting, failure to prune at planting time, inability to mulch or cultivate as needed and the omitting of control methods for diseare and insects.

\section{PLANNING THE ORCHARD}

Two types of orchard are planted, commercial and home. The requisites of the former we will not mention here, except to say that we have too few. The planter is usually familiar with his conditions and at any time we will cheerfully give any advice that we can. The home orchard should be planted with an idea of a succession of fruit. An ideal selection as to season would be, fifteen per cent. summer, twenty-five per cent. fall and sixty per cent. winter varieties, when applied to apples. Peach varieties that mature in midseason and cherries of the earlier and sour types are suggested to predominate in a home orchard. The other fruits should be selected to meet individual requirements. Choose standard varieties or, if not familiar with the names, we will assist you. Then make a map of your orchard, so failures can be correctly replanted. Start nearest the home with the summer varieties. follow in succession with the fall and then plant the late maturing, as these should not contain many varieties but rather more trees of fewer sorts. The reason is obvious as picking, sorting, marketing and storing is made easier and more profitable.

For economy of space "the filler system" is frequently advisable, i.e., those trees that mature quickly can be planted between the permanent ones, the idea being to remove them when they have spent themselves or are crowding those of longer life. Peaches, especially, are recommended though plums and cherries may be used.

\section{Location}

Select a site for your orchard on high ground, so as to escape the frequent late frosts that prove injurious in the low lands. Soil preparation in the way of crop rotation and added fertility prove good investments. If you have choice of exposure, a northern or western slope is preferred. Soil not robbed of its fertility, properly tilled and in a physical condition to receive a grain crop will produce much better results than when trees are set in impoverished fields, barren wastes, planted in "post holes," no further attention given.

\section{GRAPES \\ The Universal Fruit}

$\mathrm{T}$ HIS ancient fruit is at home on any character of soil and there is not a place that should be without it. Whether in the vineyard or arbors, backyards, or trained on fences, porches or buildings, the grape bears with astonishing regularity. The secret of successful growing lies in proper pruning. The annual growth should be cut back to three or four buds each season, removing entirely the weak ones. As the vines produce better on the younger wood, consistent renewing from the bottom by encouraging new shoots every few years is recommended.

At planting time shorten the roots to $14-16$ inches and the tops to two or three joints and lay in trenches eight inches deep, with only the buds showing. By placing the roots all in one direction, stakes or posts may be renewed at any time without damage to the roots. Prune back the first season's growth, and the second summer train but two vigorous canes to stakes. At the end of the growing season shorten these to 3 to 4 feet, depending on the vigor of the plant, training off laterals to cover your wires or buildings from these.

\section{BLACK GRAPES}

Concord. This is, without doubt, the best general purpose grape grown. Its planting, perhaps, equals all the other varieties combined. Berry large. Bunches shouldered and compact.

Worden. A seedling of Concord, of better quality. Ripens ten days earlier. Bunch and berry large. compact. Not quite so hardy or long-lived; however, it should be planted in every collection. 


\section{WHITE GRAPES}

Niagara. The best white grape; bunch and berry large, meaty and juicy; flavor perfect. Weil known.

\section{RED GRAPES}

Brighton. Large, compact, shouldered bunch, with medium to large berry; juicy, sweet. Unsurpassed for table.

Catawba. Standard late red grape that has lost none of its popularity. Season and quality make it indispensable.

Delaware. A well known red grape. Bunch and berry small, compact. Flavor unsurpassed. Not a strong grower; must be given good, rich soil.

Lutie. An early grape of good size. Its popularity makes the vines scarce. Best, extra large.

\section{APPLES}

\section{Yield Profitable Returns}

$\mathrm{O}$ IVING to its adaptability to various soil conditions, its hardiness, productiveness and commercial value, we must consider the apple the most important of our tree fruits. Planted only in well-drained soil, with proper care taken in the selection of varieties, one may expect fruit from early summer throughout the winter months. An acre or so devoted to apples, properly planted and with ordinary attention to pruning and cultivation, will yield very satisfactory returns. Our list has been further reduced to only the most dependable sorts, and those listed below may be planted with confidence. As the trees develop, the trimming out of the cross and crowded branches is all the pruning required.

\section{EARLY APPLES}

Early Harvest. Pale yellow, sub-acid, regular bearer and is the nost popular of the old general purpose varieties.

Early Transparent. Very early bearer, productive; valuable for either home or market. Blights on rich soil, however. Waxy yellow, tart, excellent.

Maiden's Blush. A grand old favorite. Waxy yellow, pleasing red blush. Ripens over a long period, making it valuable for home orchards.

\section{FALL APPLES}

Grimes Golden. No orchard complete without it. Yellow, best quality and productive. For home or market for this season there is nothing better.

Northern Spy. Large striped. Crisp, juicy, aromatic. Excellent quality. Long coming into bearing.

Stark. An apple overlooked by many. Color oreenishred, unattractive for market, but for productiveness, regularity, vigorous growth, etc, should be in every farmer's orchard.

Wealthy. Large, shaded to dark red, quality good, tender and productive. Early to bear and exceed ingly satisfactory.

\section{WINTER APPLES}

Baldwin. Red, large, fine quality, tree vigorous. The commercial apple of the east.

Delicious. Red, large and uniform in size, distinct because of five lobes on blossom end. Variety new, very popular and no orchard should be without it. Quality uncxcelled. A very early and heavy bearer, good for market and home.

Black Twig. A seedling of Winesap, larger, splashed with red, sub-acid and very productive. We call especially recommend this for Virginia. Valuable for home or market. Plant it.

Jonathan. An early bearing variety, red, medium size and quality very good. Tree never large but productive.

Stayman Winesap. Dark, rich red, indistinctly striped; larger than old Winesap. Tree productive and a drought resister.

Winesap. Medium size, dark red, productive variety. excellent quality, crisp and juicy; sub-acid. The most extensively grown, the most abundant bearer, with more good qualities in its favor than any. thing we have to offer for Virginia.

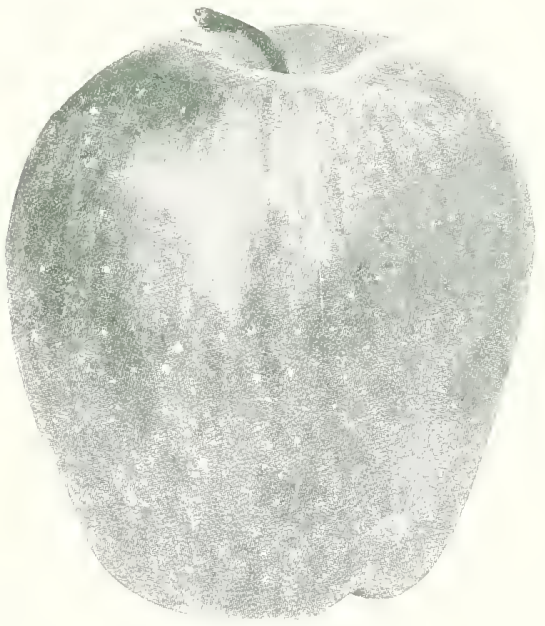

DELICIOUS APPLE

Winter Banana. With us really a fall apple ripening in September and hould be used before Christmas. Of unustially good quality. Yellow with attractive blush.

Ben Davis. Striped red, large and attractive. Surest bearer, healthy tree, vigorous and should be planted as a "catch" in every orchard. Greatest fault, lacks quality.

York Imperial. A late keeping commercial variety, shaded red on yellowish skin, flesh firm and tree healthy. Regular and heavy bearer. Plant for profit or for home.

\section{CRAB APPLES}

Hyslop. Large, dark. Tree vigorous and productive. Whitney. This is a really edible crab; late, and good for jelly or use from hand.

\section{PEARS}

\section{The Delightful Eating Fruit}

$\mathrm{T}$ HE Pear thrives in a rich, deep soil and when given good attention will yield very early. The quality of the European (E) variety is usually very ligh while the Japanese (J) varieties are usually more productive. The quality of the fruit, however, may be increased by picking before it is ripe and spreading in thin layers on a floor until they become soft. The fruit left on the trees to mature usually lacks the properties of those that are 
house ripened. The greatest enemy of the pear is the Blight and from present indications will eradicate this fruit until some successful control method is discovered. The disease unually starts at the ends and these branches wither and die. Cutting beyond the black mark, burning the wood and disinfecting the pruning tools is suggested. Spraying helps but does not control the dinease.

At planting time prune to three to five well developed branches distributed evenly about the main stem. Shorten these to six or eight muches.

Bartlett (E). August 15th. This is, no doubt, the favorite eating pear offered to-day. It is large, beautiful yellow with soft blush. In quality it has no equal. The tree bears quite young and on account of its popularity everywhere it is the most sought after of the European pears.

Clapp's Favorite (E). Angust 1st. This is a seedling of Bartlett and earlier ripenmg. It is lemon yellow in color with brown dots. In quality it is almost the equal of its parent. Ripens in early August.

Kieffer (J). September 10th-15th. This to-day is the most popular pear for our section. On account of its productiveness and freedom from disease it stands out pre-eminently. The fruit is large, golden yellow sometmes tinted red on the sun ex-

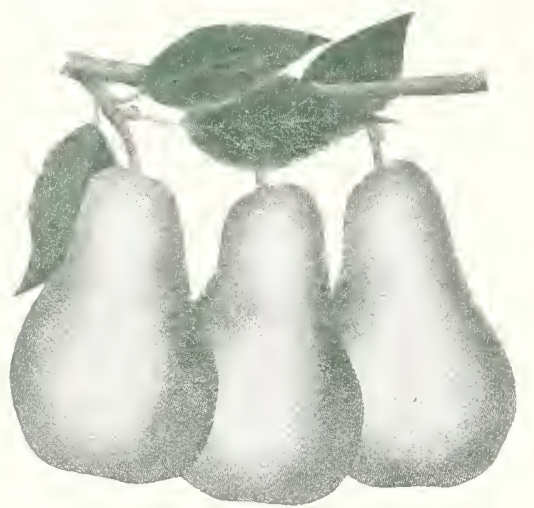

BARTLETT PEIRS

posed side. The flesh is very firm, crisp and juicy, and for canning purposes it is especially prized. From the tree it is not good to eat and to properly ripen, gather carefully and place in a warm place of even temperature. The quality improves and it is then desirable. For keeping longer, pack in shallow trays or wrap the fruit in paper and store in a room free from frost. It can be frequently kept until Christmas in this manner.

Seckel (E). September 15th. This small, high-quality, yellowish-brown pear is one of the most popular of the September fruits. Of melting, juicy and sugary quality (frequently called the little sugar pear) makes it one of the most popular varieties. The tree is of slow growth.

\section{THE PLUM}

\section{For Market and Home Use}

$\mathrm{T}$ HE Plum demands a rich soil and additional fertility given after a few years proves beneficial. The trees usually are planted about twenty-five feet apart and can be used as a filler in an orchard between permanent trees. They thrive especially well in back yards, gardens and in chicken runs. For home consumption the fruit should be allowed to ripen on the trees but for shipping they should be gathered a few days earlier. Some varieties always over-bear and thinning slould be done to increase the size of the fruit. The two enemies are curculio and rot. Both can be controlled by proper spraying and cultural methods. See spraying calendar or instructions. As the trees bear soon and are productive more should be used each year. There are three classes; the European (E) are better quality; the American (A) are superior for liardiness; and the Japanese $(J)$ bear earlier than any.

Pruming at planting time should consist of removing one-half to two-thirds of the length of all the side branches, leaving four to seven evenly distributed around the body of each tree.

Abundance $(J)$. July. One of the best and hardiest of the Japanese varieties. Fruit is large, oval and in color amber changing to cherry. The quality is very good and the tree is hardy. One of the best.

Burbank (J). Late July. A later, more vigorous variety than the preceding. In color, violet to light purple with occasional shades of yellow. Fruit is large, flesh yellow and of excellent quality. For either canning or marketing this is the most popular sort. We believe it to be the hardiest and most prolific of the Japanese varieties.

Damson (E). This variety has been a standard for years and is really too well known to describe Trees are upright in character of growth and usually bear great crops when given congenial soil. Succeeds everywhere plums will grow.

Green Gage (E). Another old variety that has been ontstanding for a number of years. It ripens in mid-August and its medium-sized, yellow-green, ligh-qualitied fruit makes it a standard of excellence by which the others are judged. The tree is a moderate grower but healthy.

Red June (J). July. A typical Japanese in character of growth, productiveness and quality of fruit. Color red; flesh yellow; semi-cling stone and of good quality.

Yellow Egg. Early August. A large early plum of pure yellow color. Of extra quality and tree a great bearer.

Wild Goose (A). This variety has been a standard favorite for many years. In vigor and productiveness it has no equal in the plim family. Is practically free from disease and if given good soil will well repay for the space it occupies. It annually produces a great crop of large, red plums of fair to good quality. A most valuable variety for home or market.

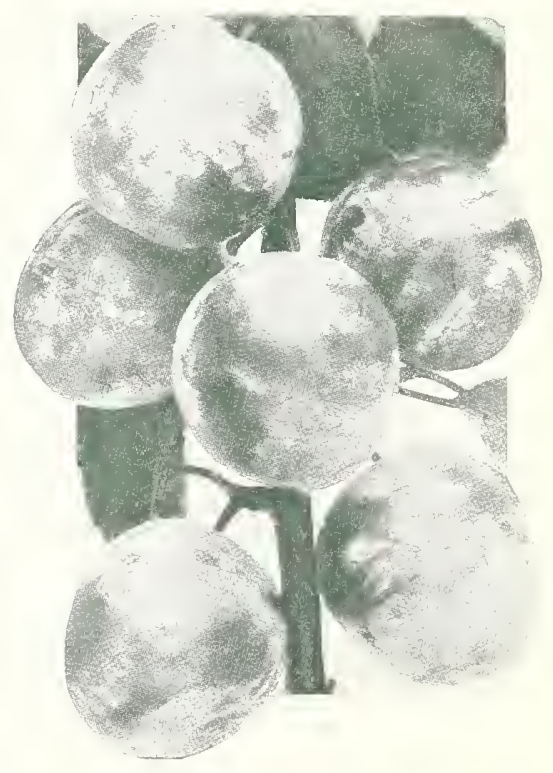

SHROPSHIRE DAMSON 


\section{PEACHES}

\section{Are Profitable and Popular}

L IGHT and well-drained soils, preferably sandy loams, seem to produce the best peaches. The tree is quick to mature, bearing heavily at an early age, and its comparative freedom from disease makes it deservedly popular. The annual pruning should consist of shortening in the terminal growth to maintain a round and compact head. When the crop is killed by severe winters as the one of 1918, "dehorning" or severe cutting in of branches is suggested. The tree bears its fruit on young wood.

The principal enemy of the tree is the "Peach Borer" that burrows under the bark below the ground line. Turning back the soil, scraping with a knife or prodding the runs with a wire is the surest remedy. Boiling water poured about the trees will also kill the borer.

In planting, prune severely. Cut away all the side branches to inch stubs and shorten back the leaders to form a balanced, low head.

\section{EARLY RIPENING}

Mayflower. (Free.) Red all over, fine and good. Earliest peach known. June 25th. Extra hardy.

Red Bird. (Cling.) A creamy white peach almost covered with red. Large, hardy and good. An extra early cling. July 1st-5th.

Greensboro. (Free.) The very best extra early commercial sort. Hardy and productive, fruit large and tree healthy. Color, white with crimson cheek. July 1 st.

\section{SECOND RIPENING}

Belle Georgia. (Free.) White with decided blush; excellent quality; heavy and regular bearer. In this variety we have the best white-fleshed peach for home or market. August 5th.

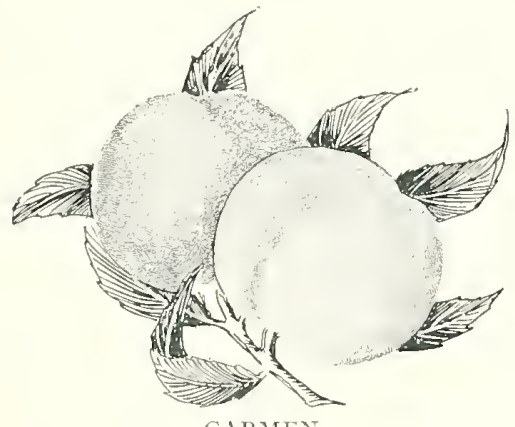

CARMEN

Carmen. (Free.) White with red blush. Carmen is extra hardy, bears every year and when it fails all else fails, too. Tree a robust grower and produces heavily. Next to Elberta, Carmen should be considered. We are partial to it. July 20th.

Early Elberta. (Free.) Well named, being a clear yellow with blush, finer grained and sweeter. Tree a strong grower, with a tendency to thin itself, carrying moderate loads of fruit. August 10th.

Champion. (Free.) White fleshed, with attractive red cheek, juicy, good quality and dependable. August ripening.

Elberta. (Free.) Beautiful yellow, large and shaded with deep red. Elberta has been the peach for years and is just as good to-day. The fact that more than eighty per cent. of commercial plantings are of this variety speaks well enough for it. August 15 th.
J. H. Hale. (Free.) Yellow, almost covered with red; more highly colored than Elberta: flesh firm, melting and of best quality. Ripens August 10th-15th.

\section{LATE RIPENING}

Heath. (Cling.) White, tinged next to sun. A large, firm, juicy peach of most pleaning flavor. Well known. October 1st.

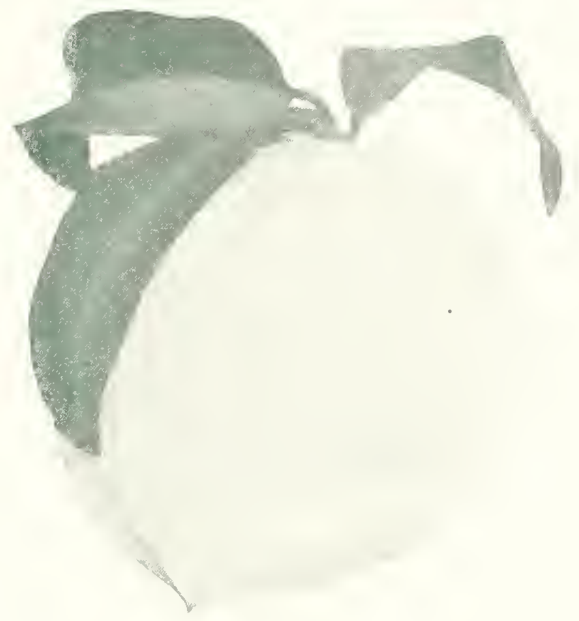

ELBERT A

Krummell. (Fiee.) Golden yellow, blushed red and carmine. Large, round, melting, sub-acid, good. Another new peach that is fast gaining in popularity. September 20th-25th.

\section{THE CHERRY}

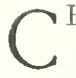

HERRIES succeed only in the drier soils, preferring types that are porous or stony to the low and heavy kinds required by other fruit trees. They do especially well in our section and though a little hard to establish should be planted in every orchard. We find our sour and sub-acid group more productive of fruit. They do not make trees quite as large nor as shapely as the sweets but they are quick to bear and usually yield extra heavy crops of fruit. They are much more dependable and for this reason we recommend their use. The sweet or Hearts make vigorous trees valuable for planting in back yards for shade but are not constant producers.

Pruning of the bearing trees is seldom necessary, save sawing broken or mutilated branches. Grouping the trees, especially the sweet varieties, for pollination purposes is suggested as they are sometimes barren when planted by themselves.

At planting time shorten in the branches about halfway, leaving four to seven to a tree and be very sure to tread the soil firmly about the roots. We have more complaints of cherries failing than all the rest of the fruit varieties.

Early Richmond. This old standard cherry has been the favorite for a number of years. In quality it is tart and very valuable for canning purposes. It yields nearly every year and reddens the tree with its wonderful crop. It succeeds everywhere cherries will grow and as it is the earliest in season of bearing it is very popular.

Late Duke. This is a sub-acid variety of a large, light red fruit, rich and tender in quality. The tree is decidedly upright in character of growth, resembling the sweet in this respect but decidedly hardier. 
May Duke. This ripens a little earlier than the preceding variety and, while not quite so vigorous in tree, the fruit is slightly superior. It is an old variety and has been tested and found worthy of a place in all catalogues.

Montmorency. This is gradually supplanting the Early Richmond principally because of its size. It resembles Richmond very closely except for being a little later the descriptions are practically the sime. This variety is not quite as acid as others of its group and when ripe is good to eat from hand. The tree is hardy, blooming late, and will make a crop frequently when the sweet varicties fail.

\section{HEARTS AND BIGGAREAUS}

Black Tartarian. This old-fashioned variety is to-day perlaps the most popular of the sweet varieties. The fruit is large, black and heart-shaped. In quality it is rich. The tree is vigorous and where one has suitable soil this one should not be overlooked.

Governor Wood. This is anotler variety that has been catalogued for a number of years and to date we find few that are superior to it in quality or productiveness. It is a pale yellow with blush; fruit medium sized and flesh soft and of good quality, making it a most valuable table cherry.

Napoleon. This and Yellow Spanish are very sinilar. lt, however, is a prince among its kind. The tree is more erect and productive of fruit. As a commercial sort it is planted in large acreage and for home use we consider it one of the very best of the sweet cherries.

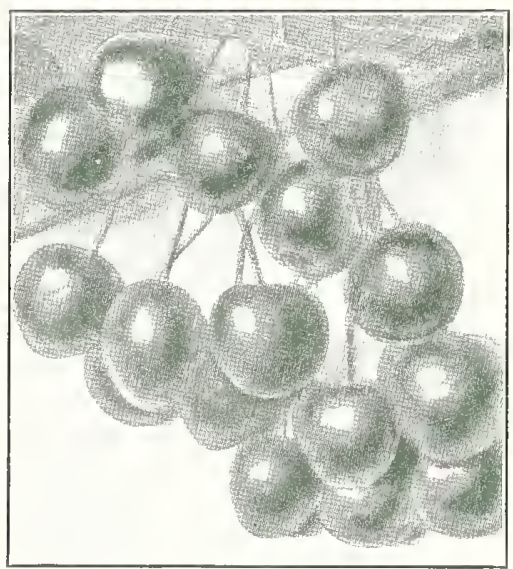

Yellow Spanish. This is a later variety than any of the preceding. Its large, yellow, firm and highqualitied fruit has made it exceedingly popular around the whole world. It is not quite as tender as some of the preceding and its fruit can be adapted to a multitude of uses. Not planted as it should be.

\section{THE QUINCE}

The Quince. Luxuriates in good, deep ground and on such will quickly yield an abundance of fruit just the best to preserve or for jelly. We have tried all the standard kinds, but the Orange has been by far the best for us.

\section{STRAWBERRIES}

\section{Always Productive-Always In Demand}

W E nlake the growing of strawberry plants a specialty and as they are planted in the spring only, we issue at that time an annual catalogue, devoted principally to the description of varieties and complete cultural directions. The shallow root of the strawberry does not permit planting in the fall, as the alternate freezing and thawing or ex-

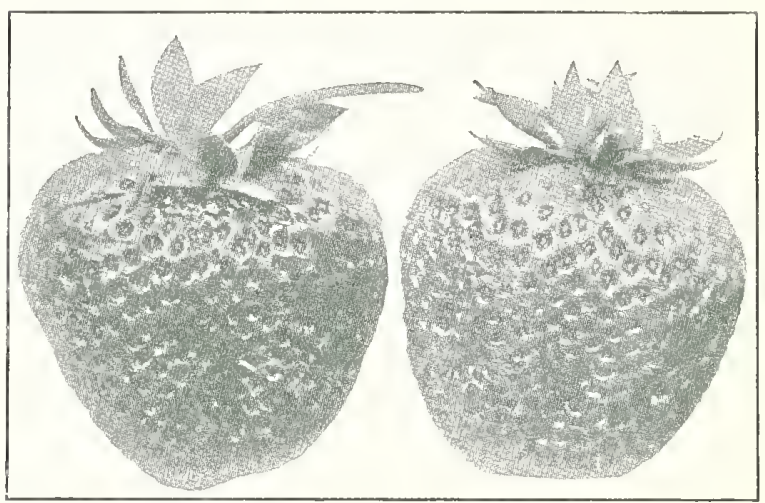

AROMA

pansion and settling of the surface soils throughout our falls, winters and early springs will expose the roots and cause the loss of the plants.

Aroma. (Per.) One of the most popular late market varieties. A good plant and a good bearer of large, handsome fruit; bright red in color, uniform roundish heart-shape; firm and of good quality. Somewhat resembles Gandy in appearance. A choice variety and reliable.

Price, 50c per doz; $\$ 1.00$ per $100 ; \$ 8.00$ per 1,000 .

Campbell's Early. One of the earliest varieties grown. The plant is a very robust grower, strong and healthy; one of the best of the early fertilizers, as it blossoms early and late.

\section{PLANTING THE ORCHARD}

Read carefully "Planting Instructions" on Page 3.

Do not expect a tree to grow unless you can give it some subsequent attention after planting. Cultivate an orchard or tree just as you would a garden. It is a good practice to intercrop, that is, between the rows of trees, low-growing vegetables and berries may be planted without losing the use of the land and at the same time keeping the trees growing vigorously. Green manure crops, grain and legumes may be plowed in to further enrich the soil, care being taken not to injure the bodies of the trees when so doing.

\section{Spraying}

This is not difficult but rather easy after understood. First: Figure out what you are spraying for, disease or insects, so it can be done intelligently. Second: Do a thorough job for time, material and results are wasted by carelessness of application.

Get a good sprayer (and there are lots of them) of a type suited to your needs. When through using. wash and rinse thoroughly, drain ont the hose and pipes and store out of the weather, for many parts 
are indestructible and will last for years. A spraying calenclar, with some instructions, bulletins and further information, may be had on inquiry.

\section{Pruning}

For initial pruning, note "Planting Instructions" on Page 3, and also the information in planting leaflets sent with each shipment. The general rules of pruning fruit trees are: To avoid all crotches and leave the branches evenly distributed along the main stem. Prune so an evenly balanced head will result. Some shortening of the terminal growth on peaches is necessary, remembering that an open type head should be developed, and that pruning is a matter of judgment, the object in this case being to regulate the shape of the tree and to encourage the production of fruit spurs. For this reason the promiscuous sawing and dehorning of trees is not advised but rather a careful study of the fundamental features and then proceeding along that line.

\section{SPRAYING GUIDE}

S OגE persons have been disappointed in their results from spraying because they used the wrong material, failed to apply thoroughly, on did not apply at the right time. Therefore, to get results study the character of insects and pests and then the work can be done intelligently and profitably. No single application nor single spray material will control every trouble.

There are two general divisions of plant enemies, i. e., insect and fungus.

\section{INSECTS}

For convenience let us divide the insects in two groups: Chewing and sucking.

Chewing insects are those, like the potato beetle or codling moth, that eat part of the tissues of plants. This class is easily controlled by the spreading of some poison like Paris Green or Arsenate of Lead within their feeding range, provided it is done in time. Thorough application will soon control this class.

Sucking insects. This group have no jaws but proboscis, or beaks, that they sink into the tissues and suck out the sap. Scale or Aphis are familiar examples. Because of this character of feeding they are not susceptible to poison spread on the foliage so they must be killed with a contact-poison. These are either irritants or miscible oil combinations so that when they are hit with a spray material death will result. Because every insect must be touched to insure results, thoroughness is absolutely necessary in bad infestation.

\section{DISEASES}

Fungus causes most of the plant diseases. It spreads by means of spores which are very small, dust-like bodies that adhere to a congenial host plant and there develops its thread-like structures causing a diseased condition. They are easily spread from plant to plant by insects, birds, wind and water. Pecause this fungus growth develops at the expense of the host plant and leaves it in a diseased condition, prevention and cure are equally important. In spraying commence before the disease has advanced and spray thoroughly as spores will germinate rapidly on favorable host plants and in moist seasons.

\section{SOME BEST SPRAYING REMEDIES}

Arsenate of Lead-Is recommended for all chewing insects. It mixes readily, sticks to the foliage better, remains in suspension longer, not injurious to plants, is not an irritant, thus easy to apply. Use two to three pounds per fifty gallons of water, depending on the virility of the insect. First mix in a small quantity of water; strain, or at least see that it is free of lumps, and then mix thoroughly. Keep agitated when applying.

Bait for Cut-Worm or Grass Hoppers-Bran, 4 quarts: Arsenic or Paris Green, 3 oz.: Cheap Syrup, 1 pint; Water, 1 gallon. Mix thoroughly and scatter about infested areas. Do not put it where poultry, etc., will reach it.

Kerosene Emulsion-Hard Soap, Íf pound: Hot Water, I/2 gallon; Kerosene, 1 gallon. Slice soap anrl dissolve in hot water. Remove it from fire and pour in kerosene while still hot. Churn and pump into itself until a creamy emulsion is formed, which should mix witl cold water. For all sucking insects dilute eight to fifteen times.

Bordeaux Mixture-4-4-50 Mixture. Copper Sulphate, 4 pounds; Fresh Stone Lime, 4 pounds; Water, 50 gallons. Dissolve copper sulphate in hot water, using a wooden vessel. Slake lime in another receptacle. Slowly pour these into the water, stirring until an immaculate blue mixture results. It is ready for immediate use. Fresh mixtures give best results. Note Peach and Japan Plum foliage is tender and two pounds more lime is suggested. For all fungus, i. e., rots, moulds, mildews, etc., this is effective.

Lime Sulphur Solution-This is the commercial form and should not be confused with self-boiled lime sulphur. Standard commercial Lime Sulphur should test 32 degrees Baume by hydrometer.

Self Boiled Lime Sulphur-8-8-50. Slake 8 pounds of the best stone or lump lime in a barrel or tight box. Use hot water when available, but only enough to start slaking.

When slaking begins add $S$ pounds of flowers of sulphur (previously mixed to a paste with a small quantity of water) to the slaking lime, stirring constantly. Continue to add water in small quantities, sufficient to keep lime in soft, pasty condition.

As soon as the slaking is over (usually within fifteen minutes) it is important to add at once sufficient cold water to cool the mixture and stop the cooking of the sulphur. Stir vigorously and strain into spray barrel or tank, adding water to make 50 gallons of spray material.

\section{ASPARAGUS}

The Gardener's Favorite

A SPARAGUS is the earliest and best of all esculents and the easiest to grow if many old ideas are discarded. It is one of the most persistent of plants-tough as dock, but even dock can be killed over the same lines that cause people to fail with asparagus. There are two ways to grow asparagus. The owner of a town lot needs a bed five feet wide and as long as he wishes. Let it be made cream rich, spaded over, and three rows, eighteen inches apart, be drawn through it with a six-inch hoe, and say, four inches deep. Then the crowns should be spread out in these just as near like a spider as possible. Then let the earth be raked over and let this bed be kept clean and free from weeds for all time.

\section{RHUBARB}

Rhubarb, or pie plant, is known to everyone. Planted $4 \times 3$ feet with eye four inches below the surface on cream soil, success is assured. We offer only divided crown and not seedling plants as these are worthless.

Excelsior. Very early with long stem. Plant vigorous and dependable. 


\section{SMALL FRUITS}

\section{CURRANTS}

The Bountiful Producer

$\mathrm{T}$ HRIVES in deep soil and when properly manured and cultivated will yield bountiful returns. The insect enemy causing the most injury to the currant and gooseberry alike is a leat worm that can be killed by spraying the foliage with arsenate of lead or paris green as you do potatoes for the beetle. The pruning of the older plants conints in leaving a fair amount of the three and fouryear wood, an it is more productive of fruit. In planting, allow about four feet each way for development and prune in most of the top immediately after setting.

Fay's Prolific. One of the best reds and more largely planted than any other variety. When properly grown, this is a decidedly productive sort.

Black Naples. Valuable for jellies and jams; has a musky odor.

The white varieties have proven worthless in this climate.

\section{GOOSEBERRIES}

$\mathrm{V}$ ERY productive and are always in demand. When allowed to ripen they lose much of the sourness attributed to them because they are usmally offered to the public while green. Note pruning and cultural directions for currants. Plant $4 \mathrm{x}+$ feet, getting the earth well worked into the roots and firm. Prune off the tops to a few inches in order to assure growth.

Downing. Fruit almost round, large and juicy. Best quality. Whitish-green color. Does especially well in the North.

Houghton. Round, dark red when ripe; juicy, sweet 'Thin, smooth skin. Medium size. The bush is hardy, very productive, free from mildew and the best for general purposes in this section.

\section{BLACKBERRIES}

\section{Prolific and Easy to Grow}

I a state where wild blackberries are so plentiful one without experience would hesitate to plant blackberries. However, the cultivated varieties are so prolific, so easy of culture, that every garden should contain this fruit. The soil, to be ideal, should be a heavy type-clay loam. This so-called "poor man's fruit" if planted $6 \times 3$ feet will each year more than ray for the space it occuples. Many plant too close for best results. Topping in the young shoots just as they reach $3 r / 2-41 / 3$ feet to develop the side branches to fruiting condition is the only pruning required, save the removing of the old canes after they have produced a crop.

Early Harvest. Extra earliness and productivenes. make this the leading commercial and home variety. Is through with its crop when the wild ones begin to ripen. Hangs well onto the canes and is a money-maker.

Eldorado. A large oblong, conical berry, with small seed and core; sweet and juicy; hardy and productive.

\section{RASPBERRIES}

OOSE soils produce the best raspberries. Partial shade is no hindrance to productiveness as the natural habitat of the raspberries is in lower ground, filled with leaf mold and partly shaded. For this reason along higher fences and in between the young orchard trees, raspberries are likely to thrive. Allow not more than five good canes to develop to the plant and pinch out the tops of these when they attain a height of $21 / 2-3$ feet in order to encourage laterals.

\section{RED RASPBERRIES}

Cuthbert. Crimson, large, conical, firm and juicy. The canes are upright, strong and vigorous. Hardy. The standard late red market and home variety that is so popular and unsurpassed.

King. Bright scarlet, sweet and melting. This early red is the best of its season because of hardiness, productiveness and general good qualities. Ripens two weeks before Cuthbert.

St. Regis. The so-called everbearing. It does produce some berries throughout the summer and in the spring is an excellent producer. Quality very good.

\section{BLACKCAP RASPBERRIES}

Cumberland. Large, glossy, black, rather oval. Firm and stands handling well. After fruiting eight or ten new kinds we have come to the conclusion that no black raspberry of its season compares with it.

Kansas. The great market variety, more generally planted than any other kind; early, large, productive, round, firm, moderately juicy; a strong grower. Handsome appearance; stands shipping well.

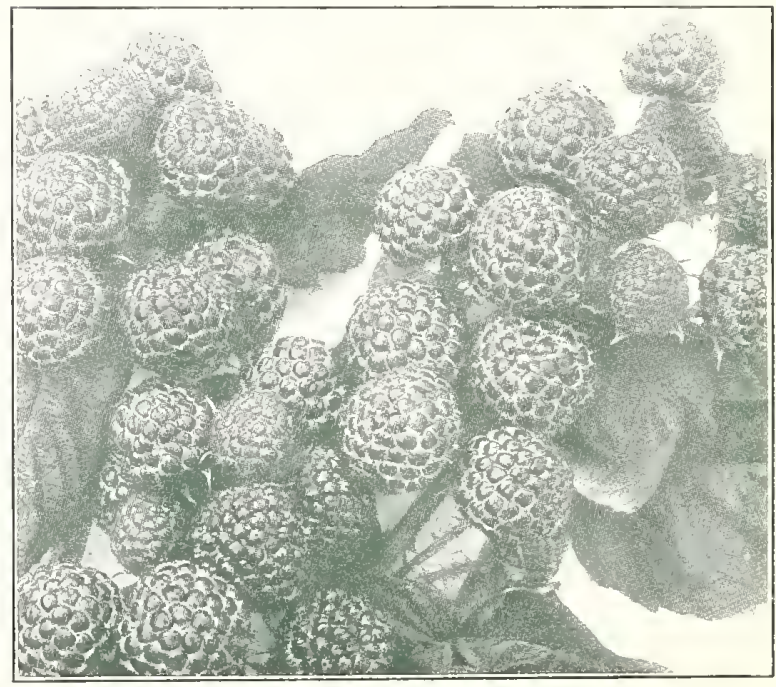

CUMBERLAND-THE LEADING BLACKCAP 


\section{QUICK REFERENCE LIST OF TREES AND PLANTS FOR SPECIAL PURPOSES}

\section{紫施造}

\section{FOUNDATION OR BASE PLANTING}

(Note descriptions for height)

Those Suited for "Front Line Planting"

Japanese Barberry

Spirea Thunbergii

Spirea Anthony Vaterer

Hypericum

Abelia

Deutzia gracilis

Globe Arbor Vite

Greek Juniper

Mugho Pine

Savin's Juniper

Pfitzer's Juniper

Yews

For Intermediate (4 to 6 Feet)

Spirea Van Houtte

Spirea Reeresii

Purple-leaved Barberry

Hydrangea

Golden Bell

Weigelas

Abelia

Calycanthus

Kerria

Snowberry

Arbor Vitze in variety

Retinispora in variety

Junipers in variety

Holly

Boxwood

Japanese Snowball

Taller Growing (For heavy planting or corners)

Tamarix aestivalis

Amoor River Privet

Regel's Privet

Viburnum Lantana

Althea

Mock Orange

Spirea Prunifolia

Loniceras

TREES THAT FLOWER

Catalpa

Dogwood

Red Bud

Horse Chestnut

Linden

Magnolia

Flowering (rab Apple

Japan Varnish
FOR STREET OR AVENUE PLANTING

Pin Oak

Sugar Maple

Norway Maple

Sycamore

European Linden

Elm

Ash

Lombardy Poplar

TREES FOR QUICK EFFECT

Ash

Catalpa

Russian Mulberry

Veeping Willow

Silver Maple

Lombardy Poplar

Sycamore

\section{WOODY PLANTS FOR}

PARTIAL SHADE

Boxwood

Hemlock

Junipers

Yews

Nugho Pine

Holly

Euonymus

Abelia

Barberry

Dogwood

Red Bud

Hypericum

Privets

Snowberry

Witch Hazel

Coralberry

Weigelas

Golden Bell

Snowball

Kerria

Calycanthus

Wock Orange

Rhodotypos

Aralia

\section{ATTRACTIVE OF BARK AND BERRY}

Snowberry

Coralberry

High Bush Cranberry

Red-twigged Dogwood

Euonymus

Barberry

Dogwood

Privets

Sumac

Wayfaring Tree

Bush Honeysuckle

Elder
FOR SCREEN PLANTING

(Note descriptions for height at maturity )

Lombardy Poplar

Willow

Practically all shade trees

Norway Spruce

Hemlock

Pines

Bush Honeysuckle

Altheas

Deutzia

Tock Orange

Snowball

Privets

\section{FOR DRY PLACES}

Junipers in variety

Mugho P'ine

Aralia

Barberry

Privets

Bush Honeysuckle

Yucca

Deutzia

Sumac

Coralberry

Ash

FOR MOIST PLACES

Birch

Maple

Sweet Gum

Sycamore

IVillow

Lombardy Poplar

lied-twigged Dogwood

Spirea Douglasil

Elder

$\mathrm{d}=\mathrm{h}$

Elm

()aks

Hemlock

Arbor Vitee

Snowball

Tamarix

Linden

Larch

PLANTS THAT COLOR IN THE FALL

Ash

Dogwood

Sweet Grum

Sugar Maple

Red Maple

Barberry

Snowball

() $)$ kes

Japan Varnish

Sumac

Spirea Prunifolia 


\section{N D E X}

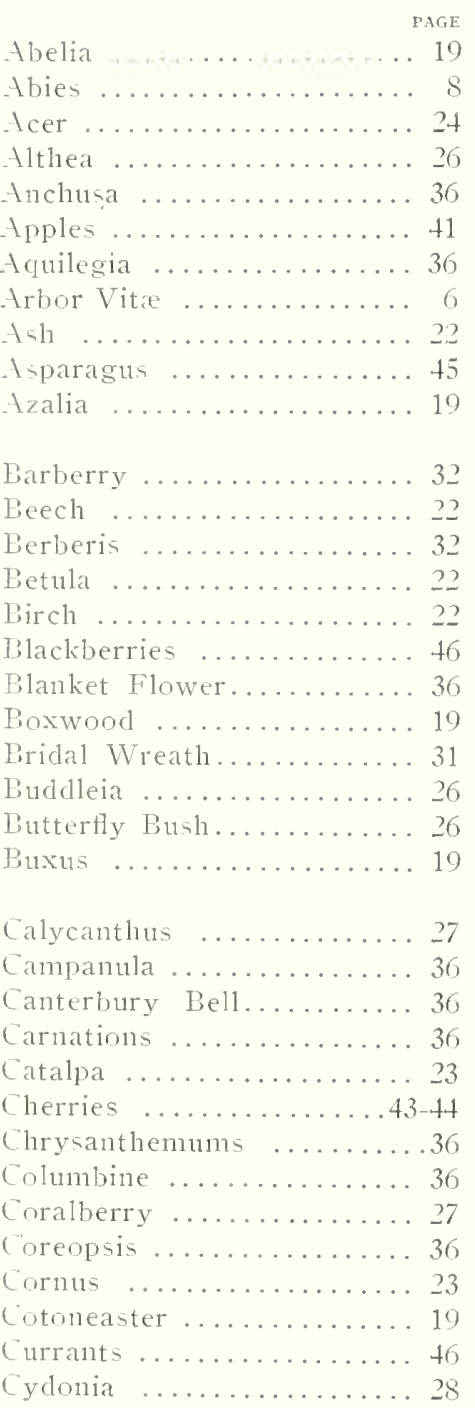

Deciduous Shrubs........26-31

Deciduous Trees........32-35

Delphiniums ........... 36

Deutzia ............... 27

Digitalis ............ 36

Dogwood ............. 23

Elder ................ 27

Elm $\ldots \ldots \ldots \ldots \ldots \ldots \ldots 23$

Euonymus .............. 19

Evergreens .......... 5-21

Fir ...............

Flowering Almond....... 26

Flowering Crab......... 27

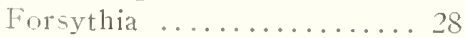

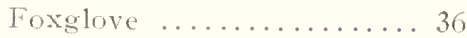

Fruit .............40-46

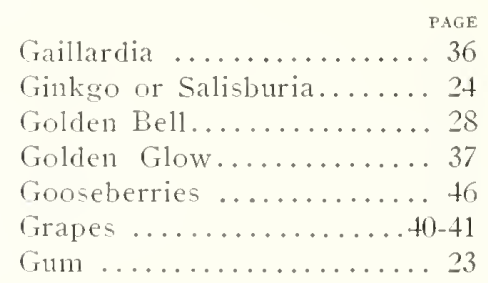

Hedge Plants........... 29-32

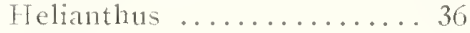

Hemlock ...............8-9

Hibiscus ........... 26-27

High Bush Cranberry...... 27

Holly ................. 19

Hollyhocks ............ 37

Honeysuckle, Bush......... 28

Horne Chestntit......... 23

Hydrangea ........... 28

Hypericum ........... 28

Ilex ................ 19

Iris ...............37-38

Japanese Bellflower....... 37

Japan Cypress............17

Japan Quince............28

Juniper .............11-13

Juniperus ..........11-13

Kentucky Coffee Tree.... 24

Larch .............. 24

Larix ................ 24

Ligustrum . . . . . . . 29-32

I ilac .............. 28

Linden .............. 24

Lonicera ..............28-29

Magrolia $\ldots \ldots \ldots \ldots \ldots \ldots .19$

Maiden Hair.............. 24

Mallow Marvels.......... 37

Maple .............. 24

Mock Orange............ 29

Morus ................. 25

Mulberry ............ 25

Oak.................25

Painted Daisy .......... 37

Peaches ...............43

Pearl Bush............ 28

Pears ................ 42

Pecans ............... 25

Peonies ................ 38

Perennials ..........26-28

Philadelphus ............. 29

Phlox .............. 37
PAGE

Picea ...............14-15

Pine ................13-14

Pinus ................ 13-14

Platanus .............. 25

Platycodon .............. 37

Plums ..............42

Poplar ................ 25

Poppies.............. 37

Populus ................ 25

Privet .............. 29-32

Pyrethrum ............. 37

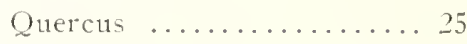

Quince ................4 4

Raspberries ............4 46

Red Bud ............. 25

Rer Hot Poker........... 37

Reference List............ 47

Retinispora ............ 17

Rhodotypos ............. 29

Rhubarb ............ 45

Rhus ................ 31

Rose of Sharon..........26

Koses .............. 33-35

Rudbeckia .............. 37

Salix ................ 25

Sambucus ............. 27

Shasta Daisies.......... 37

Shrubs .............26-31

Snowball .............. 29

Snowberry ............. 44

Spirea .............29-31

Strawberries .......... 44

Sumac ................. 31

Sunflower .............. 36

Sweet Shrub........... 27

Sweet William............37

Sycamore .............. 25

Syringa .............. 29

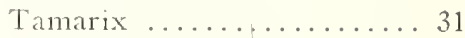

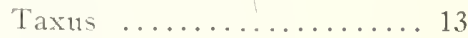

Thuya ............... 6

Tritoma .............. 37

Tsuga .............. 8-9

Viburnum ............. 31

Vines .................... 39

Wayfaring Tree......... 31

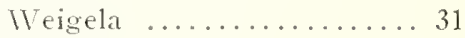

Willow ............... 25

Witch Hazel............ 31

Yew 


\section{ORCHARDIST SPRAYING CALENDAR \\ SPRAYING APPLES}

\begin{tabular}{|c|c|c|}
\hline Spray for & Time to Apply & What to Use \\
\hline 1. San Jose Scale. & $\begin{array}{l}\text { Dormant season; best time, just } \\
\text { before leaf buds open. }\end{array}$ & $\begin{array}{l}\text { Standard lime-sulphur, liquid, } 1 \text { gal. to } 8 \text { gals. water. } \\
\text { Scalecide or equivalent }\end{array}$ \\
\hline $\begin{array}{l}\text { 2. Apple Scab. } \\
\text { Apple Aphis. }\end{array}$ & $\begin{array}{l}\text { Just before blossoms open; when } \\
\text { showing pink color. }\end{array}$ & $\begin{array}{l}\text { Lime-sulphur, } 11 / 4 \text { gals, to } 50 \text { gals, water. Nicotine } \\
\text { sulphate, } 1 / 2 \text { pt. added to above if Aphis is present. }\end{array}$ \\
\hline $\begin{array}{l}\text { 3. Apple Worm (Codling Moth). } \\
\text { Apple Scab. }\end{array}$ & When blossoms have fallen. & $\begin{array}{l}\text { Lime-sulphur, } 11 / 4 \text { gals. to } 50 \text { gals. water and } 11 / 4 \mathrm{lbs} \text {. } \\
\text { arsenate of lcad powder. }\end{array}$ \\
\hline $\begin{array}{l}\text { 4. Apple Blotch. Apple Scab. } \\
\text { Codling Moth (Late Hatched). }\end{array}$ & Two weeks after blossoms fall. & $\begin{array}{l}\text { Bordeaux mixture } 3 \cdot 4-50,17 / 4 \text { lbs, arsenate of lead } \\
\text { powder. }\end{array}$ \\
\hline 5. Blotch. Apple Scab. Rots. & Two weeks after Spray No. 4. & Bordeaux mixture alone. \\
\hline $\begin{array}{l}\text { 6. Apple Blotch. Rots. Codling } \\
\text { Moth may be present. }\end{array}$ & $\begin{array}{l}\text { Two weeks after Spray No. } 5 . \\
\text { About June } 15 \text { th. }\end{array}$ & Bordeaux mixture $3-4-50,11 / 4$ lbs. arsenate of lead. \\
\hline $\begin{array}{l}\text { 7. Codling Moth. } \\
\text { Apple Blotch. Rots. }\end{array}$ & About July 15 th. & Bordeanx mixture $3 \cdot 4-50,11 / 4$ lbs. arsenate of lead. \\
\hline
\end{tabular}

\section{SPRAYING PEACHES AND PLUMS}

\begin{tabular}{|c|c|c|}
\hline Spray for & Time to Apply & What to Use \\
\hline $\begin{array}{l}\text { 1. San Jose Scale. } \\
\text { Leaf Curl. }\end{array}$ & Dormant season. & $\begin{array}{c}\text { Commercial lime-sulphur, } 1 \text { gal. to } 8 \text { gals. water. } \\
\text { Scalecide }\end{array}$ \\
\hline 2. Curculio. & After blossoms fall. & $\begin{array}{l}1 \text { lb. arsenate of lead powder, } 3 \text { lbs. lime, } 50 \text { gals. } \\
\text { water. }\end{array}$ \\
\hline $\begin{array}{l}\text { Peach Scab. } \\
\text { Brown Rot. Curculio. }\end{array}$ & $21 / 2$ to 3 weeks after Spray No. 2. & $\begin{array}{l}\text { Self-boiled lime-sulphur } 8-8.50,1 \text { pound arsenate of } \\
\text { lead powder. }\end{array}$ \\
\hline $\begin{array}{l}\text { 4. Brown Rot. } \\
\text { Scab. }\end{array}$ & 3 to 4 weeks after Spray No. 3. & Self-boiled lime-sulphur 8-8-50. \\
\hline $\begin{array}{l}\text { 5. Brown Rot. } \\
\text { Scab. }\end{array}$ & $\begin{array}{l}\text { About } 4 \text { weeks before fruit } \\
\text { ripens. }\end{array}$ & Self-boiled lime-sulphur 8.8-50. \\
\hline
\end{tabular}

A Table Showing the Number of Trees or Plants to the Acre by the Square System.

\begin{tabular}{|c|c|c|c|c|c|}
\hline \multicolumn{2}{|c|}{ Distance } & & & \multicolumn{2}{|c|}{ No. of Trees } \\
\hline 1 & foot & apart & each & way & 43,560 \\
\hline 2 & feet & "6 & & 6 & 10,89 \\
\hline 3 & " & " & “ & "6 & 4,84 \\
\hline 4 & $\because$ & " & " & "i & 2,722 \\
\hline 5 & $"$ & " & «i & “ & 1,74 \\
\hline 6 & $"$ & $"$ & $"$ & " & 1,21 \\
\hline 7 & $" 6$ & " & $"$ & " & 8 \\
\hline 8 & $\because$ & 6 & is & $" 4$ & \\
\hline 9 & $" r$ & 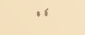 & $" 6$ & $"$ & \\
\hline 10 & si & $"$ & 66 & "6 & 4 \\
\hline 11 & $\because$ & $"$ & " & $" 6$ & 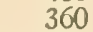 \\
\hline 12 & 6i & "6 & $" 6$ & $" 6$ & \\
\hline 13 & " & 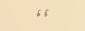 & $"$ & " & 25 \\
\hline 14 & $\because$ & ir & $" 6$ & " & 22 \\
\hline 15 & “6 & " & is & “ & \\
\hline 16 & $\because$ & $s$ & or & 6 & 1 \\
\hline 17 & 66 & $" 6$ & 6 & 66 & \\
\hline 18 & $"$ & $"$ & $"$ & $"$ & 1 \\
\hline 19 & $" 6$ & 6 & 6 & $" 6$ & 1 \\
\hline 20 & $" s$ & $" 1$ & " & 6 & 1 \\
\hline 25 & “ & 16 & 66 & 16 & \\
\hline & " & ur & $"$ & ir & \\
\hline 35 & 66 & " & " & " & \\
\hline 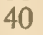 & " & $"$ & “ & " & \\
\hline
\end{tabular}

\section{DISTANCES FOR PLANTING}

Standard Apples ................40 feet apart each way Standard Pears and Strong

Growing Cherries ...........20 feet apart each way Duke and Morello Cherries ...........18 feet apart each way Standard Plums, Peaches, Apricots and Nectarines .....16 to 18 feet apart each way Dwarf Pears, Dwarf Apples and Quinces ............... 10 to 12 feet apart each way Grapes ........ Rows of 10 to 16 feet apart; 7 to 16 feet in rows Currants and Gooseberries ................. feet apart Raspberries and Blackberries .........3 to 4 feet by 5 to 7 feet Strawberries, for field culture ........... 3 by $3 \mathrm{r} / 2$ feet Strawberries, for garden culture .......... to 2 feet apart Asparagus, in beds .................... by $1 \frac{1}{2} 2$ feet Asparagus, in fields .................. by 3 feet

Rule-Multiply the distance in feet between the rows by the distance the plants are apart in the rows and the product will be the number of square feet for each plant or hill; which divided into the number of feet in an acre $(43,560)$, will give the number of trees to an acre. 
